\title{
Ritual and Ceremony in the Spanish Royal Chapel, c. 1559-c. 1561
}

\section{Bernadette Nelson}

Early Music History, Vol. 19. (2000), pp. 105-200.

Stable URL:

http://links.jstor.org/sici?sici=0261-1279\%282000\%2919\%3C105\%3ARACITS\%3E2.0.CO\%3B2-G

Early Music History is currently published by Cambridge University Press.

Your use of the JSTOR archive indicates your acceptance of JSTOR's Terms and Conditions of Use, available at

http://www.jstor.org/about/terms.html. JSTOR's Terms and Conditions of Use provides, in part, that unless you have obtained prior permission, you may not download an entire issue of a journal or multiple copies of articles, and you may use content in the JSTOR archive only for your personal, non-commercial use.

Please contact the publisher regarding any further use of this work. Publisher contact information may be obtained at http://www.jstor.org/journals/cup.html.

Each copy of any part of a JSTOR transmission must contain the same copyright notice that appears on the screen or printed page of such transmission.

JSTOR is an independent not-for-profit organization dedicated to and preserving a digital archive of scholarly journals. For more information regarding JSTOR, please contact support@jstor.org. 


\section{RITUAL AND GEREMONY IN THE SPANISH ROYAL CHAPEL, C.1559-C.1561*}

Day of St Matthias, on his birthday, His Majesty offers as many coins as years as he has attained, and [one] more for the year in which he has entered; the King Our Lord does the same on the twenty-first of May. ${ }^{1}$

On the abdication of his father Charles V from the Spanish throne in 1556, Philip II was to inherit probably the most important and prestigious court chapel in Europe. ${ }^{2}$ Its history, structure and musical eminence were well established during the time of the Burgundian dukes in the fifteenth century, under whose patronage some of the most prominent musicians and composers found

* I wish to thank the following people for kindly commenting on an earlier version of this study and for making suggestions for improvements: Juan Carlos Asensio, Bonnie Blackburn, Barbara Haggh, Tess Knighton, Michael Noone and Luis Robledo, and Kirstin Kennedy for checking my transcriptions of the royal chapel documents in the Biblioteca da Ajuda in Lisbon.

The following abbreviations are used:

B-Agr Brussels, Archives Générales du Royaume

E-Mn Madrid, Biblioteca Nacional

E-Mpa Madrid, Palacio Real

E-Sag Simancas, Archivo General

F-Pn Paris, Bibliothèque Nationale de France

GB-Ob Oxford, Bodleian Library

P-La Lisbon, Biblioteca da Ajuda

P-Ln Lisbon, Biblioteca Nacional

1 'Dia de Sancto Mathia por su nascimento offrece Su Magestad tantos ducados quantos annos cumple, y más el anno en que entra; esto mismo haze El Rey Nuestro Señor a viente y vno del Mayo'; La Orden que se tiene en los Officios en la Capilla de Su Magestad ( $\mathrm{P}$ La 51-VI-37), fol. 68v. A full transcription of the document is included as Appendix 3.

2 Studies on Gharles V's court chapel include chapters in E. Vander Straeten, La Musique aux Pays-Bas avant le XIX ${ }^{e}$ siècle, 8 vols. (Brussels, 1867-88; repr. New York, 1969, ed. E. Lowinsky); H. Anglés, La música en la Corte de Carlos V, i (Barcelona, 1944, repr. 1984); J. Schmidt-Görg, Nicolas Gombert, Kapellmeister Karls V: Leben und Werk (Bonn, 1938); and B. Bouckaert, 'The Capilla Flamenca: The Composition and Duties of the Music Ensemble at the Court of Charles V, 1515-1558', in The Empire Resounds: Music in the Days of Charles $V$, ed. F. Maes (Leuven, 1999), pp. 37-45. 
their livelihood; as an institution, it was also partly indebted to traditions and an infrastructure inherited from the Castilian court of Ferdinand and Isabella which was passed on to Charles V following the death of Ferdinand in 1516. When Philip II came to power, the amalgamation of his own court and chapel with that of the Emperor resulted in an organisation of unheard proportions, even though many officers of the Imperial court were to accompany Charles $\mathrm{V}$ on his retirement to the monastery in Yuste, in Spain, and others of Philip's own train were to return independently to their homeland on periods of extended leave. This was evidently a time of considerable upheaval, during which membership fluctuated and the structural organisation necessarily underwent a period of some adjustment. Before Philip II finally returned to Spain from the Netherlands in September 1559, and during the succeeding years embracing the establishment of the court in the royal Alcázar, Madrid, in May 1561, measures were taken to stabilise the institution during a period of almost relentless political and religious activity which marked the times: certainly in the royal chapel itself there is evidence that efforts were made to account for this changeover of sovereignty, and while no new statutes seem to have been drawn up at the beginning of Philip's reign, many statutes and other constitutional documents primarily dating from Charles V's time were redrafted and reinstated. ${ }^{3}$

3 For a synopsis of the historical circumstances leading to Philip II's inheritance, and the impact these influences had on the court, see L. Robledo Estaire, 'La música en la corte Madrileña de los Austrias. Antecedentes: las Casas Reales hasta 1556', Revista de musicología, 10 (1987), pp. 753-96. A graph demonstrating 'la evolución de las Casas Reales' from the time of Ferdinand and Isabella to that of Philip II is included on pp. 794-5 (Table V). See also L. Robledo, 'La música en la corte de Felipe II', in Felipe II y su Epoca, Actas del Simposium, San Lorenzo del Escorial, 1/5-IX-1998 (El Escorial, 1999), pp. 141-67. Concerning the Castilian royal chapel during the time of Ferdinand and Isabella, see T. Knighton, 'Ritual and Regulations: The Organization of the Castilian Royal Chapel during the Reign of the Catholic Monarchs', in E. Casares and C. Villanueva (eds), De Musica Hispana et aliis: miscelánea en honor al Prof. Dr José López-Calo (Santiago de Compostela, 1990), pp. 291-320. Several documents of the royal chapel were transcribed by the historian and archivist Francisco Asenjo Barbieri. These papers, now preserved in the Biblioteca Nacional in Madrid (E-Mn), have recently been edited (though not without error) as a two-volume collection by Emilio Casares: Francisco Asenjo Barbieri: Documentos sobre música española y epistolario (Madrid, 1986-8). The documents of the royal court are included in vol. 2. In the present study, this collection will henceforth be referred to as 'Barbieri papers 2', followed by the number of the document ('doc.') cited. See also below, 'Statutes of the royal chapel'. I would like to thank Michael Noone for making available to me the latter and numerous other books and articles for the preparation of this study. 
Ritual and Ceremony in the Spanish Royal Chapel, c.1559-c.1561

This study centres on a newly discovered constitutional document of the Capilla Real which was drawn up for the Imperial chapel most probably in about 1550 , but which was slightly adapted on Philip II's accession to the throne, and certainly after September 1559. ${ }^{4}$ Entitled La Orden que se tiene en los Officios en la Capilla de Su Magestad ('The Order which is held in the Offices in the Chapel of His Majesty'), the text largely consists of a record of procedure, ceremony and matters of protocol in the Spanish royal chapel, the main body of which was apparently written by a certain Aguirre, who is identified as 'chaplain of His Majesty, and receiver of his Chapel' ('Capellan de Su Magestad, y Receptor de su Capilla'). ${ }^{5}$ Having been written by an active member of the chapel, the document often offers insight into practices and ceremonial traditions which have eluded the majority of formal statutory edicts. Woven into details of liturgical ritual of a more everyday nature - the lists of occasions for sermons, offerings and processions, for instance - are glimpses of what can only have been long-standing practices inherited from the Burgundian court of Philip the Fair, Charles V's immediate predecessor, as well as customs associated with important anniversaries dating from Charles V's time itself: these include the procession of knights holding lighted candles during mass at chapter meetings of the Order of the Golden Fleece, an allusion to ceremony on the feast day (29 September) of the Order of St Michael, when the robes of that order were worn, ${ }^{6}$ the offering by the king of a gold coin and a lighted candle in which was embedded un escudo (a gold coin bearing the royal coat of arms) during mass for commemorations of members of the royal family such as the Empress Isabella, and the offering at mass on the anniversary of the Emperor's birthday

4 Among the amendments are clauses indicating Philip's status as monarch, as well as a reference to observances on each anniversary of the death of his father, the Emperor Charles V, which occurred on 21 September 1558.

La Orden, fol. 77.

6 This reference to the French Order of St Michael, which was founded by King Louis XI in 1469, is unusual within Burgundian-Habsburg court documents. Although the Order was only established at that time, a chapel dedicated to St Michael had been founded in the Sainte-Chapelle in Dijon in 1452, the court of the Burgundian dukes and of the Order of the Golden Fleece from 1432. There was a close association between these two Orders and the statutes of that of St Michael were in fact modelled on those of the Golden Fleece. See B. Haggh, 'The Archives of the Order of the Golden Fleece', Journal of the Royal Musical Association, 120 (1995), pp. 1-43, at pp. 36-7. 
and coronation (again by the king) of a bag of gold coins. Only some of this more contextual evidence is clearly stated, however: it is often only through the process of the unmeshing of a series of oblique and dislocated references that the significance of some details in La Orden emerges more strongly, particularly when they can be linked with descriptions and accounts found in chronicles and other historical documents from the era. Further, La Orden provides insight into liturgical acts and ceremonies in which the choreography is sometimes intimately linked with the timing of musical items - an aspect which is unique among constitutional documents and which has considerable bearing on appropriate contexts for the performance of sacred vocal polyphony. It is also possibly the earliest royal chapel document to give evidence of the use of violones in the accompaniment of vocal music, and one of the few to give a reference to the interaction of organ music with polyphony.

\section{$L A$ ORDEN: CONTEXT AND DATING}

A Miguel Pérez de Aguirre is clearly documented in Spanish archival sources as receptor in Charles V's chapel in 1548, 1550 and $1552,{ }^{7}$ which therefore provides a specific context for the origin of the document, if not an almost exact date. We learn of his probable authorship through the acknowledgement provided by an unknown recipient which in full reads, 'This account was given to me by Aguirre, Chaplain of His Majesty and receiver in his Chapel. ${ }^{9}$ Judging from Aguirre's final statement, it seems likely that the recipient had requested of him an account of procedures in the royal chapel and that this was made after the court had settled in Spain. Here, while saying that what he has written reflects present-day customs in the royal chapel, Aguirre also indicates that variations occur according to context and circumstance, and that therefore a number of 'diverse ceremonies' can be found in the

7 I am most grateful to Luis Robledo for providing me with this important information about Aguirre's activities in Charles V's chapel. These dates correpond with a series of pay documents in Aguirre's name preserved in the Archivio de Simancas (Casas y Situos Reales, leg. 92). One made out to his heirs in 1561 indicates that Aguirre had died on 24 August the previous year.

8 'Esta rellacion me dió Aguirre, Capellan de Su Magestad y Receptor de su Capilla', La Orden, fol. 77. 
royal chapel in Spain. It is possible that this particular statement may reflect more his long experiences as chaplain in the Imperial royal chapel; on the other hand, it does show his awareness of rituals and ceremonies peculiar to the royal institution:

This [the foregoing account] is that which is customary at present, and is observed in His Majesty's chapel; however, it [the order of things] has been varied in some way with the times and places where His Majesty travels, and thus we see that with the royal chapel in Spain there are some diverse ceremonies. ${ }^{9}$

Aguirre's position both as chaplain and receptor in the royal chapel would inevitably have some bearing on the bias of the document and the question of which issues receive more attention. His was an ancient and extremely responsible post, the origins of which lay in the Spanish royal chapel of the Catholic Monarchs. ${ }^{10}$ According to this tradition, a receptor's role was a high-ranking and all-embracing one which ranged from being responsible for organising mass rotas and for taking account of all absences among chapel members, to the collecting of fines and the distribution of fees and collections. In the portion of the document devoted to the various officers of the chapel and their duties, Aguirre outlines the responsibilities of a receptor much along the lines (though in less detail) of those found in the early fifteenth-century set of constitutions for the Castilian royal chapel: ${ }^{11}$

The receiver of the chapel receives and administers all the distributions offered as admission duty, offerings, legitimations or whatever else he has to distribute.

In the absence of the first chaplain (capellan mayor), or his deputy (lugar teniente), the receiver recommends which prelate and chaplains should go and take the Office.

On Sundays and [major] feasts, the receiver accompanies the prelates who are to offer the 'Gospel' and the pax to the celebrants [to be kissed]. ${ }^{12}$

9 'Esto se acostumbra al prezente, y se guarda en la Capilla de Su Magestad, pero ha se variado en alguna manera con los tiempos, y lugares por dó Su Magestad anda, y ansy vemos que en España con la Capilla Real hay algunas ceremonias diversas'; La Orden, fols. $76^{\mathrm{v}}-77$.

${ }^{10}$ See Knighton, 'Ritual and Regulations', p. 300.

1 Constituciones de la Real Capilla de Don Henrique IV, ed. Barbieri papers 2, doc. 124.

12 This evidently refers to the custom of offering the Missal and the plaquette (the pax) to be kissed after the reading of the Gospel and after the Agnus Dei respectively. (See La Orden, fol. $63^{v}$.) 


\section{Bernadette Nelson}

The receiver is responsible for assigning the [occasions] for sermons, the weekly masses and other offices of the chapel [to the chaplains]. ${ }^{13}$

The receiver is responsible for advising the chaplains; when there are any extraordinary offices in the chapel the receiver takes distributions for [the equivalent] of two chaplains. ${ }^{14}$

Aguirre is quite explicit about this question of distributions (destribuciones) and, at a later point and with specific reference to the singers of the chapel, he provides more detail on the relationship between the paying of an entrance fee and the receiving of distributions. He relates how all new chaplains admitted to His Majesty's services should pay the 'receiver' 3,000 reis $^{15}$ as entrance fee and how, like the chaplains, but excepting the maestro de capilla, the clerks and the boys, all singers of the chapel should also pay this fee. ${ }^{16}$ In keeping with traditions of the Spanish chapel of the Catholic Monarchs, the receptor in Charles V's chapel witnessed the taking of an oath of allegiance of new chapel members before the capellan mayor, head of the chapel. If, in assessing this document, we take into account the role of Aguirre in the royal chapel as chaplain and receiver, then a more precise context can be given for its apparent emphasis on such issues as offerings, the allocation of gifts and distributions, occasions for preaching sermons, the ceremonies of the Gospel blessing and the kiss of the pax.

${ }^{13}$ In the section immediately following, which concerns the responsibilities of the chaplains, it is written: 'Unless there is a legitimate reason, no chaplains can excuse themselves from serving [at the Offices] of their week of duty and which were recommended to them by the receptor'; La Orden, fol. $74^{v}$. This particular responsibility of the receptor was also stipulated in the Constituciones of Henry IV (c. 1436) and that of the Catholic Monarchs. See Barbieri papers 2, docs. 124 (item 9) and 126 (item 8). For further information on these specific duties, see below, p. 131.

${ }_{14}$ La Orden, fols. $73^{v}-74$.

15 A similar amount was also stipulated in the earlier Constitutiones de la Capilla Real (item 20). See Barbieri papers 2, doc. 126. A number of these stipulations, including the payment of an entrance fee, are also familiar in such institutions as the sixteenth-century papal chapel. See R. Sherr, 'A Curious Incident in the Institutional History of the Papal Choir', in R. Sherr (ed.), Papal Music and Musicians in Late Medieval and Renaissance Rome (Oxford, 1998), p. 192, where he refers to this occurrence in the 1545 Constitution of Pope Paul III. See also ibid., p. 188, n. 5, for sources for modern transcriptions of this papal document.

16 'Entradas de Capellanes. Todos los Capellanes de Su Magestad primero que tomen sobrepellis ó le admitan en la Capilla, quando entran de nuevo han de hazer la solemnidad del Juramento ante el Capellan Mayor, y el Receptor, y pagan al Receptor tres mil reis de entrada para toda la Capilla. ... Todos los Cantores y officiales de la Capilla, se quisieren ganar destribuciones han de pagar la entrada como vn Capellan excepto el Capellan Mayor, y los mozos y los niños'; La Orden, fols. 76 and $76^{\mathrm{v}}$. 
As Aguirre died in August 1560, the document as a testimony of practices in Philip II's chapel in Spain (see quotation above) theoretically can only have passed hands sometime between late 1559 and the summer of 1560 , a vital period when Philip and his court, though primarily stationed in Toledo at the royal Alcázar, were engaged in the numerous political and religious disturbances which shook Spain at the time. On Philip's arrival in Valladolid in September 1559 he immediately became involved in affairs of state and the drastic measures instigated by the Inquisition, presiding over his first auto da fe in Valladolid in early October. It was also during this period of unrest that Philip married Elizabeth de Valois (on 31 January 1560) and began to make plans for the building of the royal Jeronymite monastery of El Escorial and also to look for an alternative royal residence for his court; the court eventually moved from Toledo to the royal Alcázar in Madrid in May 1561. ${ }^{17}$ It is possible therefore that the recipient had recently assumed new responsibilities in the chapel (perhaps even as receptor himself), thus coinciding with Philip's return to Spain, and was anxious to become acquainted with details of ceremony and procedure; he certainly shows his awareness of the possible implications of the changeover of sovereignty. ${ }^{18}$ For instance, after stating that he had received the account from Aguirre, he notes that there is another Relacion in the hands of the contralor, written in French, which recounts how to serve the chapel in the Burgundian manner' ('al uzo de Borgoña'); ${ }^{19}$ then immediately following this statement is what appears to be a direct copy of a paragraph from the set of statutes originally issued by Charles $\mathrm{V}$ for the Spanish royal chapel in $c .1518$ (see below) which lists a number of feast days on which sermons should be preached in the chapel, preceded by the rider that these are the occasions for sermons if one keeps

17 For an outline of events during this period, see H. Kamen, Philip of Spain (New Haven and London, 1998), pp. 79-81 and 179-82. For an account of the history of El Escorial, see M. J. Noone, Music and Musicians in the Escorial Liturgy under the Habsburgs, 1563-1700 (Rochester, NY, 1998).

18 The names of the receptors during this period have not been traced, though one is mentioned in a document dating from 1562 (see Barbieri papers 2, doc. 156).

19 La Orden, fol. 77. The office of the 'contralor' ('controller' or 'inspector') was as general mediator in the section of the royal court administered by the 'House of Burgundy'. See Robledo, 'La música en la corte de Felipe II', p. 142. 
[the customs in the chapel] of his father ${ }^{2}{ }^{20}$ The remainder of the addendum to Aguirre's text appears to have been added over a relatively short period between the feast of the Purification and Ash Wednesday, being largely concerned with the procession and other rituals on both these days, mentioning that it was usual for the king to celebrate the feast of the Purification at a monastery. In this section, his concern about the correct days for sermons during the Lenten season again indicates his responsibility in this regard: 'On passing Septuagesima Sunday one should consult with His Majesty regarding the Order that he requires for all the sermons during Lent so as to inform the preachers. ${ }^{21}$

From the contextual point of view, one of the most significant details in the addendum occurs after the description of the distribution of the ashes on Ash Wednesday. In connection with the question of the ritual of the Gospel blessing and the kiss of the pax, the text mentions five living members of the royal family: the King, the Queen, the Princess, the Prince and, by name, Philip's half-brother Don Juan de Austria. Curiously, this passage implies that Don Juan may have been excluded from certain royal privileges. The text relates that the Gospel and the pax were to be offered to the King, the Queen, the Princess, and the Prince; however, they were not to be offered to Don Juan even though he was apparently present in the King's canopy: 'The pax and the Gospel are offered to the King, the Queen, Prince and Princess; nothing is served to Don Juan de Austria even though he occupies just a small textiled chair without a cushion within the canopy. ${ }^{22}$ The precise implications of this passage are at present obscure, yet it does help towards dating this particular section of the document. The prince referred to here could either have been Don Carlos, who died in 1568, or Alessandro Farnese, son of Margaret of Parma (Philip's half-sister) who was at court with Don Carlos and Don

20 'Ver Capitulo zerca de los sermones que ha de haver en la Capilla de Su Magestad, si se guarda lo que en la de su padre'; La Orden, fol. 77. The clause listing the sermons was copied directly from Charles V's Estatutos de la Capilla del Emperador Carlos quinto al vzo de la Caza de Borgoña (clause [10]), a copy of which immediately succeeds La Orden que se tiene in P-La 51-VI-37, fols. $79^{\mathrm{v}}-83^{\mathrm{v}}$. The text is edited below in Appendix 4 . I am most grateful to Kirstin Kennedy for deciphering this phrase, which has thrown very important light on the circumstances of the transmission of La Orden in c. 1560.

${ }^{21}$ La Orden, fol. $78^{\mathrm{r}-\mathrm{v}}$.

22 Ibid., fol. 79. 
Juan during this period, first in Toledo and then in Madrid ${ }^{23}$ Don Juan was only infrequently at court after the mid-1560s, and so it is likely that the Queen was Elizabeth de Valois (who also died in 1568), and the Princess the King's sister Juana, who spent much time at court following the termination of her regency in 1559 . (She died in 1573, Don Juan in 1578.) The identity of the Prince, however, is difficult to determine, but Don Carlos began to have troubles with his health in $c$. 1561-2, which makes it less likely that he would have been regularly in chapel with his family after this time. It seems reasonable to propose, therefore, that the addendum was written more or less at the time the document reached the hands of Aguirre's recipient in $c .1560$ and that the period covered here, from the feast of the Purification (2 February) to the beginning of Lent on Ash Wednesday, actually reflects specific occasions either in early 1560 or, most probably, in early 1561 . In all events, it was certainly penned before the mid-1560s.

Unfortunately, like so many other royal chapel documents, ${ }^{24}$ the original version of La Orden is not known to have survived. The copy which comes down to us dates only from about the midseventeenth century, and is one of a series of documents apparently originating in Spanish and Portuguese courtly circles which were copied around the same time and bound together in a single volume with consecutive foliation. ${ }^{25}$ As it is written in a uniform hand, there is some difficulty in deciphering the different layers and assessing their precise historical chronology. Significantly, La Orden is immediately succeeded in this volume by a copy of the previously untraced set of statutes drawn up by Charles V in Spain towards the beginning of his reign in $c .1518$ entitled Estatutos de

23 See Kamen, Philip of Spain, pp. 89 and $134 \mathrm{ff}$.

24 The copies of royal chapel documents made by Barbieri, for instance, and which now form the basis of the so-called Barbieri papers (see above, n. 3), are in most cases all that we have of this important series. When taking these documents into consideration, one cannot always be certain as to which passages constituted part of an original document, which passages or phrases may have been lifted from others, and which may have been edited and transformed or even miscopied. This of course poses problems for their dating and chronology.

25 P-La 51-VI-37. The volume as a whole includes copies of a number of official court documents, including notices, letters, regulations, and also copies of Wills of members of the Spanish royal family. It was probably copied in Portugal (a number of orthographical details indicate that the copyist was Portuguese), and is one of several such volumes now preserved in the Biblioteca da Ajuda. 
la Capilla del Emperador Carlos quinto al vzo de la Caza de Borgoña ('Statutes of the chapel of the Emperor Charles V according to the use of the House of Burgundy'), and a further mandate issued by the Emperor concerning the ways in which his court was to be organised. ${ }^{26}$ The statutes were to become the model for a document also drawn up shortly after Philip II's return to Spain (see below); it is possible, therefore, that at least La Orden and a copy of the Estatutos were kept together, serving as reference to the receptor and other members of the royal chapel in the 1550 s and 1560 s.

\section{STATUTES OF THE ROYAL GHAPEL}

The familiarity of the Spanish royal court with Burgundian ceremonial and etiquette since about 1548, when it was officially adopted during Prince Philip's regency (though not without some resistance by the Castilians), and Philip's personal agreement to follow his father's ideas on courtly procedure, were factors which contributed to the already 'Burgundian mode' which flavoured the court prior to his accession to the throne. ${ }^{27}$ Further, just before Charles's abdication, Philip promised to maintain the structure of the Imperial chapel completely ${ }^{28}$ and, certainly as regards structure and ceremony, there is every evidence to suggest that Philip's chapel was indeed modelled on that of his father. This would explain the context for at least one other important document dating from the first years of Philip's return to Spain which is clearly derived from the Estatutos. It is likewise headed Constituciones o estatutos de la Real Capilla de S. M. el Emperador Carlos $V$ al uso de la Casa de Borgoña, but, as an indication of its new function and status,

${ }^{26}$ Ordem e firma que o Emperador Carlos $5^{\circ}$ teve em o servico da sua Camara, P-La 51-VI-37, fols. 85-93.

27 See Robledo, 'La música en la corte Madrileña', pp. $771 \mathrm{ff}$. , where he discusses the implications for Philip's court of the Etiquetas de Palacio de 1545 of Charles V and the new set of instructions drawn up in August 1548 regarding the change of etiquette. From that time, Philip's royal household increased greatly in size and was divided into five parts, of which one was the chapel, each headed by its own administration. For details of the chapel ordinances of 1545 , see Appendix 2. See also Kamen, Philip of Spain, pp. 34-5 and 194-5.

${ }_{28}$ See M. J. Noone, 'Philip II and Music: A Fourth Centenary Reassessment', Revista de musicología, 21 (1988), pp. 431-51, at p. 446. For further indications of the influence of Charles V on his son, see idem, Music and Musicians in the Escorial Liturgy, pp. 26-31. 
it is subtitled Estatutos que hasta agora se han guardado en la Capilla Imperial y se han de observar en la Real Capilla de su S.M. conforme al uso de Borgoña ('Statutes which were observed in the Imperial chapel until now, and which should be observed in His Majesty's Royal Chapel according to the Burgundian manner'). ${ }^{29}$ In this text, the directives originally issued by the monarch are refashioned so as to read in the third person, and details of some of the issues are slightly expanded. Further, we find that the term for the Flemish chapel, capilla flamenca, had originally been described as 'Our Chapel of our States of Flanders' ('Nuestra Capilla de Nuestros Estados de Flandes'), and that the titles of a few chapel officers were adapted.

The recovery of a copy of one of the original versions of Charles V's Estatutos means, for the first time, that those reissued during Philip II's time can be placed in a more specific historical context and that a more thorough investigation into their content and contextural significance is now possible. Also, some attempt can be made in tracing their lineage through earlier constitutional texts. The very fact that the essence of the text remains the same, about forty years after the original drafting of the document, does imply the intended continuance of ceremonial practice and chapel regulations, in keeping with Philip's desire to respect long-established traditions. In outline, Charles V's Estatutos classify the hierarchy of chapel members under the headship of the limosnero mayor (first almoner). It specifies that, from thenceforth, offices were to be celebrated according to 'Roman custom and usage', and it gives important details such as the times of sung mass and the occasions when sermons were to be preached. It also indicates procedural and disciplinary matters for the chaplains, singers and other officers of the chapel as well as information about the care and schooling of the cantorçicos (choirboys). The only reference to musical performance is somewhat cryptically given, and concerns the singing of the Alleluia during mass. (It is possible that it was made at the behest of the maestro de capilla in order to clarify certain misunderstandings among choir members at the time this clause was formulated. $)^{30}$

29 The document is included in Barbieri papers 2, doc. 136.

${ }^{30}$ For more details, and an interpretation of this passage, see below, pp. 140-41, where it is also posited that this clause predated Charles V's arrival in Spain and originated in practices in the chapel of the Catholic Monarchs. 
A survey of about the first half of Charles V's Estatutos reveals that they were heavily modelled on the French Burgundian statutes issued by himself in Brussels in 1516, which in turn were derived from a standard set of issues forming the basis of ordinances issued by the Burgundian dukes in the fifteenth century. In this regard, Charles V's 1516 Statutz et ordennances is pivotal. This fact provides a very important context for the apparent legislative structure of the royal chapel, its enormous debt to tradition, and the origin of a few statements or terms which, in other respects, perhaps fall outside normal terms of reference in Iberian liturgical history and can best be understood in terms of their Franco-Burgundian heritage. Analysis of the Spanish Estatutos shows that the first nine items were directly modelled on a selection of ten of the twelve items forming the 1516 Statutz, and that these can be traced back at least to the ordinances issued during the time of Charles the Bold: the 1469 Ordennances de L'Hostel, in the section 'Ordennances touchant la chapelle', and the Statutz et ordennances reisssued by Philip the Fair in $1500 .{ }^{31}$ For instance, the former (1469) stipulation that mass should be celebrated (as was traditional) according to the Use of Paris - 'le tout en observant et gardant l'usage de l'eglise de Paris', though omitted in the 1516 Statutz, evidently inspired the direction in Charles V's Spanish statutes that all offices in the royal chapel should, from henceforth, be celebrated according to the Use of Rome and therefore be distinguished from those of Parisian Usage: 'Mandamos que de aqui adelante el Officio Divino se celebre en Nuestra Capilla conforme al Vzo, y Costumbre de la Iglesia Romana' (clause 2), a mandate which was preserved in the copy reissued during Philip II's time.$^{32}$ Further, in referring to the Temporale, and the changes

31 Observations about the connections between the various court chapel statutes have also been made by Robledo in 'La música en la corte de Felipe II', p. 148. For transcriptions of these documents, see D. Fallows, 'Specific Information on the Ensembles for Composed Polyphony, 1400-1474', in S. Boorman (ed.), Studies in the Performance of Late Mediaeval Music (Cambridge, 1983), pp. 109-59, at pp. 146-59, G. van Doorslaer, 'La Chapelle musicale de Philippe le Beau', Revue belge d'archéologie et d'histoire d'art, 4 (1934), pp. 21-57, at pp. 45-6, Vander Straeten, La Musique aux Pays-Bas, vii, pp. 278-81, and Schmidt-Görg, Nicolas Gombert, pp. 340-2.

32 Whether or not this took effect immediately in Charles V's reign is at present difficult to gauge. In the Castilian court chapel of Ferdinand and Isabella both the Roman and the Toledan Rites had been followed. See T. W. Knighton, 'Music and Musicians at the Court of Fernando of Aragon, 1474-1516' (Ph.D. diss., University of Cambridge, 1983), p. 129. It is therefore of some interest that a document issued by Philip II in 1584, the 
of mass times in the 'winter' and 'summer' seasons (clause 3), it is intriguing that in the Estatutos (but not in the Burgundian statutes consulted, however) the beginning of the first season is associated with the feast of St Remigius (1 October) when morning mass was to begin at 9 a.m., as opposed to 8 a.m. for the second season beginning at Easter. The custom of marking the feast of St Remigius with a change of mass time was one evidently derived from practices in northern Europe (as, for instance, at the French royal court), where this saint had an important association. ${ }^{33}$ Reference to this date in both versions of the Estatutos was made solely in connection with the saint's feast day, and not by calendar day, and the spelling of the saint's name in the original Estatutos of Charles V (Remis) was derived from the French Saint Rémy, or Remis; in the later version of these statutes, the name was hispanicised to 'San Remegio'. ${ }^{34}$ Table 1 comprises a summary of the statutes from the Burgundian court chapel and those issued by Charles V, first in Brussels and then in Spain. ${ }^{35}$ Here it can be seen how a combination of items from the ordinances of Charles the Bold resulted in the formation of Charles V's French Statutz, and how all these relate to the two sets of Spanish statutes, where the French term bureau for the governing body of the Burgundian House is retained (clause 9). ${ }^{36}$

The precise origins of the remainder of the Spanish Estatutos (clauses 10-24) have not been traced, though there is the possi-

Advertencias de como se ha de ganar y repartir las distribuciones, specifies that chant of Toledan Usage should be used in the royal chapel: 'El canto llano de la capilla sea conforme al toledano ... que así lo disponen las bulas de la Real Capilla' (Barbieri papers 2, doc. 161). See Robledo, 'La música en la corte de Felipe II', pp. 151-2.

33 St Remigius was Bishop of Reims in the early sixth century. There was a special chapel dedicated to this local saint in Notre-Dame; see C. Wright, Music and Ceremony at Notre Dame of Paris, 500-1550 (Cambridge, 1989), pp. 133-4.

34 During the course of the sixteenth century, the saint's name began to be dropped in Spanish documents in favour of just the date. By the late sixteenth century, some royal chapel documents merely refer to these two seasons as 'winter' ('invierno') and 'summer' ('verano'). This was only loosely related, therefore, with the Temporale. In the Advertencias dating from 1584, however, while specifying 1 October for a change of mass time, it is stated that the next season was to begin on the first day of Lent ('el primero día de cuaresma'). See Barbieri papers 2, doc. 161, item 3.

35 For sources and transcriptions of these and other royal chapel documents see Appendix 2.

${ }^{36}$ In the later, and slightly abbreviated, copy of the Estatutos, the word is translated as Bureo. See Barbieri papers 2, doc. 135[b]. 
Table 1 The origins and formation of Charles V's Estatutos (summary)

\section{Charles the Bold \\ Ordonnances touchant la chapelle $^{a}$}

(1469)

2. Chapel officers to be subject to the first chaplain

3. Sung daily mass celebrated according to the Use of Paris

\section{Sung daily Vespers} and Compline

5. Matins and Little Hours to be celebrated on major feast days listed

12-14: Robing and appearance of chapel officers
Statutz et ordonnances pour ladite chapelle (reissued in 1500 by Philip the Fair)

1. Sung daily Mass, Vespers and Compline, at the stipulated hour and place where [the duke] is;

\section{Charles the Bold}

robing and appearance of chapel officers

2. Officers to kneel on entering the chapel and pay homage to the Lord,
Charles V
Statutz et ordonnances sur le
faict de nostre grande chapelle (Brussels c. 1516)

1. Chapel officers to be subject to the first chaplain

2. Sung daily mass [omits Use of Paris]

\section{Sung daily Vespers} and Compline

4. Matins and Little Hours to be celebrated on major feast days listed

5. Officers of the chapel to celebrate the divine office wherever [the duke] is;

robing and appearance of chapel offices

6. Officers to kneel on entering the chapel and pay homage to the Lord,

\section{Charles V}

Estatutos de la capilla... al vzo de la Caza de

Borgoña (Spain, c. 1518)

1. Chapel officers to be subject to the major almoner [limosnero mayor]

2. Mass and other offices celebrated according to the Use of Rome

3. Sung daily mass: 9 a.m. from the feast of $S$. Remis to Easter; 8 a.m. from Easter to S. Remis.

Offices to be celebrated in nearby church when there is no chapel in the

[Emperor's] palace; sung daily Vespers and

Compline according to the Use of Rome

\section{Charles V \& Philip II}

Constituciones o estatutos de la Real Capilla ... al vzo de Borgoña (Spain, c. 1560)

1. Chapel officers to be subject to the major almoner [limosnero mayor]

2. Mass and other offices celebrated according to the Use of Rome

3. Sung daily mass: 9 a.m. from the feast of $S$. Remigio to Easter ('Pascha de flores'); 8 a.m. from Easter to $S$. Remigio. Vespers at 3

p.m.

Offices to be celebrated in nearby church when there is no chapel in the [king's] palace; 4. Sung daily Vespers and Compline according to the Use of Rome

4. Robing and appearance of chapel officers

5. Robing and appearance of chapel officers

5. Officers to kneel on entering the chapel and pray
6. Officers to kneel on entering the chapel and pay homage to the Lord 
19. Officers to maintain silence (etc.) during the offices

24. Officers to attend chapter meetings every Monday on disciplinary matters, led by the first chaplain or another official meetings]

27. No absences to be taken without permission of the first chaplain [25-6: further details of chapel patron

3. Officers to stand during listed items of

the mass and the offices 4. Officers to maintain

silence during the offices 5. Officers to undertake their assigned duties 6. Officers to attend chapter meetings at least once a week on disciplinary matters, and to obey the first chaplain

7. If the first chaplain fails to impose punishments, this task should be undertaken by the [duke's] confessor, M. de Salubrye

8. First chaplain to report presences and absences to the bureau on a daily basis

9. Chaplains and officers to follow the statutes and ordinances of Duke Charles of Burgundy [end of document] the Virgin Mary and the the Virgin Mary and the chapel patron

7. Officers to stand during listed items of the mass and the offices 8. Officers to maintain silence during the offices 9. Officers to undertake their assigned duties 10. Officers to attend chapter meeting at least once a week on disciplinary matters, and to obey the first chaplain

11. If the first chaplain fails to impose punishments, this task should be undertaken by the [duke's] confessor

12. First chaplain to report presences and absences to the bureau on a daily basis

9. Absences taken without the major almoner's permission to be reported to the bureau by the furrier

[end of document] the mass and the offices and the chapel patron
6. Officers to stand during listed items of 7. Officers to maintain silence during the offices

8. Major almoner to hold chapter meetings of officers of the [Flemish] chapel every Friday on disciplinary matters
7. Officers to stand during listed items of the mass and the offices 8. Officers to maintain silence during the offices

9. Major almoner to hold chapter meetings of officers of the Flemish chapel every Friday on disciplinary matters
10. Absences taken without the major almoner's permission to be reported to the bureau by the furrier
${ }^{a}$ Only the clauses which relate to the succeeding sets of statutes on this table are entered in this column.

${ }^{b}$ For details, see n. 65. This and the succeeding clause about behaviour in chapel are also covered under clause 7 in Enrique IV's Constituciones de la Real Capilla of $c$. 1436. See Barbieri papers 2, doc. 124, p. 23. 
bility that some of the clauses were inspired by constitutional texts inherited from the courts of the Catholic Monarchs, despite the fact that some of the issues raised are of a general nature and could therefore obtain in any number of European court chapels. It is only in this portion that isolated musical references are made and indications given as to the care and schooling of the choirboys - matters which were to be expanded in Philip II's Constituciones para el Real Colegio de Cantores de la Real Capilla of about the 1580s. ${ }^{37}$ That the whole of this document was recopied in $c$. 1560, shortly after Philip II's return to Spain, gives further indication of Philip II's apparent respect for tradition regarding liturgical observances, ceremonial practice and chapel regulations, and even dress as it was 'in former times'. (See Table 2.)

One other important constitutional document of the Spanish royal chapel which was apparently reinstated at the beginning of Philip II's reign is the Latin Leges et constitutiones originating sometime in the early sixteenth century, if not before. As the only version of this text recovered to date was recopied in the late sixteenth century, and thus well after its initial conception and subsequent revisions, scholars have expressed some disagreement as to its origin and function. ${ }^{38}$ While Vander Straeten contended that it was formulated during the time of Philip the Fair, and that subsequent additions were made up to 1568 in order to account for a number of royal anniversaries, Bouckaert has dated it to 1556, and Robledo has placed it firmly in the reign of Philip II while (similar to Bouckaert) acknowledging its origins in 'the Burgundian tradition' ('la tradición borgoñona'). ${ }^{39}$ In contrast to the Estatutos, which is more concerned with procedure and etiquette, this document is more informative about musico-liturgical matters, listing several occasions for the performance of items in

37 The document is included in Barbieri papers 2, doc. 157.

38 This text was first edited by Vander Straeten in La Musique aux Pays-Bas, vii, pp. 183-6, and has subsequently been discussed in Schmidt-Görg, Nicolas Gombert; H. Rudolf, 'The Life and Works of Cornelius Canis' (Ph.D. diss., University of Illinois, 1977); L. Robledo, 'La música en la corte de Felipe II', pp. 146-8; and Bouckaert, 'The Capilla Flamenca', pp. 39-40. The full title of the document preserved in the Palacio Real in Madrid (EMpa, Administrativa, leg. 1133) reads: Leges et constitutiones capellae Catholicae Maiestatis, à maioribus institutae, à Car. Quinto studiosè custoditae, hodierno die, mandato Regis Catholicae, singulis sanctissimè servandae.

39 Bouckaert, 'The Capilla Flamenca', p. 39, and Robledo, 'La música en la corte de Felipe II', p. 146. 
Table 2 Charles V's Estatutos (summary of clauses 10-24)

\begin{tabular}{l} 
Charles V: Estatutos \\
(cont.) \\
\hline 10. List of Sundays and selected feast \\
days throughout the year for sermons \\
11. Positioning of celebrant before \\
the altar at the beginning of Matins, \\
Vespers, Compline and Vigils, and of \\
those reciting the Gospel, the Epistle \\
and the Lessons of Matins
\end{tabular}

12. Obligation for singers to sing a duo or trio when ordered by the chapel master

13. From henceforth, the Alleluia to be sung (in polyphony) every day, as on major feast days, and the chapel master should order the singers to take turns in singing (the Alleluias)

14-16. From henceforth, the chapel master must accompany the choirboys to and from the chapel; other details of care and schooling of the choirboys

17. Details of annual allowance of robing of chapel officers and choirboys, and order that they should be dressed as in former times ${ }^{a}$

18. From henceforth, all admitted to the Flemish chapel to take an oath of allegiance in the presence of the major almoner ${ }^{b}$

19. No books of chant or of polyphony to be taken out of the chapel
Charles V and Philip II: Constituciones o Estatutos (cont.)

11. List of Sundays and selected feast days throughout the year for sermons

12. Positioning of celebrant before the altar at the beginning of Matins, Vespers, Compline and Vigils, and of those reciting the Gospel, the Epistle, and the Lessons of Matins

13. Obligation to sing a duo or trio 'in front of the book' [i.e. super librum] when ordered by the chapel master

14. From henceforth, the Alleluia to be sung (in polyphony) every day, as on major feast days, and that the master of the choirboys [= chapel master] should designate the voice parts to the singers, and that no one should refuse to sing the duo or trio, or whatever else was deemed suitable

15-17. The chapel master must accompany the choirboys to and from the chapel; other details of care and schooling of the choirboys

18. Details of annual allowance of robing of chapel officers and choirboys, and order that they should be dressed as in former times

19. That all admitted to the Flemish chapel to take an oath of allegiance in the presence of the major almoner

20. No books of chant or of polyphony to be taken out of the chapel, not even for the purposes of teaching or any other singing 


\begin{tabular}{l} 
Charles V: Estatutos \\
(cont.) \\
\hline 20. From henceforth, no one should \\
play [music] in mass or Vespers \\
without first advising the major \\
almoner or, in his absence, the chapel \\
master, and that the offices should be \\
according to the Use of Rome
\end{tabular}

21. Positioning of the chapel master behind the choirboys

22. The chapel master to be responsible for looking after the music books and for choosing music for the divine offices

\section{The above [i.e. the statutes] should be declared publicly to all chapel members (by the major almoner)}

24. The chapel steward (furrier) should be in the chapel before each service to ensure that the chapel officers perform their duty on entering [see item 5]

\section{Charles V and Philip II: \\ Constituciones o Estatutos (cont.)}
21. No one should order for the bells to be rung before mass or Vespers without first advising the major almoner or, in his absence, the chapel master, nor begin the services without his permission, and that the offices should be according to the Use of Rome

23. Positioning of the chapel master behind the choirboys

22. The chapel master to take care of the music in the offices, and all should obey him

\section{All contents [of this document] should be declared publicly to all chapel members (by the major almoner)}

25. The porter and the housing master (aposentador) should be in chapel every day before each service to ensure that all perform their duty regarding the above

${ }^{a}$ For details of the allowances made in 1559, and a description of the dress of the choirboys, see Vander Straeten, La Musique aux Pays-Bas, viii, pp. 25-7.

${ }^{b}$ This also constitutes the third clause in the Constituciones de la Real Capilla of $c$. 1436, 'Que los capellanes juren a su entrada en manos del capellan mayor o de su lugarteniente'. Barbieri papers 2, doc. 124.

fabordón, for example, as well as a few occasions for the singing of polyphonic motets. It also outlines procedures in offices for commemorations of the dead - a section undoubtedly updated in the early years of Philip II's reign as, in the lines of La Orden, it refers specifically to the exequies of the Emperor and members of the House of Austria and here there are clear indications of practices stemming from Parisian Usage (see below). ${ }^{40}$ Significantly, it also

40 See below, 'Royal anniversaries and commemorations'. 
provides information about performing traditions, in particular about the positions of members of the choir around the music stand, and it is in these clauses especially that perhaps the origins of the document may be most closely considered. Here, instead of referring to a four-part adult choir and choirboys, such as characterised the chapels of Charles V and Philip II, the document refers to arrangements of first a three-part adult choir with a group of choirboys (for the top line), and then a three-part adult choir on its own, with the voice parts designated as contratenors, tenors and basses. ${ }^{41}$ There is thus no mention of the tiples which formed a regular part of the Spanish royal chapel in the sixteenth century. The origin of this particular positioning of a choral group cannot at present be verified. David Fallows's discussion about performing ensembles in the fifteenth-century Burgundian court chapel and similar institutions, in which he concludes that the normal four-part distribution of voices in polyphonic performance in at least the 1469 chapel of Charles the Bold (according to the pay records) involved adult singers only, despite the probable use of boys in the chapel, unfortunately throws little light on the implications of these passages, therefore. ${ }^{42}$

\section{PHILIP II'S CHAPEL}

The complexity of the organisation of the Philip II's royal court and chapel, with its dual bureaucratic structure represented by the 'House of Burgundy' and the 'House of Castile', has recently formed the basis of a series of important studies by Luis Robledo. ${ }^{43}$ His findings are founded on the interpretation of a wide selection

41 'XXVII. In supplicationibus, pueri medium, tenores sinistrum, contratenores dextrum, gravi toni novissimum locum occupando', and 'XLII. Unusquisque suum locum occupet, nimirum contratenores lateris dextri, tenores sinistri, bassi vero (ut vocuntur) postremi'; Leges et constitutiones, clauses 37 and 42.

42 See Fallows, 'Specific Information', pp. 110-14, 117, 125 and 143-4, and H. M. Brown, 'Music and Ritual at Charles the Bold's Court: The Function of Liturgical Music by Busnoys and his Contemporaries', in P. Higgins (ed.), Antoine Busnoys: Method, Meaning and Context in Late Medieval Music (Oxford, 1999), pp. 53-70, at pp. 54-8. I would like to thank Bonnie Blackburn for drawing the latter reference to my attention.

43 Robledo's work on the history and formation of the Castilian royal court and chapel (particularly that of Philip II) is of extreme importance, enabling me to evaluate the significance of $L a$ Orden among other royal constitutional documents. References to his studies are cited throughout this article. 


\section{Bernadette Nelson}

of documentary material, including a number of statutes and other constitutional texts, and he is the first to clarify that, musically, Philip II's so-called Capilla flamenca and Capilla española were in fact sections of a unified institution directed by one maestro de capilla ${ }^{44}$ the maestro de capilla was traditionally a member of the House of Burgundy, and hence always Flemish. ${ }^{45}$ The singers, choirboys, organists and other musicians of the capilla flamenca and española are therefore listed separately in the documents, even though members from both institutions combined forces during the celebration of the liturgical offices. While the head of the chapel during Charles V's time was the first almoner (the equivalent of the first chaplain in the Burgundian court chapel), it was the capellan mayor who was instated as official head of the chapel on Philip's accession to the throne, this post having originally been inherited from the Casa de Castilla of Charles V. ${ }^{46}$ In practice, however, the limosnero mayor (there was usually more than one of these) enjoyed equal status with him, and substituted for him in his absence from court. ${ }^{47}$ Other members inherited from Charles V's capilla española included the first sacristan (sacristan mayor) and the receptor. These four high-ranking officers, with the chamberlains of the king's oratory (sumilleres del oratorio), head the list of the 'Officers of the chapel' (Officiales de la Capilla) in La Orden, seemingly the only royal chapel document from the time to list their various duties in that hierarchical order, though it is not clear from other documents whether these latter two maintained exactly the same roles after

44 This corrects the previously held notion that the two chapels existed independently, despite the fact that only one maestro de capilla is recorded in the documents. For further details and a clarification of the organisation of the royal institution, see Robledo, 'La música en la corte Madrileña', p. 790, and idem, 'Sobre la capilla real de Felipe II', Nassarre, 4 (1988), pp. 245-8. See also Robledo, 'La música en la corte de Felipe II', pp. $143-4$.

45 This situation persisted until 1637 when a Spaniard, Carlos Patiño, was appointed maestro de capilla.

46 See Robledo, 'La música en la corte de Felipe II', p. 143.

47 The absence of the capellan mayor was evidently quite common, particularly during the early years of Philip II's reign. For instance, neither of the two capellanes officially forming part of Philip's Spanish chapel in c. 1556-9 - Pedro de Castro, bishop of Cuenca, and Gaspar de Zúñiga y Avellaneda, archbishop of Santiago, who was appointed on 1 May 1558 - formed part of his train on the voyage to Flanders and England. Avellaneda was, however, present at court from 1561. See H. Anglés, La música en la Corte de Carlos $V$, i, p. 137, and Barbieri papers 2, doc. 156[a]. See also Appendix 5. 
Philip's accession to the throne. ${ }^{48}$ Other officers of the chapel included the chaplains, officially designated as 'chaplains of the bench' (capellanes de banco) and 'chaplains of the altar' (capellanes de altar) according to whether they were members of the Spanish or Flemish chapels respectively, the clerks of the oratory and of the chapel (mozos de oratorio and de capilla); and the chapel steward (furrier, or sometimes called the portero or aposentator). There was also the first almoner's personal clerk called the mozo de limosna.

The upheaval in the Imperial court around the time of Charles V's abdication from October 1555 must have been quite considerable. Judging from the available lists of chapel officers at this time, and comparing the names and numbers of those from his Flemish chapel who 'survived' the transition to Philip's own Capilla on his accession to the throne, and then to Spain (travelling after the beginning of August 1559), this period of adjustment only gradually achieved stabilisation: see Appendix $5 .{ }^{49}$ Further, a few officers from Charles's chapel accompanied the Emperor to Spain in 1556 to serve him in his chapel and monastery at Yuste; $;^{50}$ at least one of these returned to Flanders following the Emperor's death in order to take up service in Philip's chapel and follow him to Spain. ${ }^{51}$ Only a portion of the original group of seventeen Flemish singers and eight chaplains from Charles's chapel in 1556

48 The list of chapel officers and their duties forms the last section of the document originally compiled by Aguirre (La Orden, fols. $\left.71^{v}-76^{v}\right)$. For a summary of the duties and responsibilities of the various officers of the royal chapel as described in La Orden and the 1545 Estriquete y Relascion, see Appendix 1.

49 The information presented in this table has been collated from the documents transcribed in Anglés, La música en la Corte; Vander Straeten, La Musique aux Pay-Bas, viii (Brussels, 1888); M. A. Virgili Blanquet, 'La capilla musical de Felipe II en 1562', Nassarre, 4 (1988), pp. 271-80; and Robledo, 'La música en la corte Madrileña'. Unfortunately, there are a few discrepancies in the available documents, and the extent of, for example, a chapel member's period of leave is not always clear. However, the juxtaposition of the available information about membership in the Flemish and Spanish chapels during this period (the end of Charles V's sovereignty and the first six of Philip II's) does give some indication of the membership, and the extent of fluctuation during the final years of Nicolas Payen's tenure as chapel master, and the first three of Manchicourt's. According to Vander Straeten, Manchicourt was responsible for a certain degree of reform (see below, n. 52).

50 The choir at his Jeronymite monastery at Yuste was also formed by singers coming from various Jeronymite convents in Spain. For a list of members, see Vander Straeten, $L a$ Musique aux Pays-Bas, vii, pp. 361-3.

51 The chaplain George Nepotis is recorded as having left Flanders in 1556, with the Emperor, returning in 1559 to serve Philip; Vander Straeten, ibid., vii, p. 365, and viii, p. 45 . 
apparently followed Philip to Spain, while a few more were recruited between late 1558 and August 1559, thus making a total number of about fifteen officers and a dozen choirboys who joined Philip's chapel; among these was the organist Michel Boch, ${ }^{52}$ who was to remain in the royal chapel in Spain along with Antonio and Juan de Cabezón for many years.

This period of transition was probably complicated further by the numbers of chapel members from Philip's own chapel, including several musicians, who asked for leave of absence to return to Spain in 1556; many never returned to the Netherlands. ${ }^{53}$ These included a number of key singers and choirboys, ${ }^{54}$ instrumentalists, ${ }^{55}$ as well as the organist and keyboard player Antonio de Cabezón, who was given a year's leave in January $1556 .{ }^{56}$ His brother Juan de Cabezón and Cristóbal de León (organist and organ tuner), however, remained in Philip's service throughout this period in the company of the Flemish organist Michel Boch. There were always about twelve choirboys in Charles V's chapel, the number specified in $\operatorname{La} \operatorname{Orden} ;{ }^{57}$ by 1562 , the total number of twenty-two in Philip's chapel comprised seventeen Flemish and five Spanish choirboys. Nicolas Payen, who had served in the Imperial chapel since his term as choirboy from 1526, was Charles V's

52 Michel Boch played a large role in recruiting new officers and choristers in 1561/2, involving considerable time and expense. We also learn of fifteen 'chantres' from the Flemish chapel retiring at this time and being replaced by fourteen new ones. See Vander Straeten, La Musique aux Pays-Bas, viii, pp. 39-43, and Appendix 5.

53 Some musicians went to serve in the chapel of Don Carlos, Philip's son. See Anglés, $L a$ música en la Corte, p. 139. A number of Philip's court musicians, including his maestro de capilla Pedro de Pastrana, remained in Spain during this period and went to serve his sister María, who was married to Maximilian of Austria. Anglés, ibid., p. 106.

54 A few choirboys (whose voices had presumably broken at that stage), such as Bernaldo Monje, Agustín de Cabezón and Francisco de Torres, were given leave of absence for longer periods in order to study (with scholarships from the King) at the University of Alcalá de Henares. See Anglés, La música en la Corte, pp. 137-8. The choirboys were normally sent off for a three-year training with the aim of returning as singers when they had regained their voices. See Estriquete y Relascion, ed. Schmidt-Görg, in Nicolas Gombert, p. 339.

55 For the names of the group of instrumentalists see Anglés, La música en la Corte, pp. $139-40$.

56 Following Queen Isabella's death in 1539, Cabezón spent much of his time in the household of Prince Philip, as well as that of his sisters, but after 1548 he was officially employed in Philip's chapel. After returning to the Netherlands from leave, he accompanied Philip to England on the occasion of the prince's marriage to Mary Tudor in July 1557.

57 'Los niños suelen ser ordinariamente doze'; La Orden, fol. $76^{\mathrm{v}}$. 
chapel master at the time of the Emperor's abdication, and continued as Philip's maestro de capilla until his death in February 1559. He was succeeded by Pierre de Manchicourt the following April, who remained in this post until his own death in 1564, thus directing the chapel choir for about the first five years after Philip's return to Spain. By July 1562 there were about thirty-five singers in the royal chapel, of which twenty were Flemish. Of the fifteen Spanish singers, all but three were listed as members of Philip's Spanish chapel in 1556, thus showing some degree of stabilisation there, though about half a dozen of these had returned to Spain during the intervening period. The documents show that the voice parts of the Spanish singers were divided more or less evenly into four groups comprising tiples, contraaltos, tenores and contrabaxos, though only three tiples are ever listed at one time. While the changeover of sovereignty instigated certain readjustments in the two chapels between $c .1556$ and $c .1560$, and the two musical forces only officially amalgamated at this time, it is probably true that members of both Charles's and Philip's musical chapels had already performed together on a great number of other occasions following Philip's arrival in northern Europe in the spring of 1549.58

\section{LITURGICAL OFFIGES IN THE ROYAL CHAPEL}

Gentral to the run of liturgical offices in the royal chapel was the daily celebration of High Mass, or the 'Missa cantata', which normally took place at 8 a.m. in the 'summer' season, or 9 a.m. in the 'winter' season. ${ }^{59}$ In addition, the most commonly celebrated liturgical offices were Vespers and Compline, and vigils comprising first

58 Philip and his court left Spain in November 1548, travelling first to Italy, then through Germany, arriving in the Low Countries in late March 1549. He met his father for the first time in six years, in Brussels, on 1 April. See Kamen, Philip of Spain, pp. 35-40. It was at about this time that Charles V's Spanish chaplain Miguel Pérez de Aguirre originally compiled his account of customs and rituals in the Emperor's chapel, and therefore a period when Philip and his court may well have been initiated into ceremonies and procedures peculiar to the Imperial chapel.

59 These times are specified both in Charles V's Estatutos (clause 3) and in La Orden (fol. 63). The two seasons of the Temporale began at Easter and 1 October (the feast of St Remigius) respectively (see above). According to La Orden mass could start an hour later on Sundays and major feasts when the King was not present. 


\section{Bernadette Nelson}

Vespers, Matins and Lauds on major and minor feasts, as well as on anniversaries and commemorations. La Orden specifies only the following days for Vespers: every Saturday and Sunday, feasts of the Virgin Mary, the Apostles and the Four Doctors of the Church, and Holy Days of Obligation ('fiestas de guardar'); Compline was always to be celebrated when Vespers was over on these days even when it was celebrated pontifically ${ }^{60}$ It also states that on Sundays during the Lenten period, Vespers and Compline were to take place in the afternoon. ${ }^{61}$ The only other time specified in La Orden is for Matins on Christmas night, which was to begin at 10 p.m. ${ }^{62}$ In the revised set of Estatutos issued for Philip II's chapel, a time for Vespers is given as 3 p.m. ${ }^{63}$ In all events, and including when the chapel was obliged to use a neighbouring church for the offices during the king's travels, the same times were to be observed throughout the year and the degree of solemnity of the liturgy was to be commensurate with the rank of feast and celebrated in accordance with the Roman Use:

And when His Majesty is accommodated in some part where there is no convenient place to celebrate and sing the divine office in [the] palace, it is ordered that [it] be celebrated at the normal hour, and this in the nearest church or chapel to the palace ... Also, that on all solemn feasts, major and minor, that are observed in the village where His Majesty is [residing], Vespers and Compline are sung, and it is [to be] understood that the major solemn feasts be said differently from the minor [ones], as obtains in every feast in the ceremonies and all the rest according to the Roman Use. ${ }^{64}$

That the major musical items in the offices were sung in polyphony (particularly on major feast days) is thus generally understood merely by implication in the statutes, though there is ample evidence of music once forming the core of repertories performed by the royal chapel choir in the set of inventories compiled at the end of the sixteenth century (see below). In another clause in Charles V's Estatutos, and in line with all statutory texts dating

60 La Orden, fol. 64. In this section of La Orden, Aguirre also provides a few details concerning the positioning of the semanero officiating and of his robing.

61 Ibid., fol. 65.

62 Ibid., fol. 67.

63 'Las vísperas se digan a las tres horas de la tarde'. See Barbieri papers 2, doc. 136, clause 3.

64 These details from clauses 3 and 4 in the revised set of Estatutos slightly expand on the information provided in clause 3 of the earlier set. 
from the time of the Burgundian dukes and the fifteenth-century Castilian court, for instance, a selected number of items of the mass and of Vespers and Compline is listed during which the chaplains and singers were obliged 'to stand'; no other instructions are given. ${ }^{65}$ The instruction regarding a polyphonic Alleluia at mass in the Estatutos is an exception. ${ }^{66}$ However, more information on musico-liturgical practice is provided both in La Orden and in the Leges et constitutiones, with the latter indicating the extent to which fabordón was practised in the psalms, hymns and responses, and how a motet was to be sung during the procession at Corpus Christi. La Orden gives important insight into the performance in polyphony at Vespers and Compline: the singers were to begin the first verse of the first Vespers psalm - presumably as one group in an alternatim performing scheme, and on major feast days to sing either a Marian antiphon after Compline (on Saturdays) or a motet (on other days). It also specifically states that the Marian antiphon sung on Saturdays should be the Salve regina, but that from Easter to the feast of the Ascension the Regina caeli was to be sung with the organ responding. ${ }^{67}$

In addition, La Orden is particularly notable for providing some insight into ways in which musical performance was integrated with liturgical ceremony at mass and how this was evidently very carefully staged and choreographed. This is witnessed especially with the description of the sprinkling of hyssop during the performance of the antiphon Asperges me and the procession with the monstrance on Corpus Christi accompanied by verses of the hymn Pange lingua (see below). Despite the fact that these are among the few specific references to musical performance, the ways in which these rituals are described here is clearly indicative of the care taken over timing and procedure in other parts of the mass, all of which would presumably have been matched by appropriate musical elaboration as occasion demanded.

65 These invariably comprise the Introit, the Kyrie and Gloria, the Gospel, Credo, Sanctus, Pater Noster and the Agnus Dei of the mass, and the opening items and canticles (Magnificat and Nunc dimittis) of Vespers and Compline. See Estatutos, clause 7, and related passages in the statutes summarised in Table 1. A similar directive is divided between clauses 6,10 and 38 in the Leges et constitutiones.

66 See above, p. 115, and below, pp. 140-41.

67 See La Orden, fols. $64^{\mathrm{v}}-65$. 


\section{High Mass at the royal chapel}

Judging from La Orden, and other constitutional documents and accounts in chronicles dating from the time of both Charles V and Philip II, preparations for High Mass, particularly on Sundays, major feast days and pontifical occasions, were evidently quite considerable, with no expense spared. The tone of important occasions such as the celebration of the feasts of the Purification, Easter, Corpus Christi and Christmas, and royal anniversaries and commemorations such as the Emperor's birthday and meetings of the Order of the Golden Fleece, was invariably set by elaborate and colourful processions both on the vigils and on the day itself. These processions usually involved the king, his immediate court and other officials, clerics, and a band of musicians (sometimes singers), the size and extent varying as occasion demanded, with everyone processing in prescribed order (see below). The chronicles also provide vivid descriptions of the colour of the dress and the accoutrements of those involved.

Preparation of the chapel or church (depending on the lieu of the court at the time) itself was an extremely important part of the proceedings, and here also everyone was assigned a particular seating place according to rank. On pontifical and other important occasions, the walls may have been hung with special tapestries, the King's oratory draped with curtains appropriate to the occasion, and the benches and seats furnished with special fabrics and cushions. Henrique Cock, for instance, describes how for the pontifical mass on the occasion of the presentation of the Order of the Golden Fleece to three noblemen during Philip II's sojourn in Zaragoza in 1585, the King's oratory inside the iglesia mayor (presumably the cathedral) was draped with gold curtains. ${ }^{68}$ Similarly, in the royal chapel document El Etiqueta dating from 1545, for pontifical masses the wall facing the King's oratory was hung with a piece of tapestry of the same height, on top of which was fixed a length of scarlet velvet with gold trimmings; other details are specified for the decoration and furnishing in the vicinity. ${ }^{69}$ Much of

68 'En la iglesia mayor estaba adreçado el oratorio del Rey con cortinas de oro . . . For a description of this event, see H. Cock, Relación del viaje hecho por Felipe II en 1585, a Zaragoza, Barcelona y Valencia, ed. A. Morel Fatio and A. Rodríguez Villa (Madrid, 1876), p. 80.

69 See Vander Straeten, La Musique aux Pays-Bas, vii, pp. 401-2, and Barbieri papers 2, doc. $135[\mathrm{c}]$. 
this preparation would have been the responsibility of the mozos del oratorio, while the mozos de capilla would have ensured that the correct silver and other ornaments were displayed and ready for liturgical use. Likewise, the furrier and the 'candle boy' (mozo de la zereria) would have prepared the appropriate numbers of torches and candles according to the different occasions.

Preparation for the liturgical ceremony itself inevitably involved the interaction of several of the leading officers in the royal chapel, in particular the capellan mayor (when he was present at court), the limosnero mayor, the sacristan mayor, the receptor and the maestro de capilla. The degree of preparation depended on the category of office, and whether it was a pontifical occasion, a Sunday or a major feast, or an ordinary weekday. The limosnero mayor, for instance, regularly conferred with the maestro de capilla to ensure that the musical elaboration suited the particular occasion (especially when it was to be pontifical), while the receptor was frequently responsible for orchestrating the duties of various of the chaplains. Every chapel officer had his prescribed place, and the smooth running of this daily celebration was very much dependent on each taking responsibilty of his allocated duty - from the correct staging and rituals of the celebrants and the precise timing of the entry of the page-boys (pajes) with their torches, to the tuning of the organ. Of the ministers normally designated to perform the ritual of mass, the appointed deacon and subdeacon only performed their duties on Sundays and on special feast days, including days during Advent and Lent when a sermon was to be preached, while the bishop (possibly even the capellan mayor) would celebrate on pontifical occasions. Otherwise, the chaplains took it in turns to substitute for these officers on a rota basis for weekday masses along the lines established in the court chapels of the Burgundian dukes and the Catholic Monarchs: the chaplain appointed as celebrant on one week, and therefore called the 'semanero', would on the following week perform the role of deacon, and on the third that of the subdeacon. ${ }^{70}$ In all events, the Epistle was to be sung by the subdeacon (or acting subdeacon), and the Gospel by the deacon (or acting deacon), and none was allowed to excuse himself from

70 See La Orden, fol. $61^{\text {r-v }}$. In the Burgundian court chapel the celebrant of the week was called the sepmainier. See Fallows, 'Specific Information', p. 148 (item 7); see also Knighton, 'Ritual and Organization', p. 302. 
his week of duties. ${ }^{71}$ In the absence of the capellan mayor, or his deputy, this rota was organised by the receptor, and it is thus that Aguirre provides an almost exact choreography of movements surrounding the reciting of the Epistle and the Gospel, and how the missal (placed on its cushion) was passed from one lectern to the other by a mozo de capilla. ${ }^{72}$

Other ritualistic duties such as the administration of the hyssop, the giving of the missal to the king to kiss after the reading of the Gospel, the offering of the pax, and the holding of the salver or communion plate were all assigned to particular officers (especially the limosnero mayor), with the sacristan mayor and the receptor described as accompanying the groups of officers as they administered these rituals. La Orden also provides a precise record of the number of torches to be held by the page-boys at various points of the mass, which ranged from between two and six according to festal category and function - whether held during the reciting of the Gospel or at the consecration - and how these were only handed to the page-boys at the moment they were required. At the Gospel, torches were only held on important days: these varied between four on major feasts on the liturgical calendar, feasts of the Apostles and the Virgin Mary, and two on Sundays and other feast days when the deacon and subdeacon were officiating. After the Gospel, the page-boys (who normally stood on either side of the lectern) with their torches would then accompany those administering the Gospel blessing. Torches were always held by the pageboys at the consecration: six on major feasts, and four on all other occasions, including masses for the dead. Aguirre also describes how the page-boys entered with their torches at the beginning of the Sanctus. ${ }^{73}$

Aguirre's intimate acquaintance with the timing of the movements of the chapel officers in such rituals, especially where music was involved, informs his detailed description of the administra-

71 'Los capellanes han de tener cuenta con no faltar en sus semanas en los Officios que les toca'; La Orden, fol. $74^{\mathrm{v}}$.

72 Ibid., fol. $61^{\mathrm{r}-\mathrm{v}}$.

73 Information about the use of torches at High Mass ('Missas cantatas') is found in various parts of La Orden: principally fols. 61 ${ }^{\mathrm{v}}-62,66$ and $71^{\mathrm{v}}$ (La orden de servir las hachas en la Capilla). 
tion of hyssop accompanied by the singing of the Asperges $m e .^{74}$ It shows how the performance structure of the antiphon, the sequence of verses followed by the doxology, provided cues to the ministers for their movements and subsequent resumption of the liturgy of the Word. The antiphon is 'begun' (presumably intoned) by the priest at the foot of the altar steps, who then gives the hyssop to the deacon, and both go to serve water to the King. ${ }^{75}$ When the priest returns to his position at the foot of the altar, the $s a$ cristan mayor takes the hyssop and goes with a mozo de capilla (who carries the water) to administer to the apostolic delegate (if one is present), then the prelates, the chaplains and the singers, and afterwards the ambassadors and grandees and everyone else. As the singers finish singing the verses of the Asperges antiphon, the priest ascends to the altar alone to begin the prayers. When the 'ministers' (the deacon and the sacristan mayor) have completed their task, they also ascend to the altar, and the three of them stand at the middle of the altar until the singers begin the 'Gloria patri'. At that point, the priest dons his chasuble, which lies at one corner of the altar (on the Gospel side), and begins the Confession. Aguirre adds that on pontifical occasions the Asperges and the prayers are recited by the deacon.

\section{The Offertory}

A focal point of the mass proceedings was the Offertory and the accompanying procession which, particularly on major festal occasions and funeral services, was characterised by an elaborate array of lighted candles and torches involving large numbers of chapel officers, knights and court dignitaries. Sometimes the candles were embedded with a gold coin (un escudo) bearing the royal coat of arms or perhaps emblazoned with insignia and other heraldic devices appropriate to those attending the ceremony. ${ }^{76}$ There was

74 La Orden, fols. 62-3.

75 Aguirre adds that if there is no priest, the deacon performs this task (alone) and then returns to his place at the foot of the altar.

76 In La Orden references are made to the offering of candles embedded with un escudo during masses for the dead: in particular, mass on the feast of All Souls and the Requiem on the day after St Andrew's day (on the occasion of meetings of the Order of the Golden Fleece). An escudo was a term used both for arms and a gold coin bearing the royal coat of arms. It is possible also that the custom of emblazoning a candle with insignia such as is referred to in various chronicles and, indeed, in the fifteenth-century statutes of 
evidently much ritual and etiquette to be observed on these occasions, many of the customs no doubt emanating from those enjoyed in the Burgundian court chapel. La Orden is about the only royal chapel document to place some emphasis on this part of the mass, no doubt because of Aguirre's close involvement with the preparations of many of the gifts, several of which had specific monetary value. In addition to the list of occasions when there were special Offertory processions (Offrendas), ${ }^{77}$ other references to gifts are found scattered throughout the text, and some of these appear to reflect customs unique to the royal chapel. The numbers of people involved is not specifically stated, though this must have varied from occasion to occasion. Certainly on the feasts of St Michael and St Andrew, the days traditionally associated with the Orders of St Michael and the Golden Fleece respectively, the knights fully participated wearing their special robes of fifteenth-century Franco-Burgundian origin. ${ }^{78} \mathrm{We}$ are also given clear indications of the King's integral part on many of these occasions, particularly on the feast of the Epiphany, the anniversary of Charles V's birthday and coronation on the feast of St Matthias (24 February), the anniversaries of the deaths of Queen Isabella (1 May) and Charles V (21 September), and Philip II's own birthday on 21 May. Details provided in La Orden of the gifts themselves give us fascinating insight into traditions and enactments which have otherwise escaped historical accounts, though sometimes contemporary chronicles provide corroborative evidence.

the Order of the Golden Fleece in connection with the Requiem mass on the day after St Andrew's Day was followed on these occasions: 'a l'offerture de la quelle Messe le Souverain \& chacun des dits Chevaliers presents \& procureurs des absens offriront chacun ung chierge de cire armoyé des armes d'icelluy pour qui offert sera' (G. G. Leibnitz, Mantissa: Codicis duris Genitium Diplomatici [part ii] (Hanover, 1700), p. 25). See also below, n. 87.

77 La Orden, fols. $68^{\mathrm{v}}-69$.

78 The dress of the knights of these Orders on their respective feast days were different: that of St Michael consisted of long white robes and ermine fur capes, and that of the Golden Fleece of scarlet robes. A copy of the statutes of the Order of St Michael is preserved in the Bodleian Library, Oxford, MS Ashmole 775 (the dress is described on fols. $18^{v}-22$ ). For a description of the dress of the knights of the Order of the Golden Fleece, see W. Prizer, 'Music and Ceremonial in the Low Countries: Philip the Fair and the Order of the Golden Fleece', Early Music History, 5 (1985), pp. 113-53, at p. 119, where he refers to an original source for the statutes of this order. See also Leibnitz, Mantissa [part ii], 'III. Ordenances \& statuts de l'Ordre de la Thoison d'Or', p. 25. 
Many of these offerings apparently involved a gold coin, or coins, from the tradition of offering a single gold coin (ducado) as well as the candle embedded with a gold coin during masses for the dead, such as made by the King on the anniversaries of his parents, ${ }^{79}$ to the offering of a bag containing a set number of gold coins both on the Emperor's birthday (and coronation) and that of Philip II. Also, one may surmise that, in keeping with traditions of the Burgundian court, the offerings made by the knights of the Orders of St Michael and of the Golden Fleece on their respective feast days comprised gold coins and lighted candles. ${ }^{80}$ Further, on the feast of the Epiphany, and in imitation of the three Magi, the King made offerings of gold, incense and myrrh, which were afterwards given to poorly endowed churches and monasteries. ${ }^{81}$

It is interesting that for the offering made by 'His Majesty' on the feast of St Matthias, the Emperor's birthday, Aguirre makes no reference to the anniversary of the coronation as such, which could suggest that parts of La Orden were sketched out some twenty years before he compiled his own version. The juxtaposition of this reference to the Emperor's birthday with one to his son Philip's as King is therefore intriguing in the light of the possible chronological layers of this document: 'Day of St Matthias, on his birthday, His Majesty offers as many coins as years he has attained, and [one] more for the year in which he has entered; the King Our Lord does the same on the twenty-first of May. ${ }^{82}$ It is possible,

79 For more details, see below, 'Royal anniversaries and Offices for the dead'.

${ }^{80}$ It is clearly stated in the statutes both of the Order of St Michael and of the Golden Fleece that all knights (whether present or absent) should make an offering of a gold coin; see GB-Ob MS Ashmole 775, fol. $20^{v}$ and Leibnitz, Mantissa, [part ii], p. 25. It is, however, curious that while Olivier de la Marche's eyewitness account of ceremonies at the Burgundian court in the mid-fifteenth century includes a detailed description of the ritual of the candle ceremony which took place at the Offertory at mass at chapter meetings of the Order of the Golden Fleece, no reference is made to the offering of gold coins. See Olivier de la Marche: Mémoires [1474], ed. H. Beaune and J. D'Arbaumont, ii (Paris, 1884), pp. 90-2, and iv (Paris, 1888), pp. 179-80.

81 This ritual is described both in La Orden and in Charles V's 1545 El Etiqueta, but with a few discrepancies in detail between them. In the 1545 document, it is written that on each day of the Holy Kings, the King offers three cups made of gold (with the total value of about 100 ducados). In the first he offers a gold coin, in the second, incense, and in the third, wax (cera). In La Orden, as an offering on the day of Epiphany (no other occasions are mentioned), the three cups (valued at thirty ducados each) are again filled with a gold coin, incense and myrrh (mira). It is only in the 1545 document that we are told that these offerings are then appropriately distributed. See Vander Straeten, $L a$ Musique aux Pays-Bas, vii, pp. 402-3 and Barbieri papers 2, doc. 135[c].

${ }^{82} \mathrm{La}$ Orden, fol. $68^{\mathrm{v}}$. (See also above, n. 1.) 
therefore, that this ritual originated in the custom of Charles $\mathrm{V}$ making an annual offering of coins, the number being commensurate with his age. The date of his coronation in Bologna in 1530 was specifically chosen to coincide with his thirtieth birthday, and it is therefore fascinating to find in an eyewitness account of the coronation firm evidence that, at the Offertory during mass, the Emperor actually carried a bag containing thirty coins to the altar. ${ }^{83}$ That this commemoration of the Emperor's coronation was kept very much alive during Philip II's reign is witnessed both by accounts of traditions at El Escorial ${ }^{84}$ and in Henrique Cock's Relación of 1585, though Cock's vivid description of the colour and sounds of the processions involved does not include details of the mass celebration itself. ${ }^{85}$ Other days singled out in La Orden for 'offerings' include Christmas Day, the feast of the Purification (2 February), Easter, the feast of the Ascension, Corpus Christi and the feast of the Assumption (15 August), which is referred to merely by the popular Spanish festal designation Nuestra Señora de Agosto.

\section{Processions}

Lighted candles and torches also characterised the types of processions preceding and concluding mass, both in the immediate vicinity of the church or chapel and also in the streets, depending on the location of the royal court. ${ }^{86}$ As during the Offertory processions, these candles would often have been embedded with sil-

83 This is in Ugo Boncompagni's letter describing the coronation dated 18 March 1530 which reads: 'e anco quando il prefato Cardinale volse fare l'offertorio S.M. andò all'altare, ed offerse una bolsa con trenta doppioni da dieci ducati l'uno; e poi tornò alla sua sedia ... . See Lettera inedita del bolognese Ugo Boncompagni, poscia con nome immortale Gregorio XIII sommo Pontifice Romano, nella quale si descrive La Incoronazione di Carlo V Imperatore, seguita il 24 Febbraio 1530 in Bologna (Bologna, 1841), p. 8. A full description of both coronation days in February 1530 (the date of the Emperor's coronation on 24 February was in fact the second of the two) is given in P. de Sandoval, Historia de la vida $y$ hechos del Emperador Carlos V, ii, ed. C. Seco Serrano (Biblioteca de Autores Españoles; Madrid, 1956), pp. 367-73. The Emperor offered a bag of coins at mass on both these days. I should like to thank Bonnie Blackburn and Leofranc Holford-Strevens for providing me with a lead for the interpretation of this clause in La Orden.

84 At El Escorial, special commemoration services for Charles V took place on 24 February, and a Requiem mass was sung in his honour on the following day. See Noone, Music and Musicians, p. 41 (Table 2.1).

85 Cock, Relación, pp. 32-5.

${ }^{86}$ Numerous references to such processions are in the historical accounts of Sandoval and Cock. See, for example, the description in Cock's Relación (p. 250) of a procession for mass during Philip II's visit to Valencia in January 1586. 
ver plates embossed with appropriate insignia or embedded with a gold coin bearing the royal coat of arms. ${ }^{87}$ In a short section in La Orden headed Processiones, which immediately follows a description of ceremonies and music on Corpus Christi and its Octave, information is provided about the role of the King, his courtiers, and members of the clergy and other chapel officers. For the three feasts listed under this heading - Palm Sunday, Corpus Christi and the feast of the Purification - the court and clergy were to process in the following order: immediately behind the prelate officiating that day was to follow the King, while the ambassadors, princes, and grandees were to proceed in front of the prelate along with the bishops, the chaplains and the singers. This group was to be followed by the knights and all the rest 'in sequence', with the sacristan mayor and the receptor being responsible for seeing that the correct order was observed. In processions involving the Holy Sacrament (Corpus Christi), the King, the princes and other dignitaries held white candles. ${ }^{88} \mathrm{~A}$ full description of the procession following the blessing of the candles at High Mass on the feast of the Purification when the King went to a monastery, as was customary on this feast, is provided in the addendum to La Orden. The processing order tallies to a great extent with the general order just described, but on this occasion, besides the King, his chapel officers and courtiers, a large number of other court officials and church dignitaries are listed, including the majordomos, bishops and the delegate; further, the whole procession is led by two acolytes, a friar with a cross, and the entire community of friars. A detail is provided that the King was only presented with his candle once all his chaplains had joined the procession. Once the procession was over, the prelate (with his assistants and ministers) went to the high altar (Altar Mayor) and gave his blessing, and the singers provided the response. ${ }^{89}$

87 This was of course a characteristic feature of processions in many other European courts and religious communities, and was a particular feature of funeral services. An eyewitness account of the exequies for Charles $\mathrm{V}$ in Brussels, for instance, refers to citizens carrying white candles bearing the Emperor's coat of arms: 'docientos pobres con lobas y capirotes con hachas de cera blanca con las armas del Emperador ... $\therefore$ See L. Cabrera de Córdoba, Filipe Segundo, Rey de España (Madrid, 1876), p. 246.

${ }^{88}$ La Orden, fol. 68. See also below.

${ }^{89}$ This is presumably the verse and response, 'Dominus vobiscum: et cum spiritu tuo'. See La Orden, fols. $77^{\vee}-78$. 


\section{Music at mass}

There is no doubt that music - vocal polyphony especially - formed an extremely important and integral part of the proceedings, much of which was of course designed to accompany and correspond with specific liturgical ceremonies and rituals. The richness of the polyphonic repertories performed in the Spanish royal chapel can be measured by the series of inventories made of the musical collection at the end of the sixteenth century. ${ }^{90}$ Here are numerous choirbooks and part-books containing polyphonic mass settings, motets, Magnificats, hymns and psalms by a wide range of primarily Franco-Flemish composers, some of whom, such as Pierre de La Rue, Agricola, Gombert, Cornelius Canis and Crecquillon, had direct associations with the royal chapel from the time of Philip the Fair onwards. ${ }^{91}$ In addition, much of this repertory would have dated from the periods when Payen and Manchicourt were chapel masters. In 1602 Géry de Ghersem, lieutenant of the royal chapel, somewhat enthusiatically decided to empty the chapel library's collection of choirbooks, many of which he considered too old to be of any use or whose repertories were 'outmoded', which gives some indication of changing fashions in the royal chapel at that time. ${ }^{92}$

It is difficult in retrospect to judge exactly which of the items listed here would have been used regularly in the early years of Philip II's reign, but it is probable that this repertory would have

90 The inventories were compiled in 1597 as part of a larger project entitled Cargo del Officio de Guardajoyas de S.M. For further information and transcriptions of the inventories, see A. Andrés, 'Libros de canto de la Capilla de Felipe II', Música Sacro-Hispana, 10 (1917), pp. 92-5, 109-11, 123-6, 154-7 and 189-90; Vander Straeten, La Musique aux Pays-Bas, viii, pp. 352-83; and Barbieri papers 2, doc. 178.

91 La Rue entered the chapel of Philip the Fair in 1493; after Philip's death (in Spain) in 1506 , he remained there in the chapel of Juana the Mad, Philip's widow, only returning to the Netherlands in $c .1508$ (M. Staehelin, 'La Rue, Pierre de', The New Grove Dictionary of Music and Musicians, ed. S. Sadie (London, 1980), x, pp. 473-4). Agricola joined Philip the Fair's chapel in 1500, remaining there until his death in 1506 (E. R. Lerner, 'Agricola, Alexander', ibid., i, p. 162). Gombert became a singer in Charles V's chapel in 1526, and maître des enfants in 1529, and was succeeded in 1547 by Canis. He was a contemporary of Adrian Picart (= Thibault) who was maestro de capilla from 1526 to 1540 . In the 1540s the royal chapel included Canis, Crecquillon and Nicolas Payen. Canis left shortly after Charles V's abdication (see G. Nugent, 'Gombert, Nicolas', ibid., vii, p. 512; L. F. Bernstein, 'Canis, Cornelius', ibid., iii, p. 684; and H. M. Brown, 'Crecquillon, Thomas', ibid., v, p. 26).

92 Ghersem valued the entire collection for the paltry sum of just one thousand ducados. See Vander Straeten, La Musique aux Pays-Bas, viii, p. 353. 
included the masses of Josquin, Pierre de La Rue, Mouton, Gombert and Crecquillon, and other music acquired or copied during Charles V's reign. For example, there is almost conclusive evidence that the bulk of the collection of choirbooks now preserved in Montserrat was either passed over from Charles V's chapel following his abdication, or acquired shortly after Philip II's return to Spain in 1559 - these manuscripts having once formed part of the chapel collection of his aunt Mary of Hungary. ${ }^{93}$ This repertory includes a large collection of fifty-five complete mass settings by Lupus Hellinck, Benedictus Appenzeller, Manchicourt, Pierre de La Rue and others, and several motets, with one of the books being entirely devoted to twelve mass settings by Manchicourt (Montserrat 768). All of these choirbooks have been identified in Ghersem's inventory, and one of them, a book of four masses and eleven motets by Manchicourt himself (Montserrat 772), was copied by the maestro de capilla in $c .1560 .{ }^{94}$ It is no doubt significant that three of the four masses in this manuscript consist of a mass to the Holy Spirit, a Marian mass and a Requiem mass - the three masses traditionally celebrated at royal exequies and in the series of commemorations surrounding the feast of St Andrew which was normally associated with chapter meetings of the Order of the Golden Fleece. ${ }^{95}$ Unlike the majority of Manchicourt's masses, which are written for four voice parts, these three masses are scored for five or six voice parts, which probably gives some indication of the type and richness of polyphonic repertories performed in the royal chapel in the early 1560 s, at least on pontifical occasions, and Manchicourt's taste in music. The fact of Manchicourt's active involvement in music of the royal chapel at this time no doubt would have ensured a steady run of FrancoFlemish repertories such as would have accompanied his profes-

93 For details, see entries for MontsM 765, 766, 768, 772, 773 and 776 in Census-Catalogue of Manuscript Sources of Polyphonic Music, 1400-1550 (Renaissance Manuscript Studies, 1; Neuhausen-Stuttgart, 1982), iii. This collection of manuscripts also includes a book of twenty-five Magnificats by Benedictus Appenzeller, Clemens non Papa, La Rue and others (MontsM 769).

94 The volume is inscribed 'Liber quatuor missarum musicalium nec non aliquot carminum ecclesiaticorum; A Pedro de Manchicourt regie cappelle magistro conscriptus et compositus'.

95 See below. The three masses by Manchicourt are Missa Veni Sancte Spiritus, Missa de domina virgine Maria, and Missa de requiem. The fourth mass is his Missa Reges terre. See also below, n. 97. 
sional career in northern French cathedrals ${ }^{96}$ right up to his employment as royal maestro de capilla, starting in Brussels in April $1559 .{ }^{97}$

The information provided by both the set of inventories and the Leges et constitutiones would suggest that mass propers and responses were frequently sung in polyphony, particularly on Sundays, major feasts and pontifical days. These may have been settings in imitative counterpoint, improvised elaborations of the chants in contrapunto, or settings in fabordón for four or more voices, as witnessed especially by the series of entries in the Leges, for example at mass (and on the vigils) on the birthday of the king, the queen or the prince. ${ }^{98}$ Within the series of inventories of music books of the royal chapel are just two entries for books containing Introits (usually only the first item of a book is listed in the inventory), and a similar number containing mass responses - in particular a set of fabordones de la Missa included in a book of polyphonic masses and motets. ${ }^{99}$ There are also two books of fabordones by Manchicourt on these lists, which were almost certainly copied when he was in Spain; however, whether these included mass responses is not specified. ${ }^{100}$

A clause in Charles V's Estatutos suggests that the practice of singing the Alleluia in polyphony at every Mass, and not just on major feasts, was instigated during his reign, though this probably originated in slightly earlier practices in the Spanish royal

${ }^{96}$ Previous to his term at the royal chapel, Manchicourt had spent time at the cathedrals of Tours, Tournai and Arras. See J. D. Wicks, 'Manchicourt, Pierre de' in The New Grove Dictionary, x, p. 598.

${ }^{97}$ It is therefore probable that this background would have influenced his choice of music for at least three important events which occurred during his first months in this post while the court was still stationed in the Netherlands: the proxy wedding of Philip to Elizabeth de Valois in the cathedral of Notre-Dame in Paris on 15 June; the funeral rites (in Ghent) for Henry II of France on 24 July, and the chapter meeting of the Order of the Golden Fleece in Ghent beginning on 29 July. See Kamen, Philip of Spain, pp. $74-5$.

98 'In die nativitatis Regis, Reginae, Principis aut prolis regiae, in primis vesperis, completis, missa in omnibus versiculis et responsoriis fabordon canunto'; Leges et constitutiones, clause 16.

${ }^{99}$ See Vander Straeten, La Musique aux Pays-Bas, viii, p. 382. As these responses were usually improvised in performance, very few examples are to be found in surviving polyphonic manuscripts.

${ }^{100}$ The inventory entry indicates that the royal coat of arms is included on the first folio of these two books: 'Dos libros de un tamaño, enquadernados em papelon y cuero negro, y las armas reales en la primera hoja, de fabordón, de Manchicourt'; ibid. 
chapel. This stipulation is preceded by the dictum that the singers are obliged to sing a duo or a trio, if ordered by the maestro de capilla; the way these clauses are expanded in the version of the Estatutos issued during Philip II's time is strongly indicative that the Alleluia and its verse were sung in improvised polyphony super librum, which could be interpreted as contrapunto, a practice which was common at the time. ${ }^{101}$ A large number of Alleluia settings (but no other Proper items) survive in a series of manuscripts with strong associations with the 'court repertory' of the Catholic Monarchs. ${ }^{102}$ The majority of these Alleluias are anonymous, but at least two may be attributed to Escobar, who was associated with the royal court. ${ }^{103}$ All are written for either three or four voices, and it seems likely that these were originally conceived as elaborations on a chant, normally being placed in these settings as a cantus firmus in long notes in one of the voices (including the lowest voice) in keeping with the practice of contrapunto. Of those included in Tarazona 2/3, all receive major festal designations.

\section{The feast of Corpus Christi}

La Orden provides quite a detailed account of the special rituals and procedures which took place in the royal chapel on the feast

${ }^{101}$ The version of the Estatutos issued during Philip II's reign most clearly expresses this: 'Cuando el Maestro de Capilla . . mandare cantar algún dúo o trío a los dichos, que les fuere mandado, sean obligados de ponerse delante el libro y hacer lo que les fuere mandado, so pena de castigo y ser mutados'; 'Que el verso y Alleluya se digan de aqui adelante cada día como se ha acostumbrada los días solemnes ... y que ninguno ... rehúse de cantar el dicho dúo o trío'. See Barbieri papers 2, doc. 136, items 13-14.

This contrapuntal idiom complements the type published in the Lyons Contrapunctus (1528), a cycle of polyphonic settings of chant mass propers. See The Lyons Contrapunctus (1528), ed. D. A. Sutherland (Recent Researches in the Music of the Renaissance, 21; Madison, 1976).

102 Barcelona, Biblioteca Central, MS 454; Tarazona, Archivo Capitular de la Catedral, MS 2/3; Segovia, Cathedral, Archivo Musical, MS s.s.; and Coimbra, Biblioteca Geral da Universidade, MS 12. See Knighton, 'Music and Musicians', pp. 175-7. Several Alleluia settings are also included in Porto, Biblioteca Pública Municipal, MS 40. I would like to thank Owen Rees and Michael Ryan for providing me with transcriptions of selected Alleluia settings found in Portuguese manuscripts.

${ }^{103}$ See R. Stevenson, 'Escobar, Pedro de' and 'Peñalosa, Francisco de', in The New Grove Dictionary, vi, p. 243 and xiv, p. 347. Tarazona 2/3 also includes six Alleluia settings attributed to an Alonso de Alva. For the possible identity of Alva, who was either sacristan at the Castilian royal chapel in the early sixteenth century or maestro de capilla at Seville Cathedral (d. 1504), see Knighton, 'Music and Musicians', pp. 249-50. 
of Corpus Christi, beginning with the vigils on Wednesday. ${ }^{104}$ It is evident that this feast and its Octave were marked by considerable musical elaboration, and this description once again underlines Aguirre's awareness of the close correlation between liturgical acts and the timing of musical items, particularly with regard to the structure of the texts (or verses) being sung. At sung mass ('Missa cantata') ${ }^{105}$ on the vigils, the celebrant consecrates one more host ('forma') than is needed, and after mass places it in the monstrance which he will use to bless the people. Although an exact choreography of ensuing events is not given in the text, the rituals surrounding what must have been a splendid procession of the monstrance to the place reserved for it, perhaps a special side altar, may be interpreted as follows. While the priest, followed by the king and other members of the court holding white candles, processes, blessing the people with the monstrance, the singers sing Tantum ergo and Genitori genitoque, the final two verses of the Corpus Christi hymn Pange lingua. When the phrase 'Sit et benedictio' (in the verse Genitori genitoque) is reached, the priest carries the monstrance to its resting place. During this ceremony there are 'many torches, incense and bells' (presumably small hand bells), and the monstrance is incensed three times every time it is raised or lowered by the priest. Aguirre then describes how at Vespers, which is attended by the king, the same ceremony takes place but in reverse order. After Vespers, the host is once more taken to its place of repose 'with the same solemnity' where it remains until the following day at Matins when it is taken up again. ${ }^{106}$ The same ritual takes place during the course of the week (the precise number of occasions is not stated), and on the Friday after the Octave, the host is finally consumed by the priest celebrating sung mass that day.

${ }^{104}$ La Orden, fol. $67^{r-v}$. According to La Orden, all the divine Offices were celebrated during the Octave of Corpus Christi, beginning at dawn each day, with the psalms sung alternatim.

${ }^{105}$ It seems likely that Josquin's Missa Pange lingua would frequently have been performed on the feast of Corpus Christi, as also Hotinet Barra's Missa Ecce panis angelorum. Both masses were included in a choirbook in the royal chapel collections, and Barra's mass headed yet another choirbook. See Vander Straeten, La Musique aux Pays-Bas, viii, p. 357.

106 'y acavadas las Visperas le buelven con la misma solemnidad, hasta otro dia a la mañana, que le sacan a los Maytines ...'; La Orden, fol. 67v. There is the implication here that Matins took place in the morning. 
Ritual and Ceremony in the Spanish Royal Chapel, c.1559-c.1561

This is one of the most vividly described ceremonies in La Orden and was one of the high spots on the royal chapel's calendar. The practice of singing verses in honour of the Holy Sacrament during the procession on Corpus Christi and on Maundy Thursday was of course a time-honoured tradition found in churches all over Europe ${ }^{107}$ though the ceremonies in the Habsburg royal chapel probably had far-reaching symbolic intent. ${ }^{108}$ Although the feast of Corpus Christi was first adopted in the Christian Church only from 1317, and soon developed its own ritual and ceremony which spread throughout Catholic Europe, the elaborate ceremonies exercised in the Spanish royal chapel, and then at El Escorial, probably owed much of their origin to the special services venerating the Sacrament which took place in the Burgundian chapel from about the mid-1430s. In 1433 a relic of the miraculous bleeding host was presented by Pope Eugenius IV to Philip the Good, and brought to the Sainte-Chapelle in Dijon. ${ }^{109}$ Barbara Haggh relates that an Office (which unfortunately does not survive) was created for the relic and its veneration, and that 'a sequence for the relic was sung at Masses and processions'. ${ }^{110}$ Such liturgies, including sequences, were once contained in a number of books belonging to the dukes of Burgundy, ${ }^{111}$ and it seems likely that these were absorbed into the rituals of Charles V's royal chapel on his inheritance. According to Tanner, Charles also adopted 'new forms of eucharistic devotion' and even 'established that in pro-

${ }^{107}$ For a full account of Corpus Christi processions in Spain from as early as 1280 (in Toledo), and their very elaborate nature in Barcelona in particular, see $\mathrm{K}$. Kreitner, 'Music in the Corpus Christi Procession of Fifteenth-Century Barcelona', Early Music History, 14 (1995), pp. 153-204.

${ }^{108}$ See M. Tanner, The Last Descendant of Aeneas: The Hapsburgs and the Mythic Image of the Emperor (New Haven and London, 1993), chapter 11, 'The Hapsburg cult of the eucharist', pp. 207-22, for an overview of the history of the Habsburgs' strong devotion to the eucharist which had largely been adopted through the Burgundian-Habsburg dynastic ties.

109 The Sainte-Chapelle in Dijon was both the chapel of the Burgundian dukes since its foundation, and of the Order of the Golden Fleece from 1432. See B. Haggh, 'The Archives of the Order of the Golden Fleece', Journal of the Royal Musical Association, 120 (1985), pp. 1-43, at pp. 24-5.

${ }^{110}$ Haggh, ibid., p. 25 and n. 112. She also says that in 1436 a daily Mass was founded for the relic by King René of Anjou.

111 See Haggh, 'The Archives', p. 25, n. 113, where she also makes reference to C. Wright, Music at the Court of Burgundy (1979), pp. 141, 144-5 and 147. Haggh suggests that a precedent for this may have existed in the Sainte-Chapelle in Paris and its founder King Louis IX (St Louis); ibid., p. 26. 


\section{Bernadette Nelson}

cessions celebrating his military triumphs, the Eucharist would be displayed in a monstrance carried by the archbishop'. ${ }^{112}$ After 1530 Charles V made the feast of Corpus Christi the focus of eucharistic devotion in the Imperial chapel, ${ }^{113}$ a devotion which continued unabated with Philip II. The description of the 1530 Corpus Christi procession in Augsburg led by the archbishop carrying the monstrance, and followed by Charles $\mathrm{V}$ and other royalty carrying white candles, certainly tallies with the account in La Orden, ${ }^{114}$ and has much in common with the ceremony created for another relic of a bleeding host at El Escorial in the seventeenth century. ${ }^{115}$

Although a 'sequence' as such is consistently recorded in the fifteenth-century Burgundian documents, it is not without possibility that the music most frequently sung on these occasions was the hymn Pange lingua adapted by Thomas Aquinas ${ }^{116}$ from the earlier Passiontide hymn of the same name by Venantius Fortunatus. (The verses of the Pange lingua were originally written by Aquinas for the Feast of Corpus Christi when it was instituted by Pope Urban IV in 1264.) In the Leges et constitutiones, which probably has its origins in the Burgundian court chapel of Philip the Fair, it is specifically stated that on occasions of veneration of the Holy Sacrament, the hymn Pange lingua was to be performed in polyphony. ${ }^{117}$ Further, there is evidence dating from the seventeenth century that on the feast of Corpus Christi at El Escorial at least the verse Tantum ergo was sung during the procession. ${ }^{118}$ No mention is made of the organ's role in either La Orden or the Leges, but

112 Tanner, The Last Descendant, p. 214.

113 Ibid., p. 215. For a vivid description of the 1530 ceremony and procession which took place in Augsburg, including indications of the participation of musicians, see Sandoval, Historia, ii, pp. 396-8.

$11+$ See La Orden, fol. 68.

${ }^{115}$ For an account of the origin of the special ceremony created for the sacred relic of a bleeding host ('sagrada forma') at El Escorial in the late seventeenth century, a relic which had been in the possession of Philip II since 1594, see E. J. Sullivan, 'Politics and Propaganda in the Sagrada Forma by Claudio Coello', Art Bulletin, 68 (1985), pp. 243-59, at pp. 251-4, and Noone, Music and Musicians, pp. $160 \mathrm{ff}$., where several other bibliographical references are given.

116 Aquinas was a friend of St Louis, founder of the Sainte-Chapelle in Paris (see above).

117 The whole passage reads: 'In supplicationibus Venerabilis Sacramenti, hymnum $\mathrm{Pa}(\mathrm{n})$ gelingua musicae, et statio ante altare motetum in honorem Venerabilis Corporis Christi, et si non sit statio, illud motetum in ecclesia in quam defertur Venerabile Sacramentum et responsoria et versiculos, cantores in fabordon canunto' (Leges et constitutiones, clause 29).

${ }^{118}$ See Noone, Music and Musicians, pp. 171-7. 
Ritual and Ceremony in the Spanish Royal Chapel, c.1559-c.1561

evidence again of customs enacted at El Escorial would suggest that Charles V's famous portative organ made of silver was frequently used on such occasions, and would have been played perhaps in alternation with the choir or solo to accompany the protracted procession and ceremony. ${ }^{119}$ It is likely that in Philip II's chapel the settings attributed to Antonio de Cabezón would have been used on these occasions. ${ }^{120}$

\section{Holy Week}

The sequence of rituals and ceremonies characterising Holy Week, one of the most highly charged and solemn seasons of the liturgical year, was evidently undertaken with extreme care and precision at the royal court and chapel; it was also a period when the monarch almost invariably retired to the peaceful environment of a monastery, with members of his court and chapel in train. ${ }^{121}$ It is striking how on these and other important festal occasions in the year both Charles V and Philip II frequently chose the seclusion of monasteries of the Jeronymite order, a religious house for which the Spanish royal family had strong affection. ${ }^{122}$ The account of Philip II's sojourn at El Escorial during Holy Week in 1587, for instance, provides ample evidence of the King's participation in the ceremonies, and even his involvement in the choice of musical elaboration; but it also indicates his assumption of a more humble and pious role appropriate to the monastic environment. ${ }^{123}$ Inevitably the whole of the Lenten season was marked by special practices and rituals in the royal chapel, and La Orden gives some

${ }^{119}$ See Sullivan, 'Politics and Propaganda', p. 245, and Noone, Music and Musicians, p. 171.

${ }^{120}$ Evidence for the the organ's role in providing renderings of the Corpus Christi hymn Pange lingua is widespread in Iberian sources, and the version of the hymn tune used at the Castilian court would certainly have been the one commonly identified as 'more hispano'; it is a matter of some interest whether this tune was familiar in the Imperial chapel and whether indeed the famous setting by Juan de Ureda (Johannes Wreede) was regularly sung there.

${ }^{121}$ See Kamen, Philip of Spain, pp. 89 and 102.

${ }^{122}$ In the mid-sixteenth century, these orders were chosen for the foundation of the royal monasteries at Yuste and El Escorial, and a decade or so earlier in Valencia following the obit request made by Queen Germana, consort of the Duke of Calabria, and formerly of King Ferdinand. See B. Nelson, 'A Choirbook for Don Fernando de Aragón, Duke of Calabria: The Sacred Repertory in Barcelona M.1166/1967', in Actas del Coloquio internacional: fuentes musicales en la Península Ibérica, ca. 1250 - ca. 1550 (Lleida, 1999) (forthcoming).

${ }^{123}$ See Noone, Music and Musicians, pp. 91-2. 


\section{Bernadette Nelson}

indication of the distinctions to be made between this season and others in the liturgical year: these include changes in times for celebrating Vespers and Compline on Sundays during Lent, and how this might affect whether a motet was to be sung at Vespers, and the apparent increase in the number of days in which sermons were to be preached. Table 3 comprises a summary of the information provided about the season of Lent, up to and including Easter.

Characteristically, information about the liturgy of Holy Week, rituals and the timing of various of the offices in La Orden may be found in a number of different places in the document, in addition to the main section headed 'Tenieblas' (Tenebrae). ${ }^{124}$ In this section, Aguirre provides one of the most significant details about musico-liturgical practice in the Spanish royal chapel concerning the performance of the Lamentations (presumably referring to those of Matins for Maundy Thursday). Here he writes, 'The Lamentations are normally "said" with four biolones and four voices: tiple, contralto, tenor and contravajo ${ }^{125}$ and the lessons [are said] by the chaplains', the latter indication very probably referring to the practice of chanting the lessons on a reciting tone. ${ }^{126}$ In the light of Robledo's study on the use of bowed stringed instruments at the royal court, this reference is clearly important, and may even be the earliest such record. ${ }^{127}$ According to Robledo, the first documented use of the violones during Holy Week at the royal chapel dates from as late as 1601, although the earliest use of the word violon occurs in the 1559 inventory of Mary of Hungary. ${ }^{128}$ However, it is probably pertinent that the term became more frequent in documents after the arrival of Elizabeth de Valois at court in the

${ }^{124}$ For the section concerned with Holy Week practices beginning with Tenebrae on the Wednesday, see $L a$ Orden, fol. $70^{r-v}$. It begins by stating that Tenebrae only began at the moment the king made his appearance.

${ }^{125}$ Information about which sets of Lamentations formed part of the royal chapel repertories is wanting; these may have included those composed by Pierre de La Rue in 1509, for instance, and later those by Morales (see also below).

${ }^{126} \mathrm{La}$ Orden, fol. $70^{\mathrm{v}}$. The practice of reciting the lessons in chant was common practice in important foundations; similar indications of performance in the lessons of Matins are also described in the documents in connection with Matins on vigils for the dead; see below, pp. 155-8.

${ }^{127}$ See L. Robledo, 'Vihuelas de arco y violones en la corte de Filipe III', Actas del Congreso Internacional celebrado en Salamanca, 29 de octubre-5 de noviembre de 1985 (Madrid, 1987), pp. $63-76$.

${ }^{128}$ Ibid., p. 64 . 
Table 3 Liturgical customs during the season of Lent, up to Easter

Ash Wednesday (La Orden, fols. 78v-79)

The ashes are blessed at low mass in the morning.

The King is blessed with the ashes as the prelate circulates wearing his rochet, then the ashes are administered to all those who wish to receive them, beginning with the nobility.

The King, Queen, Prince and Princess are offered the Gospel blessing and kiss of peace; Don Juan de Austria is excluded from this ceremony.

Sundays during Lent (ibid., fols. 65, 70, 79)

Sermon at mass.

Vespers and Compline to take place in the afternoon.

No motet at Vespers if this is celebrated prior to dining.

Every day during Lent (ibid., fol. 70)

Sermon at mass when sufficient number of preachers are available.

Palm Sunday (ibid., fols. 67v, 68 )

Processsion.

Episcopal blessing of the palms. (Prelate does not say mass this day.)

[St Matthew Passion]

(Sermon at mass)

(Torches at the Gospel and the Elevation)

Wednesday of Holy Week (ibid., fol. 70)

Tenebrae commmences when the King makes his appearance.

Low mass in the morning (with sermon)

Maundy Thursday (ibid., fol. $70^{\mathrm{v}}$ )

Mandatum normally preached at mass at the time of the sermon. (Advertencia, Barbieri papers 2 doc. 135[c])

Ceremony of the washing of the feet of 13 'pobres' (poor people) by the King, and their feeding and clothing.

[Maundy Thursday to Holy Saturday] (La Orden, fol. $70^{\mathrm{v}}$ )

Lamentations: normally performed by 4 singers (tiple, contralto, tenor, contravajo) and 4 violines.

Lessons recited by the chaplains.

Good Friday (ibid., fols. $69^{\mathrm{r}-\mathrm{v}}, 70^{\mathrm{v}}$ )

[St John] Passion to begin at 7 p.m.

Adoration of the Cross beginning with the priest, the deacon and subdeacon, the apostolic delegate, and then the rest of the chapel officers, the King and his court.

When there is a relic of the True Cross in the palace, this is always to be used for the adoration ceremony.

Easter Day ('Primer dia de Pascua de Resurreción') (ibid., fols. 65, 68v)

Pontifical mass (only the King is incensed)

(Torches at the Gospel and the Elevation)

Offerings.

Easter Monday ('Segundo dia de Pascua de Resurreción') (ibid., fol. 70) Sermon at mass. 
beginning of 1560 , even though the instruments did not apparently feature in the lists of salaried musicians. ${ }^{129}$ At what point this performance record was entered into the main body of $L a$ Orden is impossible to gauge, though it is possible that the four players of the vihuela de arco recorded in Charles V's court chapel in at least 1556 played in the chapel services. ${ }^{130}$

No other details of observances on Maundy Thursday are provided in La Orden itself, but in the late copy of the descriptive Advertencia de lo que se executaba en la Capilla found in the Barbieri papers, which is clearly derived from a portion of the $1545 \mathrm{El}$ Etiqueta (see above), ${ }^{131}$ is included a description of the Mandatum ceremony enacted by both the Emperor and Philip II. Headed Lavatorio de Jueves Santo, the passage describes how the king (Charles V) 'when he was in good health and residing in Spain' performed a ceremony which was both a symbolic re-enactment of Christ's actions at the Last Supper and an act of charity. According to this account the king washed the feet of thirteen poor people ('pobres'), and fed them, serving each of them with a plate of food and a goblet of wine which he poured himself. The text relates how during Charles V's time the thirteenth person, representing Judas, was set at a table apart from the other twelve, who sat together on one side of the other table. (During Philip II's time, all thirteen sat at the same table.) After they had finished eating, the king gave them woollen cloth and linen with which to garb themselves and a gold sovereign inside a small bag. ${ }^{132}$ Such

${ }^{129}$ Ibid., p. 65. Robledo omits a further reference to the use of violones in sixteenth-century Spain: in her Memoirs, Marguerite de Valois refers to a mass she attended while she was in Madrid in 1577, even calling it 'une messe à la façon d'Espagne avec musique, violons et cornets'. R. Stevenson, Spanish Cathedral Music in the Golden Age (Los Angeles, 1961), p. 341, n. 152.

${ }^{130}$ See Vander Straeten, La Musique aux Pays-Bas, vii, p. 360, and Robledo, 'La música en la corte Madrileña', p. 787.

${ }^{131}$ These documents are edited in Barbieri papers 2 (doc. 135[c]) and in Vander Straeten, La Musique aux Pays-Bas, vii, pp. 401-3, where they are headed 'Oficios del culto divino'. For details of these documents, see Appendix 2.

132 'Lavatorio de Jueves Santo. Cuando S.M. tenía salud y se hallaba en España, daba de comer el Jueves Santo a 13 pobres, y les lavaba los pies y servía él mismo a cada uno trece platos de vianda, sin la fruta de principio y postre, y echaba vino en sus copas; el treceno pobre se ponía en una mesa aparte, representando el lugar de Judas y los otros doce pobres se ponían juntos al mismo lado en otra mesa, y después que habían acabado de comer, Su Majestad les daba a cada uno paño y lienzo para vestirse y un escudo en un bolsillo, pero el Rey nuestro señor D. Felipe Segundo, (Dios lo guarde), sienta todos trece a una mesa.' Barbieri papers 2, doc. $135[\mathrm{c}]$. 
Ritual and Ceremony in the Spanish Royal Chapel, c.1559-c.1561

distributions to the poor also apparently took place on 'Pascuas' (i.e. Easter, Pentecost and Christmas) and other great feasts during the time of Charles V 'in memory' of the the plate of food which was offered to the poor by the dukes of Burgundy on similar occasions. ${ }^{133}$ The custom of the King perfoming the Mandatum ceremony on Maundy Thursday was retained on his attendance at Holy Week services at El Escorial, but no other symbolic actions such as the feeding of the thirteen poor seem to be recorded. ${ }^{134}$

\section{Good Friday and the veneration of the Holy Cross}

La Orden appears to be the only constitutional document dating from the time of the Habsburg monarchs to bear witness to the special rituals focusing on the veneration of the Cross both on Good Friday and on 3 May, the feast of the Invention of the Holy Cross. (No mention, however, is made of the feast of the Exaltation of the Cross on 14 September.) The significance of these feasts at the royal court was intimately bound up with the Habsburg faith in the Holy Cross to ward off the infidel and as a symbol of their mission as world leaders. ${ }^{135}$ Both monarchs had significant collections of crucifixes, including relics of the True Cross, and La Orden tells us that such a relic was always to be taken out for the Good Friday service whenever possible, as also on the feast of the Invention of the Holy Cross. ${ }^{136}$ In time-honoured tradition, the veneration of the Holy Cross on Good Friday took place after the recitation of the Passion which, as stipulated in La Orden, was to begin at 7 p.m. ${ }^{137}$ The text lists the prescribed order in which members of the clergy should worship the cross as follows: behind the priest officating, and the deacon and subdeacon, should follow the apostolic delegate (if he is present), then the bishops, the chap-

133 This is described in the passage outlining the duties of the mozo de limosna (almoner's assistant) in the 1545 El Etiqueta. See Vander Straeten, La Musique aux Pays-Bas, vii, pp. $400-1$.

${ }^{134}$ See Noone, Music and Musicians, p. 92.

${ }^{135}$ See Tanner, The Last Descendant, ch. 10, 'Fidecrucem: The Hapsburg Veneration of the Cross', pp. 183-206.

136 'Siempre que hay palo de la vera Cruz en Palacio le ponen este dia para la adoracion. En la fiesta de la Cruz que se celebra a tres de Mayo sacan al altar la Cruz con el vero palo'; La Orden, fol. 69v.

137 'La Passion el viernes a las siete, y acavada se comienza el Officio'; La Orden, fol. 70v. This instruction occurs outside the description of the ceremonies on Good Friday. 
lains, the singers and other chapel officers. This group should be followed by the king, then the ambassadors, the grandees and the knights. ${ }^{138}$

There are no references in the documents to the music which might have been performed on these days. However, judging from the number of extant choirbooks copied at El Escorial in the early seventeenth century, repertories which one may assume owed much of their origins to those of the royal chapel (at least from the last few decades of the sixteenth century), polyphonic music performed a vital role in the elaboration of the liturgy and the liturgical Word during Holy Week: as many as seven of the fifteen choirbooks identified by Noone as having been copied in the early seventeenth century for El Escorial comprise, or include, music for the Lenten season and Holy Week. ${ }^{139}$ Among these repertories are eight sets of Lamentations and a large series of Passions, or parts of Passions (turbae), though some of this music was newly composed at El Escorial in the late sixteenth century. Needless to say, this royal monastery was an inevitable home for the choral repertory from about the mid-1560s, which may partially explain why Holy Week music is apparently only scantily represented in the royal chapel inventories. ${ }^{140}$ It is almost impossible to tell which of these pieces would have been performed regularly by Philip II's capilla in the middle decades of the sixteenth century, but among the earlier repertories copied at El Escorial are Jan Nasco's setting of the St Matthew Passion ${ }^{141}$ and a set of Lamentations by Morales. A search for more details of Holy Week music in the midsixteenth century royal chapel, however, will remain inconclusive until more precise data comes to light.

138 'Adoracion de la Cruz en el Viernes Sancto', La Orden, fol. $69^{r-v}$.

${ }^{139}$ For inventories and descriptions of these manuscripts, see Noone, Music and Musicians, pp. 191-245. The seven choirbooks are EscSL 1, EscSL 4, EscSL 5, MontsM 750, MontsM 751, NYorkH 278 and NYorkH 288.

${ }^{140}$ None of the Holy Week items listed on the royal chapel inventories provides any indication that these were polyphonic repertories; rather, the 'Libros passionarios' and other Holy Week 'offices' would appear to be books of chant, many of which were printed. Among the manuscript items were included an unspecified number of 'Libros passionarios de canto' copied by the royal scribe Pompeyo de Russi, who had earlier been employed as scribe at the court and royal Jeronymite monastery (San Miguel de los Reyes) of Fernando de Aragón, Duke of Calabria, in Valencia. See Nelson, 'A Choirbook for the Chapel of Don Fernando de Aragón'. See also Appendix 5.

141 The Passion is copied anonymously into the Escorial manuscripts (e.g. NYorkH 288), but was identified by Greta Olson in her paper 'Some Clues to the Transmission of an Unusual Passion Setting' given at the Sixth Biennial Conference on Baroque Music, 
Ritual and Ceremony in the Spanish Royal Chapel, c.1559-c.1561

\section{Royal anniversaries and commemorations}

In addition to the major feasts on the liturgical calendar, probably the most important events celebrated in the royal chapel were the royal anniversaries and commemorations. These took place at regular intervals throughout the calendar year, and La Orden gives clear references to at least four significant anniversaries associated with Philip II and his parents: the commemorations of the deaths of Empress Queen Isabella on 1 May and Charles V on 21 September, the anniversary of the birthday and coronation of Charles V on the feast of St Matthias (24 February), and Philip II's own birthday on 21 May. By $c$. 1560, the anniversaries of Maria of Portugal, Philip's first wife who died on 12 July 1545, Mary Tudor and Mary of Hungary, both of whom died in November 1558, would have been added as these were absorbed into the yearly run of commemorations at El Escorial a few years later. ${ }^{142}$ The Spanish royal court also had a history of observing exequies and funeral rites over a protracted period of time. For instance, Philip II's request in his Will that the day of his death should be succeeded by a period of nine days during which a daily mass was to to be offered for the repose of his soul had a precedent in the observances surrounding the deaths of his fifteenth-century predecessors. ${ }^{143}$ La Orden also stipulates that the Empress was to be remembered in a said or low mass ('Missa resada') each day of the year, as one of the two low masses which were apparently celebrated on a daily basis:

Each day two low masses are said: one in the palace for the Empress, and the other for the saint of the day in accordance with the rule of the Old Roman

University of Edinburgh, 9 July 1994. It was previously known and performed at the court of the duke of Calabria in Valencia before 1550. See Nelson, 'A Choirbook for the Chapel of Fernando de Aragón'.

${ }^{142}$ See Noone, Music and Musicians, p. 41 (Table 2.1). At El Escorial, Empress Isabella was also commemorated on 24-5 October.

143 'Item mando que el dia de my falecimiento, y los nueve dias sequientes diga Missa por mi alma ...'; Testamento de Philippe $2^{\circ}$, P-La 51-VI-35, fol. 3. Enrique IV's funeral in 1474 was characterised by a nine-day period, and Juan II's funeral in 1479 by one of eleven days; see G. Wagstaff, 'Music for the Dead: Polyphonic Settings of the Officium and Missa pro defunctis by Spanish and Latin American Composers before 1630' (Ph.D., University of Texas, 1995), p. 112. 


\section{Bernadette Nelson}

Calendar. But on Thursdays, Fridays and Saturdays, when the saint has no particular office, [mass] should be said of the Holy Sacrament, of the Cross, and of Our Lady. ${ }^{144}$

The choice of commemorations for the last three days of the week here has many similarities with the series frequently found in royal foundations in the fifteenth and sixteenth centuries both in Spain and in the Burgundian court. ${ }^{145}$ Again, it is probable that this list was augmented by $c .1560$, with prayers added for other deceased members of the royal family; a similar procedure of low masses characterised commmemorations at El Escorial. ${ }^{146}$

Funeral rites and ceremonies were almost invariably preceded by elaborate preparations and marked by considerable pomp and ritual. Seemingly both the Burgundians and the Spanish had a tradition at royal funerals of erecting vast catafalques and 'chapelles ardentes' which formed a spectacular theatrical backdrop to the splendid but solemn processions involving hundreds of lighted candles and torches, and the rituals and ceremonies integrated into celebrations of the vigil offices and the Requiem mass the following day. ${ }^{147}$ Further, the church or chapel would have been completely draped with black velvet, much in the style depicted in a surviving sketch of the Portuguese royal chapel interior in 1649. ${ }^{148}$ Elaborate exequies were not necessarily confined to the place where the body itself lay in state, but may also have taken place in various parts of the kingdom. ${ }^{149}$ In November and December

${ }^{144}$ La Orden, fol. $63^{v}$. According to the Constituciones para el Real Colegio de Cantores de la Real Capilla (Barbieri papers 2, doc. 157), these would have taken place shortly before High Mass.

${ }^{145}$ An example is the weekly series of masses instituted by Philip the Good at the SainteChapelle in Dijon. In this case, the masses on the last three days of the week were of the Holy Ghost, the Holy Cross and Our Lady. See Prizer, 'Music and Ceremonial'. p. 116. For her obit, Queen Germana, consort of the Duke of Calabria, specifically requested masses for the Virgin, the Holy Name of Jesus and the Passion. See Nelson, 'A Choirbook for the Chapel of Fernando de Aragón'.

${ }^{146}$ Noone, Music and Musicians, p. 41 (Table 2.1).

${ }^{147}$ For example, see J. Anderson, “Le roi ne meurt jamais": Charles V's Obsequies in Italy', in El Cardenal Alburnoz y el Colegio de España (Studia Albornotiana, 36; Bologna, 1979), pp. 379-99.

${ }^{148}$ See B. Nelson, 'A Plan of the Capella Real, Lisbon, in 1649', Revista Portuguesa de musicologia, 8 (1998) (in press).

${ }^{149}$ See C. M. N. Eire, From Madrid to Purgatory (Cambridge, 1995), p. 287. 
1558, for instance, Philip II organised a series of ceremonies in Brussels in honour of Mary Tudor and Mary of Hungary, and, on a separate occasion, of his father, ${ }^{150}$ and several exequies took place all over Spain following the death of Philip II in October 1598. ${ }^{151}$ There is little doubt that many of the ritualistic elements of these special events were re-enacted at each anniversary. We have already alluded to the tradition of the king presenting a bag of gold coins at the Offertory on the anniversary of the Emperor's birthday and that of Philip II himself; likewise, La Orden is singular for giving us insight into a ritual enacted by the king during the Offertory of commemoration masses for the Empress Isabella and the Emperor on the anniversaries of their respective deaths (1 May and 21 September). On these occasions the king (and possibly other members of the court) made an offering of a gold coin, at the same time carrying a candle in which was probably embedded a gold coin bearing the royal insignia, comparable to the custom enacted during the Requiem mass at meetings of the Order of the Golden Fleece (see below). ${ }^{152}$ In the summary of procedures for the commemoration of the Empress on the anniversary of her death Aguirre relates: 'At mass, His Majesty offers a gold coin and a wax candle in which [the arms] is embedded; after mass [there is] a sung response. The same [at mass] for the Emperor on the twenty-first of September'. ${ }^{153}$ During the obsequies for Philip II at Zaragoza in October 1598, a similar ritual took place at mass: on this occasion twenty-four citizens came forward at the Offertory

${ }^{150}$ For an account of the exequies for Charles V on 29 December 1559 which took place in Sainte-Gudule, Brussels, see Anderson, "'Le roi ne meurt jamais"', pp. 383-4.

${ }^{151}$ For an account of the ceremony for Philip II which took place in Madrid in October 1598, see Eire, From Madrid to Purgatory, p. 291, and L. Robledo, 'Questions of Performance Practice in Philip III's Chapel', Early Music, 20 (1994), pp. 199-2 18, at pp. 204 and 209-12. For that which took place in Zaragoza, see Juan Martínez, Relación de las exequias (Zaragoza, 1599); a study of this document is currently in preparation by the present author.

${ }^{152}$ It would seem that the scribe of the Ajuda Library document La Orden inadvertently omitted the words un escudo in this clause, such as characterises the entries describing the offerings made at mass on the feast of All Souls and at the Requiem mass during meetings of the Order of the Golden Fleece (see also above, 'The Offertory').

${ }^{153}$ The original passage in La Orden referred only to the vigils and mass to be celebrated on the anniversary of Queen Isabella: 'Cabo de Anno por la Emperatriz Nuestra Señora' (La Orden, fol. 71). 
holding black lighted torches, each containing a gold coin as was 'customary in similar acts'. ${ }^{154}$

From the liturgical point of view, the focus in funerals and commemorations held in the royal chapel was on the vigils, comprising first Vespers, Matins and Lauds, and on the mass for the Dead the following day; but, within that framework, we learn that there was considerable variation according to the category of commemoration. The documents are quite specific about this even though they are lacking in more detailed prescriptions, and there is some correlation between information provided at various junctures in La Orden and the series of clauses relating to commemorations in the Leges. However, discrepancies regarding the structure of Matins on the various occasions make it difficult to gauge which was the norm. The principal differences to be found concern the number of Nocturns to be said (or sung): either the standard three, comprising nine lessons therefore, or just one Nocturn (probably the first), with three lessons. In the section 'Obequies for the death of kings, princes, or infantes' La Orden describes how, while Vespers and 'vigils' (no further details are provided) are to be conducted by a prelate, as many as three pontifical masses were to be celebrated on the day itself ('otro dia'), provided that there were bishops and abbots available: the first mass of the Holy Spirit, the second of the Blessed Virgin Mary, and the third of the dead (a Requiem mass) for which the king made his appearance (the first two masses were celebrated prior to his arrival). ${ }^{155}$ The tradition of celebrating these particular three masses on such occasions was long established in a number of European courts and confraternities from at least the fifteenth century, and indeed obtained for the funerals of Charles V in 1558 and Philip II in 1598. ${ }^{156}$ The

154 'Al tiempo de ofrecer, aviendose sentado, en medio del Altar, en su silla, el Arçobispo, se levantaron veynte y quatro ciudadanos, y llevando cada vno vna hacha negra encendida, y en cada vna, vna pieça de a quatro de oro, ofrecieron, como es costumbre en semejantes actos ...'; Martínez, Relación de las exequias, p. 176.

${ }^{155} \mathrm{La}$ Orden, fols. $66^{\mathrm{v}}-67$. This indication of the king's appearance only at the Requiem mass tallies with Wagstaff's findings of procedures in other sixteenth-century exequies: 'the dignitaries arrived only for the last of the three; it was then that the candles were lighted, and the lavish ceremony began'. See Wagstaff, 'Music for the Dead', p. 92, n. 32.

${ }^{156}$ See Haggh, 'The Archives', p. 10. Haggh also lists such observances for the funeral rites of King Francis I in 1547 and Charles V in 1558 (ibid., n. 47). For Philip II's funeral rites see Robledo, 'Questions of Performance Practice', p. 211. 
same stipulation is made in the Leges for deaths of the king, the queen, or other members of the Austrian royal family, and here it is indicated that the third should be a solemn sung mass for the Dead. This text also gives an indication of a performing pattern of the nine lessons of Matins on these occasions in which the first lesson (in each Nocturn) was to be sung by a solo choirboy, and the rest by the chaplains. ${ }^{157}$

For the offices in honour of the Empress on the anniversary of her death on 1 May, a slightly different scenario is outlined. Here, La Orden states that the vigils, which began after Vespers for Saints Philip and James (whose feast coincided with her anniversary), were to include three Nocturns (i.e. a full-length Matins) and Lauds, but just one mass is indicated for the following day (presumably the Requiem mass) during which a coin and a candle were offered; the only specific reference to music concerns the singing of a responsory after mass. The same structure obtained for the Emperor's anniversary on 21 September. ${ }^{158}$ In the Leges, conversely, exequies for the Emperor, the Empress, and other members of the royal family were to comprise Vespers, but Matins with only one Nocturn, and again a solemn mass concluding with a sung responsory. Here a more specific performing performing pattern for the three lessons is provided: as indicated on other occasions, the first was to be sung by a solo choirboy, but the second was to be sung in fabordon, ${ }^{159}$ and the third by 'the priests'. ${ }^{160}$

For vigils for the dead in a more general sense, both documents specify a Matins comprising three Nocturns and nine lessons, also

157 'Quando Rex aut Regina, aut quisquam ex familia Austriaca vita fungitur, vigilias mortuorum ix lectionibus quarum, primam puer alius, reliquas capellani, cum laudibus solemniter canunto. Quando Rex aut Regina, aut quisquam ex familia Austriaca vita fungitur, tres missae, prima S. Spiritus, secunda Divae Virginis, solemnitur tercia defunctorum canunto'; Leges et constitutiones, clauses 35-6.

${ }^{158} \mathrm{La}$ Orden, fol. 71.

${ }^{159}$ This direction clearly evinces a widespread tradition for performing the second lesson of the first Nocturn on vigils for the dead. In Victoria's Officium defunctorum written for the funeral rites of the Dowager Empress Maria in 1603, the second lesson only is set polyphonically and in fabordón style. A much earlier fabordón setting of this responsory survives in Coimbra, Biblioteca Geral da Universidade, MS 12. See O. L. Rees, Polyphony in Portugal, c.1530-c.1620: Sources from the Monastery of Santa Cruz, Coimbra (New York and London, 1995), p. 190.

160 'In exequiis Imperatoris, Imperatricis, Regis, Reginae, Principis, dominorum nostrorum defunctorum, vesperas cum uno nocturno et laudes, primam lectionem puer unus, secundam in fabordon, tertiam sacerdos, missam solemniter et deinde responsorium musicae canunto'; Leges et constitutiones, clause 32. 


\section{Bernadette Nelson}

indicating a pattern in which the sequence of lessons was to be led by a solo choirboy. ${ }^{161}$ The only occasion when La Orden specifies just one Nocturn on vigils for the dead occurs in the passage describing procedures for All Saints and for commemorations at meetings of the Order of the Golden Fleece on the feast of St Andrew, also mentioning that 'His Majesty' frequently called for no more than one Nocturn. This particular passage also states that despite the shortening of the office of Matins, Lauds was still to be celebrated: 'On these vigils for the dead, Lauds is always said, even though not more than one Nocturn is said, in the way that His Majesty often requests that not more than one Nocturn is said. ${ }^{162}$ This recommendation for Matins with one Nocturn on the occasion of exequies for knights of the Order of the Golden Fleece, as well as Lauds, also occurs in the Leges. ${ }^{163}$ Information about the different categories of commemorations and the varying structures of Matins found in the royal chapel documents is summarised in Table 4; for liturgical offices for meetings of the Order of the Golden Fleece on St Andrew's day see below, Table 5.

While these royal chapel documents do not expound on the office of Vespers on vigils for commemorations, considerable emphasis is placed on Matins which, as outlined above, was frequently coupled with Lauds. Like the majority of other offices celebrated in the Spanish royal chapel, the ceremonial aspect and format of these particular services during the time of Charles V and Philip II had features in common with traditions of royal commemorations in various European courts and churches with royal foundations. Bearing in mind the probable origin of the Leges et constitutiones in the court of Philip the Fair or even earlier, it is notable that the two structures of Matins were usually referred to by the number of lessons involved, this calling to mind the designations of 'feasts of nine lessons' and 'feasts of three lessons' found in the liturgical calendar at Notre-Dame in Paris. ${ }^{164}$ Further, the practice of differentiation in the 'performance' of the successive lessons comprising a Nocturn, which characterises their descrip-

\footnotetext{
${ }^{161}$ La Orden, fol. 70v, and Leges et constitutiones, clause 34.

${ }^{162}$ La Orden, fol. 66.

163 'In exequiis equitum Aurei Velleris, tres lectiones et laudes canuntur'; Leges et constitutiones, clause 33 .

${ }^{164}$ See Wright, Music and Ceremony, p. 74 and passim.
} 
Ritual and Ceremony in the Spanish Royal Chapel, c.1559-c.1561

Table 4 Patterns in vigils, Matins and mass for the Dead

I $L A O R D E N$

Funeral rites for kings, princes or infantes (fols. $66^{v}-67$ )

Vespers and vigils celebrated by one prelate (no other details given)

Three pontifical masses (the next day), provided there are bishops and abbots:

1. Holy Spirit

2. Blessed Virgin Mary

3. Of the dead, for which the king makes his appearance

Anniversary of Empress Isabella, 1 May (fol. 71)

Vigils after Vespers of SS Philip and James (30 April):

Matins with three nocturns and Lauds

Mass (the next day), during which the king offers a gold coin and a candle embedded [with arms or a coin ('un escudo')]

Sung responsory [Ne recorderis] after mass

Anniversary of Emperor Charles V, 21 September

(the same observances) ${ }^{a}$

Vigils for the dead (fol. $70^{v}$ )

Matins [with three Nocturns and nine lessons]:

the first lesson [of each Nocturn] sung by a solo choirboy; the rest by the Chaplains 'de este arte'; the last three lessons [i.e. of each Nocturn] said by the semanero, the subdeacon, the deacon and the celebrant

\section{LEGES ET CONSTITUTIONES}

Funerals of the king, the queen, or deceased members of the Austrian royal family (items 35-6)

Vigils: Matins with three Nocturns \& nine lessons:

the first Lesson sung by a choirboy, the rest by the chaplains

Sung Lauds

Three masses (the next day):

1. Holy Spirit

2. Blessed Virgin Mary

3. Solemn sung mass for the dead

Exequies of the emperor, the empress, kings, queens, princes (item 32)

Vigils: Vespers; Matins with one Nocturn and three Lessons:

1. [Parce mihi] solo choirboy

2. [Taedet animam meam] fabordón

3. [Manus tuae] recited by the priests

Lauds

Solemn mass (the next day), concluding with responsory sung 'in music' [Ne recorderis]

Vigils for the dead (item 34)

Matins with three Nocturns and nine lessons:

the first three [i.e. the first of each set of three] sung by choirboy(s)

a The indication 'lo mismo por el Emperador, al veinte y vno de Septiembre' occurs in the same clause as the description for mass on the anniversary of the Empress (La Orden, fol. 71). 
tion in both La Orden and the Leges, can certainly be linked with services going back to at least the twelfth century in the royal abbey of Saint-Denis in Paris, as also in Notre-Dame. Here, there was a clear correlation between the numbers of officers required to sing certain items and the category or hierarchical importance of the occasion; the increase in numbers of performers required being commensurate with the importance given to the succession of lessons in the Nocturns. ${ }^{165}$ In the Spanish royal chapel the progression through the lessons was marked by contrasting musical forces with, as found in Parisian practice, the sequence of three lessons comprising a Nocturn (in whichever context) invariably beginning with a solo choirboy. It is by no means certain whether these distinctions were invariably upheld in the sixteenth century, and there is already some discrepancy between the patterns recommended on the various occasions in these two documents, particularly for Matins. For Philip II's funeral rites which took place in Madrid and Zaragoza in October 1598, for instance, both occasions entailed a Matins with three Nocturns and Lauds, ${ }^{166}$ which contrasts with the stipulations apparently outlined in the Leges for the funeral rites of kings. Nevertheless, for the Madrid sequence, there is evidence that the lessons in each of these Nocturns were indeed performed first by a solo choirboy, then by four singers in polyphony (presumably fabordón), and third by an honorary chaplain. ${ }^{167}$

In other respects the documents are relatively silent about musical elaborations of offices for the dead, but that these were occasions for considerable participation on the part of the chapel singers is certainly understood by implication. There is a long history of musical performance at commemorations, and Wagstaff puts forward the hypothesis that Spanish royal funerals even took

${ }^{165}$ See A. W. Robertson, The Service-Books of the Royal Abbey of Saint-Denis: Images of Ritual and Music in the Middle Ages (Oxford, 1991), esp. pp. 86-9, and Wright, Music and Ceremony, p. 111. Given that the Burgundian court adhered to the Use of Paris, and in view of the dependency of the legislative structure of the Spanish royal chapel on that of the Burgundian court, it is not surprising that these particular musico-liturgical practices would have been retained.

${ }^{166}$ See Robledo, 'Questions of Performance', p. 209, and Martínez, Relación de las exequias, p. 163.

167 Robledo, ibid. 
the lead in elaborating the services with polyphony. ${ }^{168}$ This was apparently well established by the early sixteenth century, and the ceremonies accompanying the commemoration offices on the anniversary of Philip the Fair's death in 1506 were enacted 'according to the custom of Spain', comprising sung solemn Vespers on the vigil, and a sung Requiem mass celebrated 'with great solemnity' on the day itself. ${ }^{169}$ Nevertheless, the visit of Charles V to Barcelona in 1519 when he both presided over a chapter meeting of the Order of the Golden Fleece and held an elaborate funeral service for Emperor Maximilian, for which music was led by members of his Flemish chapel, was indicative of long traditions likewise enjoyed in the Burgundian court and which would have doubtlessly continued for the succeeding decades of the sixteenth century. ${ }^{170}$ How and when the standard repertories used for funeral rites in the Spanish royal chapel of the Catholic Kings might have merged with those of the Burgundian or Imperial chapel is an issue which begs closer investigation, though it is outside the scope of this study to pursue this in any detail.

${ }^{168}$ Wagstaff, 'Music for the Dead', p. 100, notes that 'there is no documented use of polyphonic music at French or Burgundian funeral services before 1500'. He also cites the instance of Juan II's funeral in 1479 when ceremonial music was sung in 'cant dorgue e contrapunct' (ibid., p. 84 and passim). Bonnie Blackburn, in 'Did Ockeghem Listen to Tinctoris', in Johannes Ockeghem. Actes du XL Colloque international d'études humanistes, Tours, 3-8 février 1998, ed. P. Vendrix (Paris, 1998), pp. 597-640, pp. 623-4, provides important evidence for requests for polyphonic masses in Bruges being made by Spaniards which may, therefore, account for the origin of Ockeghem's setting: 'Ockeghem's Requiem may have originated in a private commission, perhaps a Spanish one. The only requests for polyphonic masses that I know of were made by Spanish merchants and their families in Bruges; if such Requiems came into use in the Low Countries, as we know they did from surviving settings, it was perhaps because of Spanish influence.' I would like to thank the author for bringing this information to my attention.

169 'A veinte é cinco dias del mes de Setiembre deste año se cumplio un año que el Rey don Phelipe muerto habia; é seguiendo la Reina la costumbre Despaña cerca desto, mando decir solemnemente visperas cantadas por el ánima de su marido, y en el seguiente dia con gran solemnidad mandó que se cantase misa y oficios de requiem ...'; passage from an anonymous chronicle, Continuación de la Crónica de Pulgar, cited by Wagstaff, 'Music for the Dead', pp. 288-9 and n. 64. See also Knighton, 'Music and Musicians', pp. 178-9.

${ }^{170}$ See E. Ros-Fábregas, 'Music and Ceremony during Charles V's 1519 Visit to Barcelona', Early Music, 23 (1995), pp. 375-91, at pp. 378-82. His report that the 'official act of the Order of the Golden Fleece stated that funerals as magnificent as that of Maximilian had never been seen in the Spanish kingdom' is intriguing in view of Wagstaff's hypothesis. See ibid., p. 388, n. 16, and above, n. 168. 
There is little doubt that the Requiem mass, the third of the three masses celebrated on royal obsequies, was sung in polyphony. However, only two polyphonic masses from the time of the Catholic Kings and the early sixteenth century are known - the settings by Escobar and Basurto - and these survive as unica in sources preserved in Tarazona. ${ }^{171}$ Wagstaff proposes that these formed part of a long-standing tradition of four-part polyphonic pro defunctis masses peculiar to Spain and the Spanish court, which enjoyed a different or independent line of development from the slightly earlier settings by Dufay and Ockeghem, the first known settings by Franco-Flemish composers. Intriguingly, two items of the proper of the mass composed by Ockeghem and Brumel were copied with the Basurto setting in Tarazona 5, along with other propers by Pastrana and Peñalosa, ${ }^{172}$ and it has been suggested that this composite mass may even have been compiled for the funeral rites of Empress Isabella. ${ }^{173}$ Both Escobar's and Pastrana's pro defunctis masses are found with settings of the responsories $N e$ recorderis and the Libera me attributed to Franciso de la Torre and Anchieta (two composers attached to the court of the Catholic Monarchs) and, judging from other Iberian sources containing Requiem masses, it would seem that these responsories were almost invariably associated with any commemoration, right up to the seventeenth century. One of these sources was copied in El Escorial in 1604 and may well, therefore, be indicative of traditions in the capilla real itself. ${ }^{174}$

It is notable that no complete Requiem masses by composers such as Pierre de La Rue who were associated with the Burgundian or Imperial court chapels have yet been located in Iberian sources, and whether Dufay's (now lost) three-voice setting travelled to

171 Escobar's setting is in Tarazona 2/3, and that by Basurto in Tarazona 5.

172 The portion of the manuscript beginning with Basurto's mass includes settings of the Tract (Sicut cervus) by Pastrana and Ockeghem, the Communion (Luceat eis) by Brumel, the latter probably having been copied from his 1516 publication, and a further settings of the Offertory (Domine Jesu Christe) by Peñalosa. Ockeghem and Brumel are unidentified in the source. See Wagstaff, 'Music for the Dead', pp. 229-50.

${ }^{173}$ This has been proposed by Eleanor Russell, in 'The Missa in Agendis Mortuorum of Juan García de Basurto: Johannes Ockeghem, Antoine Brumel, and an Early Spanish Polyphonic Requiem Mass', Tijdschrift van de Vereniging voor Nederlandse Muziekgeschiedenis, 29 (1979), pp. 1-37, at p. 13. See also Wagstaff, 'Music for the Dead', pp. 230 and 277.

${ }^{174}$ For an inventory and description of this manuscript see Noone, Music and Musicians, pp. 228-31. 
Spain with or after the Emperor's investiture as head of the Order of the Golden Fleece may always remain a matter for speculation. ${ }^{175}$ This lack of knowledge of the polyphonic Requiem masses which may have been regularly performed in the Imperial royal chapel therefore makes it difficult to ascertain which repertories may have been absorbed into the royal chapel on Philip II's accession to the throne, when much of the choice of music in liturgical services would probably have been led by the Flemish maestro de capilla Pierre de Manchicourt and built on the experience of his predecessor Nicolas Payen. Manchicourt copied his Missa de requiem into Montserrat 772 in $c .1560$, and there is a reference to 'some' Requiem masses forming part of a choirbook listed in the royal chapel inventories. ${ }^{176}$ We therefore have no knowledge of the extent to which offices for the dead by Basurto, Pastrana, Escobar or Peñalosa might have been used at royal exequies, though it seems likely that the responsory to be sung after mass on the anniversaries of Empress Isabella and Charles V in La Orden ${ }^{177}$ would have been the $\mathrm{Ne}$ recorderis setting attributed to La Torre, as also the responsory specified in the Leges et constitutiones to be sung 'in music' after mass on these and similar occasions. ${ }^{178}$

\section{The feast of St Andrew and the Order of the Golden Fleece}

One of the most important institutions associated with the Spanish royal chapel was the Order of the Golden Fleece, of which Philip II assumed headship following the abdication of his father as sovereign of the Netherlands and duke of Burgundy in October

175 Dufay's mass was apparently still performed in the sixteenth century, and was requested in endowments at Cambrai in 1517 and as late as 1550. See Craig Wright, 'Dufay at Cambrai: Discoveries and Revisions',Journal of the American Musicological Society, 28 (1975), pp. 175-229, at pp. 219-20, and Wagstaff, 'Music for the Dead', pp. 260-2.

${ }_{176}$ This is a book of nine masses headed by the Missa surrexit pastor bonus, presumably by Lupus Hellinck (only the title is given). See Andrés, 'Libros de canto', p. 156 (item 180), and Vander Straeten, La Musique aux Pays-Bas, viii, p. 380, where the entry is mistranscribed. This is the second of two books containing this mass by Hellinck, the other now identified as MontsM 776 (see above, n. 93).

177 'Acavada la Missa se dize un Responso Cantado'; La Orden, fol. 71.

${ }^{178}$ See above, n. 160. In fact on another occasion, La Orden specifies that the responsory $\mathrm{Ne}$ recorderis should indeed be 'said' (i.e., probably sung) after a Requiem mass: 'Acavando de dizir [sic] la Missa de Requien, dizen un responso Ne recorderis'; La Orden, fol. 63 . 


\section{Bernadette Nelson}

1555. ${ }^{179}$ With Charles V, the system of election of knights to the Order had expanded to include noblemen of Spain and Portugal, as well as other parts of Europe, though this had initially met with some opposition: many Spaniards preferred allegiance to the more ancient Orders of Santiago, Calatrava and Alcántara, and knights of these Orders formed a regular part of the entourage of the Catholic Kings. The chapter in Barcelona in 1519 was the first and only one to take place outside the immediate vicinity of the Burgundian realms, and at the first of this double session, the ten knights named were all Spanish. ${ }^{180}$ In total, of the eighty-two Knights elected at the four official chapters during Charles's term of office between 1517 and 1545, two were Portuguese kings, and just under one-third were Spanish; his son, prince Philip, was elected in 1531 at the age of four. ${ }^{181}$ Philip presided over the last two official meetings, which took place in the Netherlands in 1556 and 1559 before his ultimate return to Spain. However, through chronicles and other contemporary documents we learn that at least investiture ceremonies of newly elected knights continued unabated throughout his reign, one of the last having taken place in Madrid in 1593. ${ }^{182}$

Although the core of La Orden was evidently established during Charles V's reign, it is indicative that in time-honoured custom annual commemorations centred on the feast day of St Andrew (30 November), patron of the Order, complete with solemn vigils, a pontifical mass on the feast day itself, followed by a Requiem mass the succeeding day. ${ }^{183}$ In this sense La Orden is rare among

${ }^{179}$ For a discussion about the Order of the Golden Fleece and its history, see Prizer, 'Music and Ceremonial', and Haggh, 'The Archives of the Order of the Golden Fleece'. Concerning the Golden Fleece and its significance for the Burgundian-Habsburg dynasty, see Tanner, The Last Descendant, ch. 8, 'The Order of the Golden Fleece', pp. 146-61.

${ }^{180}$ It was for the Barcelona session that Charles V's motto Plus ultra was written in Latin for the first time, thus making it more universal; however it was some time before it was adopted globally. See E. Rosenthal, 'Plus Ultra, Non Plus Ultra, and the Columnar Device of Emperor Charles V', Journal of the Warburg and Courtauld Institutes, 36 (1973), pp. 204-28, at pp. 223-4. For details of this meeting, see Ros-Fábregas, 'Music and Ceremony', pp. 375-91.

${ }^{181}$ See Sandoval, Historia, iii, pp. 172-4, which includes a list of all the knights elected by Charles $\mathrm{V}$ between 1517 and 1545 .

${ }^{182}$ See Kamen, Philip of Spain, p. 202.

${ }^{183}$ Saint Andrew was also patron saint of the dukes of Burgundy and of the House of Valois. In the fifteenth century, the feast of St Andrew was frequently celebrated on days earlier in the year when the weather was more clement. See Prizer, 'Music and Ceremonial', p. 115. 
Ritual and Ceremony in the Spanish Royal Chapel, c.1559-c.1561

royal chapel documents, also providing information about the procession and offerings during the Requiem mass of lighted candles embedded with coins, or possibly heraldic devices such as obtained in the Burgundian court (see above). As already suggested, it is likely that the offerings on St Andrew's Day itself consisted of lighted candles and gold coins; no other details about rituals during mass on St Andrew's Day, however, are given. That the 1593 commemoration took place on St Andrew's Day gives some indication that this was at least one Burgundian tradition that Philip II maintained throughout his reign even though he no longer apparently organised a 'grand chapitre' as such. The only other reference to the Order of the Golden Fleece in a royal chapel document occurs in the Leges et constitutiones in connection with funeral rites held for the knights.

The section in La Orden most concerned with the series of liturgical ceremonies associated with the Order of the Golden Fleece on St Andrew's Day is particularly convoluted, and is almost entirely concerned with vigils and the mass for the Dead on the succeeding day. ${ }^{184}$ This was traditionally celebrated in honour of deceased members of the Order of the Golden Fleece, the vigils comprising pontifical first Vespers, Matins with only one Nocturn, and Lauds. ${ }^{185}$ Reference to this mass is made through its association with St Andrew's Day, using the expression 'otro dia' ('otro dia de Sant Andres, y de Diffuntos'). The passage also makes an oblique reference to pontifical vigils and Vespers on the feast of All Saints which, like that on St Andrew's Day itself, was a preparation for the ensuing day's (All Souls) commemoration mass. In his summary concerning these liturgical ceremonies Aguirre shows great concern for correct procedure, and the distinctions to be made with regard to aspects of ritual, liturgy and music, stating how it was the responsibility of the limosnero mayor, the sacristan mayor and the maestro de capilla to ensure that all reflected the pontifical nature of the occasion. Here, reference is made to the sung response after the Requiem mass (though without specifying which

${ }^{184} \mathrm{La}$ Orden, fols. $65^{\mathrm{v}}-66^{\mathrm{v}}$. Details of offerings for these ceremonies are included in the section Offrendas (fols. 68v-69).

${ }^{185}$ Both La Orden and the Leges et constitutiones concur on the format of Matins, with the Leges also indicating that the three lessons should be sung. 
one) ${ }^{186}$ and to the number of torches (four) to be held at the elevation. At the beginning of the section Aguirre gives one significant instruction regarding the response De profundis which, he says, should only be 'said' in connection with a chapter meeting. ${ }^{187}$ According to the original statutes of the Order of the Golden Fleece and other fifteenth-century Burgundian documents, the psalm De profundis was sung at the conclusion of the Offertory procession, the central event in the mass during which 'every knight and participant had a prescribed place and function, with the knights processing with lighted candles'. ${ }^{188}$ It is only further on in La Orden, under the section 'Offerings' (Offrendas), that one learns of the offering of an escudo embedded in a candle in this particular mass: 'Otro dia de Sant Andres con vna vela encendida offrece el escudo hincado en la vela'. ${ }^{189}$

The description of the vigil offices in La Orden is largely made in relation to the celebrant's donning of his cope at various junctures at Vespers, Matins and Lauds, which appear to be defined by the sequence of specific liturgical items - in particular the canticles of Vespers and Lauds, and the Lessons of Matins, all of which were presumably sung. Here another reference to a responsory is made (again unspecified), seemingly at the conclusion of Lauds. Aguirre states that it was only to be said when there was a corpse in the chapel which was to remain there until the conclusion of mass the next day. ${ }^{190}$

Information about the liturgical ceremonies associated with $\mathrm{St}$ Andrew's Day found in La Orden is presented in Table 5. ${ }^{191}$ Much of the procedure resembles that indicated for commemoration masses

${ }^{186}$ It is likely that this was the Ne recorderis, the response traditionally said after Requiem masses as stated earlier by Aguirre (see above).

${ }^{187}$ This instruction follows immediately on from the first reference to a response after the mass as if by association: 'dize el Responso acabada la Missa, y no se dize De Profundis sinó en el Capitulo del Tuson'; La Orden, fol. 65".

${ }^{188}$ See Haggh, 'The Archives', p. 12.

${ }^{189} \mathrm{La}$ Orden, fol. 69. To date, the only other references to this custom of offering a candle with a coin have been encountered in Iberian documents describing royal exequies. These include an account of ceremonies at the ducal palace of the Braganzas in Vila Viçosa, Portugal, of 1600. See J. A. Alegria, História da capela e colégio dos Santos Reis de Vila Viçosa (Lisbon, 1983), p. 33. I would like to thank Michael Ryan for drawing this reference to my attention.

${ }^{190}$ La Orden, fol. $66^{\mathrm{r}-\mathrm{v}}$.

${ }^{191}$ This information has been compiled from various parts of La Orden: fols. 65v-66v 69 and 70, as well as item 33 in the Leges et constitutiones (see above, n. 163). 
Ritual and Ceremony in the Spanish Royal Chapel, c.1559-c.1561

Table 5 Liturgical offices and customs for meetings of the Order of the Golden Fleece on St Andrew's Day

\section{St Andrew's Day (30 Nov.)}

Pontifical mass.

Sermon.

All the knights of the Order of the Golden Fleece to make offerings on this day.

Only the king is administered incense, and no one else, even though the prince is present.

Pontifical first Vespers and vigils for the dead.

Matins, with only one Nocturn [the 3 lessons to be sung], and Lauds.

Response at Lauds only when corpse present in the chapel until the end of mass the next day.

The day after St Andrew's Day ('Otro dia de Sant Andres, y de Diffuntos')

(1 Dec.)

[Requiem] mass

No Gospel blessing or kiss of the pax unless the mass is pontifical.

Offerings: a coin [or arms] embedded in a [lighted] candle.

De profundis is only to be [sung] at the chapter of the Golden Fleece [at the end of the Offertory].

Four torches held at the elevation.

Sung Responsory [Ne recorderis] after mass. No torches are held during the response if there are candles.

for royalty, and Haggh's comment that 'it seems more useful to view the votive masses, and the ceremonies of the Order's meetings, as extensions of the burial or commemorative liturgy typical of funerals of the nobility' is certainly apt, even if based on an earlier context. ${ }^{192}$ However, La Orden provides no evidence for a third or fourth day in this cycle which, in accordance with practices established in the Burgundian court, would have been dedicated to the Virgin Mary and the Holy Ghost respectively, though there is evidence for the celebration of a Marian mass at the 1519 meeting. ${ }^{193}$

Both Prizer and Haggh have successfully demonstrated how the meetings of the Order of the Golden Fleece were occasions of ostentatious display with, by way of long tradition, liturgical ceremonies adorned with vocal polyphony. Chronicles dating from

${ }^{192}$ Haggh, 'The Archives', p. 36.

${ }^{193}$ See Wright, 'Music and Ceremonial', p. 120, and Ros-Fábregas, 'Music and Ceremony', p. 384. Wright indicates that these observances continued in Philip II's time, though he provides no references (ibid., p. 120). 
Philip II's time certainly bear witness to the extent to which these occasions called for the participation of the whole court, no doubt involving considerable expense and painstaking preparation. In Cock's 1585 Relación, for instance, we have evidence of two election ceremonies taking place within a few months of each other (in Zaragoza and Barcelona), and each accompanied by elaborate pomp and ceremony, feasting and general celebration which occupied the court and invited officials and guests for the greater part of the day. Cock describes the dressing of the king's oratory in the church with gold curtains, and the procession to mass of the newly elected knights holding their 'toisones' (special ceremonial collars) in their left hands, with the King bringing up the rear. ${ }^{194}$ The walls of the church were also hung with tapestries and other fabrics in traditional fashion, and the knights would probably have changed their dress each day as appropriate to each liturgical ceremony. ${ }^{195}$ For the meeting on St Andrew's Day in 1593, Kamen refers to how the royal alcázar in Madrid was illuminated and decorated for the brilliant ceremony'. ${ }^{196}$

Glearly polyphonic masses and other vocal settings held a special place in these commemorations, even though the documents both from the Burgundian court and the Spanish royal court provide us with relatively little information. As already indicated, the question of whether or not Dufay's polyphonic Requiem remained in the repertory in sixteenth-century Spain, or any other of the possible commmisions to such composers as Josquin and Agricola for these celebrations, ${ }^{197}$ as yet remains unproven, though music by the latter two composers once formed part of the royal chapel repertories. Similarly, we can only speculate whether Busnoys's L'homme armé mass, or any of the other L'homme armé masses, were regularly performed on St Andrew's Day. ${ }^{198}$ With time, and with

${ }^{194}$ Cock, Relación del viaje, p. 81.

${ }^{195}$ See Prizer, 'Music and Ceremonial', p. 119.

${ }^{196}$ Kamen, Philip of Spain, p. 202.

${ }^{197}$ See Prizer, 'Music and Ceremonial', pp. 129, 133 and passim.

198 The presence of Busnoys's L'homme armé mass in Barcelona 454B (copied some time before 1520) has prompted speculation about its use at the 1519 meeting. See RosFábregas, 'Music and Ceremony', pp. 385-6. For further discussions about the possible connections between masses in the L'homme armé tradition and meetings of the Order of the Golden Fleece, see L. Perkins, 'The L'Homme armé Masses of Busnoys and Ockeghem: A Comparison', Journal of Musicology, 3 (1984), pp. 363-96; Prizer, 'Music and Ceremonial', pp. 128-9, and R. Taruskin, 'Antoine Busnoys and the L'Homme armé Tradition', Journal of the American Musicological Society, 39 (1986), pp. 255-93. 
more archival research, it is possible that the original function of polyphonic masses composed by musicians associated with the court in the early and mid-sixteenth century will be revealed. Listed in the inventory of music books in the royal chapel, for example, is a folio manuscript of just a single six-voice mass by Canis, a member of Charles V's chapel between 1542 and 1555. Though no title is given to this work, the inventory describes how the front cover of the volume portrays two royal coats of arms, one of which includes 'the Fleece' ('el Tusón'). ${ }^{199}$

To conclude, La Orden appears to be the first document encountered which provides relatively elaborate detail about a number of rituals and ceremonies in the Spanish royal chapel of around the mid-sixteenth century, about which little was known previously. Its significance also lies in the fact that it shows how the origin of many of these as well as a few musico-liturgical practices evidently lay in the fifteenth-century Burgundian court chapel and therefore Parisian Usage. ${ }^{200}$ It was written and recopied at a strategic time when the royal court and chapel were in a period of transition, and at the time when when the joint institutions of the capillas flamenca and española really began. It must therefore directly reflect the customs in the royal chapel when Pierre de Manchicourt was elected maestro de capilla in succession to Nicolas Payen, both of whom would therefore have organised the style of musical elaboration to accompany the liturgical and ceremonial acts described here. Though by no means a complete account of proceedings in the royal chapel, it is also unique for having been compiled by a participant of the chapel whose concern for the coordination between the various celebrants and the chapel officers, and notably for that between certain rituals and their accompanying musical items, informs and frequently has a bearing on the way the docu-

199 'Otro quaderno . . . de una missa de música de Cornelio Canis a seis vozes, con dos escudos de las armas reales, el uno con el Tusón y el otro sin él, con un pliego de papel por cuvierta.' See Vander Straeten, La Musique aux Pays-Bas, viii, p. 371 (item 51). There are only two masses extant by Canis, and both are written for six voices. The title of one of these, Missa super 'Salve celeberrima', is suggestive of Marian devotion. See also n. 94 for Manchicourt's masses in MontsM 772.

${ }^{200}$ For information on musico-liturgical practices in the Burgundian and HabsburgBurgundian courts, see M. J. Bloxam, 'A Survey of Late Medieval Service Books from the Low Countries: Implications for Sacred Polyphony 1460-1520' (Ph.D. diss., Yale University, 1987), pp. 67-88. 
ment is presented. It is one of a number of constitutional documents apparently revived at this time and, like the Leges et constitutiones and Charles V's Estatutos, may well have served as a basis for procedure in the royal chapel for several decades to come; no other statutory documents seem to have been issued until the Advertencias of 1584. It is likely that liturgical ceremony remained unchanged for at least the early years of Philip II's reign, though we learn of his active intervention in liturgical matters after the Council of Trent in $c .1565 .{ }^{201}$ In all events, despite the establishment of the court in Madrid in May 1561, Philip was continually moving between royal residences, and Aguirre's remark that ceremonies may vary 'with the times and places where His Majesty travels' no doubt held true throughout his reign. Nevertheless, there is little doubt that the 'diverse ceremonies' described in $L a$ Orden were extremely elaborate and protracted affairs in which ritual, ceremony and musical performance were linked within a coherent and highly programmed structure.

University of Hong Kong

${ }^{201}$ See Kamen, Philip of Spain, p. 105. 
Ritual and Ceremony in the Spanish Royal Chapel, c.1559-c.1561

\section{APPENDIX 1}

Duties and Responsibilities of the Officers of the Capilla Real ${ }^{1}$

\section{Capellan Mayor (First Chaplain)}

Always conducts the Office when he is present in the chapel, unless, for the sake of politeness, another prelate is recommended. In his absence, another prelate resident in the court is to be nominated. He is to appoint a judge amongst members of the chapel when necessary. $\mathrm{He}$ is responsible for the governing and administration of the chapel, and once a month (or more, if necessary) he may hold meetings in his lodgings; with the Receptor he is to conduct ceremonies for new chaplains when they take an oath of allegiance.

He receives distributions for the value of two chaplains.

\section{(Lugar teniente) (Second Chaplain)}

The lieutenant, or second-in-command, performs his duties in his absence.

\section{Limosnero Mayor (Major Almoner)}

Apart from his job as almoner, he is to assist at all Offices in the chapel, and, in the absence of either a prelate or the deacon, he is to administer the Gospel blessing and the pax. He is responsible for the chaplains, singers and other officers who obey him as if he were Capellan Mayor. He is responsible for knowing at what time and in what manner His Majesty would like the Offices to be celebrated. $\mathrm{He}$ is to say the Benedicite and thanksgiving at the King's table. ${ }^{2}$

\section{(Segundo Limosnero) (Second Almoner)}

There is to be a second almoner in the chapel to substitute for the first in the latter's absence. (See also Sumilleres del Oratorio.)

\section{Sacristan Mayor (First Sacristan)}

$\mathrm{He}$ is responsible for preparing the altar. He accompanies the prelate, the Limosnero, deacon or whoever else performs a ceremony. He carries the salver bearing the [missal after the reading of the] Gospel, and the

1 This information is largely taken from La Orden, 'Officiales de la Capilla', fols. $71^{\mathrm{v}}-76$ and other parts of the document. It is augmented by a few details from the 1545 Estriquete $y$ Relascion, the only other royal chapel document to outline the duties of chapel officers. Details of wages found in the Estriquete are omitted on this table.

2 This particular clause lifted from the 1545 Estriquete corresponds with a passage describing the Major Almoner's duties in Olivier de la Marche's Mémoires of the mid-fifteenth-century Burgundian court. See Olivier de la Marche, ed. Beaune and D'Arbaumont, iv, p. 3. 


\section{Bernadette Nelson}

pax; he also accompanies the preachers to and from the pulpit, and the chaplains and singers to and from their places when they go to recite the Lessons.

Sumilleres del Oratorio (Chamberlains of the [Royal] Oratory) There are two who serve on alternate weeks. Their task is to register the missal and the hours, or whatever other book His Majesty must pray from, and to know the hour when the King wants to hear mass. The Oratory chamberlain assists at the canopy, opening it when His Majesty wishes to enter, and then closing it, taking account of the King's wishes. He makes sure that the Mozos del Oratorio are cleanly dressed.

The eldest Sumiller assumes the office of the Limosnero Mayor in his absence.

\section{Receptor (Receiver)}

The receiver of the chapel receives and administers all the distributions offered as admission duty, offerings, legitimations, etc. In the absence of the Capellan Mayor or his deputy, the receiver recommends which prelate and chaplains should take the Office. On Sundays and [major] feasts, the receiver accompanies the prelates who are to offer the 'Gospel' and the pax to the celebrants [to be kissed]. He is responsible for assigning the days for sermons, the weekly masses and other offices of the chapel [to the chaplains]. The receiver is responsible for advising the chaplains; when there are any extraordinary offices in the chapel the receiver takes distributions for [the equivalent] of two chaplains.

$\mathrm{He}$ is to attend ceremonies for new chaplains when they take an oath of allegiance, and collect the entrance fee of 3,000 reis.

\section{Capellanes (Chaplains)}

The chaplains are subject to the Capellan Mayor or his Lugar teniente, or whoever has been appointed as judge by the Capellan Mayor. Unless there is a legitimate excuse, they must never excuse themselves from their week of duty which was assigned to them by the receiver, not must they ever miss offices in their week of duty. They must be in the chapel on Sundays and major feast days especially.

Maestro de Capilla y Cantores (Chapel master and singers)

They must never miss the hours of Office; when a singer fails to appear at the offices, the Maestro de Capilla reproves him and, when pertinent, asks the Limosnero Mayor to admonish him.

The Maestro de Capilla is in charge of the choristers; he feeds and clothes them and collects their wages. He also teaches them music and the liturgical offices. He arranges the mode of transport for the boys when the 
Ritual and Ceremony in the Spanish Royal Chapel, c.1559-c.1561

king leaves the court.

Cantorciços (Boy choristers)

When their voices break, they are sent off to study for three years at the King's expense; if they recover their voices they should normally return to the royal chapel as singers.

They have a Latin tutor.

\section{Mozos de Capilla (Altar servers)}

There are normally four: two to serve at sung masses, and two at low masses. Those serving at sung mass are responsible for preparing the altar in time so that everything is there for the mass.

Mozos de Oratorio (Boy servers of the King's Oratory)

The other two must help at low masses, and prepare the Citial and the canopy in such a way that it is clean and ready when His Majesty appears. After low mass, they must take off the altar cloths and put them in their coffers. This is because it is assumed that the Mozos of sung mass have already completed their task, and collected that which appertains to them.

Mozo de Limosna (Almoner's assistant)

His duty to visit the poor, widows and others, and report their needs to the Limosnero Mayor. He must attend the King's table when he dines in public, and he receives any leftover bread to distribute to the poor.

Furrier de la Capilla (Chapel steward)

His job is to find lodgings for the chaplains, the singers and other officers of the chapel. He must attend all services and, when it is time for them to begin, ring the chapel bell in the corridors or so that those (the chaplains and the singers) wandering in the courtyard can hear and attend the Office. His task is also to assist the chaplains and singers, and fetch a bench from the Furrieria when necessary. Candles and torches are prepared in the Furrieria.

Organista (Organist)

The organist and the organ tuner must be present at the offices when the organ is to be played. Any absences are to be reproved by the Limosnero. 


\section{APPENDIX 2}

Statutes and Other Constitutional Documents ${ }^{1}$

\section{Burgundian court - Charles $\mathrm{V}$}

Ordennances touchant la chapelle (Charles the Bold, 1469). GB-Ob Hatton 13, fols. 10ㄴ47: ed. Fallows, 'Specific Information', pp. 146-59

Statutz et ordennances pour ladite chapelle (Charles the Bold; reissued in 1500 by Philip the Fair). B-Agr, Fonds: Papiers d'État et de l'Audience, reg. 22, fol. 104: ed. Doorslaer, 'La Chapelle musicale', pp. 45-6

Statutz et ordennances sur le faict de nostre grande chapelle (Charles V, 1515). B-Agr, Fonds: Papiers d'État et de l'Audience, reg. 23, II, fols. 10 ff. [seventeenth-century copy]: ed. Schmidt-Görg, Nicolas Gombert, pp. 340-2, and Vander Straeten, La Musique aux Pays-Bas, vii, pp. 278-81

\section{Castilian court}

Constituciones de la Real Capilla de Don Henrique IV (c. 1436). E-Mn MS 14.018/4 (Barbieri papers copied from E-Sag, Archivo de la Real Capilla, Leg. 1, no. 12): ed. Barbieri papers 2, doc. 124

Constituciones de la Capilla Real de Spaña (late fifteenth century: reign of the Catholic Monarchs). E-Mn MS 14.075/12 (Barbieri papers copied from E-Sag Patronato Real, Leg. 25-1): ed. Barbieri papers 2, doc. 126

\section{Charles V}

Estatutos de la Capilla del Emperador Carlos quinto al vzo de la Caza de Borgoña (c. 1518). P-La 51-VI-37, fols. 79v-84 (mid-seventeenth-century copy): ed. below, Appendix 4

Estriquete y Relascion de la orden de seruir q(ue) se tenia en la Casa del Emperador don Carlos n(uest)ro señor el anno 1545. F-Pn, Section des manuscrits, Esp. 364, fols. 2-5: ed. Schmidt-Görg, Nicolas Gombert, pp. 338-40 (= first section of the following documents)

$=$ El Etiqueta. Relacion de la forma de servir, que se tenia en la casa del Emperador Don Carlos, nuestro s(eñ)or, que aya gloria, el año de 1545 y se havia tenido algunos años antes. E-Mpa [n.s.]: ed. Vander Straeten, La Musique aux Pay-Bas, vii, pp. 398-403

1 With the exception of documents found in Lisbon archives, all source references have been taken from the secondary literature cited here or from Robledo's 'La música en la corte de Felipe II' 
Ritual and Geremony in the Spanish Royal Chapel, c.1559-c.1561

= Constituciones que se guardaban en la Real Capilla del Señor Emperador D. Carlos Nuestro Señor, el año 1545. Y se habían observado algunos años antes .... E-Mn MS 1013 (olim cod. E. 76); E-Mn MS 14.018/1 (Barbieri papers copied from 1792 document): ed. Barbieri papers, doc. 135[a-c]

incl.: Ordenanzas pertenecientes a las ceremonias que se mandaron guardar en dicha Real Capilla en lo tocante al culto divino (abbreviated version of Estatutos que hasta agora . . . copied in 1792). Ed. Barbieri papers 2, doc. 135[b]

\section{Charles V and Philip II}

Leges et Constitutiones Capellae Catholicae Maiestatis a maioribus institutae, a Car. Quinto studiosè custodite, hodierno die, mandato Regis Catholici ... (? originated in reign of Philip the Fair (d. 1506); adapted (before 1568) during the reign of Philip II). E-Mpa Administrativa, Leg. 1133: ed. Vander Straeten, La Musique aux Pays-Bas, vii, pp. 183-6; Schmidt-Görg, Nicolas Gombert, pp. 340-2

La Orden que se tiene en los Officios en la Capilla de Su Magestad (drawn up in c. 1550 by Aguirre, chaplain and receiver in the royal chapel; revised and updated in early 1560s). P-La 51-VI-37, fols. 61-79 (mid-seventeenthcentury copy): ed. below, Appendix 3

Constituciones o estatutos de la Real Capilla de S.M. el Emperador Carlos V al uso de la Casa de Borgoña. Estatutos que hasta agora se han guardado en la Capilla Imperial y se han de observar en la Real Capilla de S.M. conforme al uso de Borgoña (copied early 1560s). E-Mn MS 14.018/6 (Barbieri papers, possibly copied from original sixteenth-century document): ed. Barbieri papers 2, doc. 136, and Vander Straeten, La Musique aux Pays-Bas, viii, pp. 178-82 (from Barbieri papers)

\section{Philip II}

Estatuto de la Real Capilla, año 1562 y representaciones de los capellanes del Banco de Castillo al limosnero mayor de S.M. D. Luis Manrique, año de 1567 y 1569. Estatuto formado por el arzobispo de Santiago, D. Gaspar de Zúñiga, primer capellan mayor del Rey D. Felipe II, acerca del servicio que deben hacer los capellanes de su Real Capilla. Año de 1562. E-Mpa, Real Capilla, caja 66/6 (olim leg. 1, no. 9]; E-Mn MS 14.018/2 (Barbieri papers): ed. Barbieri papers 2, doc. $156[\mathrm{a}-\mathrm{c}]$

Advertencias de cómo se ha de ganar y repartir las distribuciones que Su Magestad Católica ha mandado poner en la capilla de cantores de su capilla real y capellanes de altar desde primero de o[c]tubre de 1584. E-Mpa Real Capilla, caja 76, olim Leg. 5, no. 1; E-Mn Ms 14.018/3 (Barbieri papers copied from 1791 document: Constitutiones de la Real Capilla para repartir las distribuciones . . 1584): ed. Barbieri papers 2, doc. 161 


\section{Bernadette Nelson}

Constituciones para el Real Colegio de Cantores de la Real Capilla del Rey nuestro señor. Hechas en tiempo de Felipe II. Visita 3 de octubre de 1672. E-Mpa, Administrativa, leg. 1116; E-Mpa Real Capilla, caja 105; E-Mn MS 14.017/9 (Barbieri papers copied from 1672 document): ed. Barbieri papers 2, doc. 157

Regimento da Capella Real [Lisboa] . . 1592 (drawn up in 1592 by Jorge de Ataide, first chaplain of the Portuguese royal chapel, and revised in 1608). P-Ln cod. 10981 (late copy); P-La cod. 50-V-26, fols. 1-11 ${ }^{v}$ (late copy); partial transcription of MS in Madrid: ed. Barbieri papers 2, doc. 176 (EMn MS 14018/12) 
Ritual and Ceremony in the Spanish Royal Chapel, c.1559-c.1561

\section{APPENDIX 3}

La Orden que se tiene en los Officios en la Capilla de su Magestad ${ }^{1}$

\section{[Sung masses on weekdays and Sundays]}

Cada dia se dize en la Capilla vna Missa Cantada sin Diacono, ni Subdiacono, los quales no sirven sinó en solos los dias de Domingos y fiestas de guardar, y otros dias que hay sermones como en la Quaresma y Adviento.

Tiene esta Orden para el Servicio de los Capellanes en las Missas Cantadas: que siempre el que dise la Missa una semana la que se sigue ha de hazer el Officio de Diacono, y luego la otra Tercera de Subdiacono, de manera que conforme al numero de los Capellanes de que les viene su turno, siempre comiença por la Missa, despues sirven de Evangelio, y Epistola.

El Subdiacono entre semana se halla a la Missa para cantar la Epistola, la qual (fol. $61^{v}$ ) se a costumbre siempre deçirse en atril con vn Missal pequeño teniendole el Subdiacono en las manos en el mismo lugar que se halla; quando acaba el Preste la Oracion, en aquel tiempo le dâ el Moço de Capilla el Missal en que ha de decir la Epistola, y acavada se le torna a tomar, y se sube al altar y passa el Missal con su Cojin, o atril a la parte del Evangelio.

El Evangelio canta el Diacono quando sirve en el altar, y al tiempo que se canta está el Sacerdote en pie arrimado al Altar el Rostro puesto hacia el Evangelio, y el Subdiacono vna grada en vajo.

Al Evangelio destas Missas Cantadas no acostumbran traer los pajes achas, sinó solamente en los dias de Domingo, o fiestas, quando se sirve la Missa con Diacono, y Subdiacono; (fol. 62) pero para la Consagracion siempre las sirven hasta que consume.

En los dias de Domingo o fiestas no principales sirven con dós achas al Evangelio, y a la Consagracion con quatro: quando son fiestas Principales, como Pascuas, y Apostoles, y dias de Nuestra Señora sirven quatro hachas al Evangelio, y seis a la Consagracion; tienesse por costumbre entrar los pajes con las achas al tiempo que comiençan los Sanctus.

Quando se acava el Evangelio van dos pajes con sus hachas acompañando a los que van a servir al Evangelio.

1 P-La 51-VI-37, fols. 61-79; a mid-seventeenth-century copy of the ceremonial drawn up in $c .1550$ by Aguirre, chaplain and receiver in the royal chapel; revised and updated in the early 1560 s. 


\section{Bernadette Nelson}

No se acostumbra en la Capilla a tomar Vendicion al Diacono del Prelado ni vendicir el insienso sinó en dias de fiestas principales que ay vendicion Episcopal.

El Asperges comiença el Preste vajo (fol. 62v) de las gradas del altar, y luego vuelve el isopo al Diacono el qual vá con el Prelado a servir el agua a Su Magestad y sinó ay Prelado el le dâ el agua, y vuelto a su puesto delante el altar le toma el Sancristan Mayor el Isopo y vá con vn Mozo de Capilla que lleva el agua, y comienza por el Legado o Nuncio si le ay, despues a los Prelados y a los Capellanes, Cantores, luego a los Embaxadores, y grandes, y a los demas pero quando los Embaxadores estan en vn banco con el Nuncio como es costumbre les dan el agua juntamente con el Nuncio. En este medio, el Sacerdote como acaban los Cantores los Versos del Asperges, se sube solo al Altar, y dize la Oracion, y acabada los Menistros suben tambien al Altar, y se ponen todos tres en medio hasta que comiencen el Gloria patri, y entonces le ponen la Casula que está en vn cuerno (fol. 63) del Altar a la parte del Evangelio, y comiença su Confession.

Estas Missas Cantadas de entre semana se comiençan en punto a las ocho desde Pascua de Ressurreccion hasta primera de Octubre, y dende en adelante, hasta Pascua, a las nueve; pero en los dias de Domingos, y fiestas principales, quando no sale Su Magestad vna hora mas tarde porque tengan lugar los que quisieren venir al officio.

Quando ay Pontifical, el Asperjes y la Oracion dize el Diacono, y el Prelado está asientado en su silla con los Menistros.

Sinó es Prelado el que dize la Missa no se acostumbra en la Capilla incensar la Oblacion.

En las Missas se sirve a su Ma- (fol. 63v) gestad, la pax, y el Evangelio y a las Visperas, a la Magnifica el incienso.

\section{[Low masses]}

\section{Missas Rezadas.}

Cada dia se dizen dos Missas rezadas en Palacio por la Emperatriz la vna, y la Otra del dia del Sancto que fuere segun la Regla del Calendario Viejo, y Romano, pero en los Jueves, Viernes, y Sabbados, quando el Sancto no tiene officio proprio dizen del Sancto Sacramento de la Cruz, y de Nuestra Señora.

\section{[Requiem mass]}

Acavando de dizir la Missa de Requien, dizen vn responso Ne recorderis, con solo la Oracion: Quaesumus Domine pro tua pietate. 
Ritual and Ceremony in the Spanish Royal Chapel, c.1559-c.1561

Y en la Missa no se acostumbra a dezir mas desta Oracion. (fol. 64)

\section{[Vespers]}

Visperas.

Dicense en la Capilla Visperas todos los Sabbados, y Domingos, y fiestas de Nuestra Señora, y Apostoles, y Quatro Doctores, y fiestas de guardar; y las Visperas destas fiestas, comiençalas el Semanero en medio del altar solo con la Capa, començando los Cantores el primer verso del Psalmo le quita la Capa el Mozo de Capilla, y la pone en el Altar a la parte del Evangelio y el se vá a sientar en la cavecera del Vanco de los Capellanes hasta la Capitula que vuelve a tomar la Capa para dezirla, y se está en pie con ella hasta que se acavan las Visperas; y no se está acompañando a los lados ningun Capellan.

En estas fiestas Principales a la Missa y Visperas hay Vendicion Episcopal del Prelado, y en estos dias se toma del Obispo la Vendicion del Evangelio, y del incienso, (fol. 64 ${ }^{\mathrm{v}}$ ) y el Subdiacono acavada la Epistola va a besar la Mano al Prelado, poniendose el Libro en las rodillas.

\section{[Compline]}

\section{Completas.}

Acavadas las Visperas siempre se dizen Completas avnque haya Visperas de Pontifical, y comienzalas en medio del Altar el Semanero como costumbra a las Visperas, y siempre con capa.

\section{[When to sing the Salve and motets]}

Salve, y motetes, quando.

Acavadas Completas siempre se dize vn motete en Canto de Organo, y los Sabbados Salve, quando son Visperas de fiestas principales, que quando lo son acavan las Completas con vn motete con sus versos y oracion; pero desde Pascua a la Ascencion en lugar de Salve (fol. 65) diçen Regina Caeli laetare, y responde el Organo, y al cavo la Oracion del tiempo.

\section{[Compline]}

Completas no se dizen en Visperas feriales quando se dizen acavada la Missa como en Quaresma; pero en este tiempo los Domingos se dizen Visperas y Completas a la tarde. 


\section{Bernadette Nelson}

\section{[Calendar of pontifical masses]}

\section{Missas de Pontifical.}

Hay en la Capilla ordinariamente Missas de Pontifical. Itten primer dia de Navidad.

Itten Dia de la Epiphania.

Itten a Veinte y vno de Mayo por el nascimiento de Su Alteza.

Itten dia de Pascua de Ressurreccion.

Itten dia de la Ascencion

Dia de Pascua de Pentecostes.

Dia de Corpus Christi.

Dia de Nuestra Señora de Agosto. (fol. 65v)

Dia de todos los Sanctos.

Dia de los Defuntos.

Dia de Sant Andres.

Solo se inciensa a El Rey y no a otro, avnque este prezente el Princepe.

Otro dia de Sant Andres, y de Diffuntos no ay paz ni Evangelio solo siempre que hay Missa de Pontificial se dizen primeras Visperas de Pontifical, dize el Responso acabada la Missa, y no se dize De Profundis, sinó en el Capitulo del Tuson.

El Diacono y subdiacono que son semaneros se visten con el Prelado, los Assistentes y otros Menistros, no estando el Capellan Mayor presente los nombra el Receptor, danse Capas a los dos Assistentes, y al vaculo, y a la mitra.

Para todo se vea el Pontifical, y se siga tratandolo el Limosnero Mayor (fol. 66) con el Sancristan Mayor, y Maestro de Capilla.

\section{[Vigils for commemorations]}

Quando se dicen Visperas, y Vigilias de Pontifical como el dia de todos los Sanctos, y Sant Andres se tiene esta orden: dichas las Visperas del dia si Su Magestad no está presente aguardan a que salga, y dizen Visperas y Vigilias de difuntos y otro [dia] la Missa, y acavada la Missa se dize vn Responso Cantado.

No hay hachas quando hay velas al responso, y al alzar llevanse quatro hachas los pajes.

En estas Vigilias de Diffuntos siempre se dizen Laudes avnque no se diga mas de vn Nocturno, como acontece muchas vezes mandar Su Magestad que no se diga mas que vn Nocturno.

Dize el Semanero la Antiphona de las (fol. 66 $6^{v}$ ) Visperas, con capa en medio del altar, y quitasela luego hasta que buelva a decir la antiphona del Magnifica: y la Magnifica y Oracion todo lo dize con capa y en la Vigilia los Pater Nostres antes de empezar las Liciones dize con capa 
paso entono, y canta Et ne nos, y dexa la capa a la postrera Liccion dize en el Altar con su capa, y la dexa en acavandola, y nó la toma mas hasta que buelva a dezir la antiphona del Benedictus; y el Benedictus y Oracion, y no se dize Responso si no hay Cuerpo presente hasta en fin de la Missa de otro dia.

\section{[Obsequies for the death of kings, princes or infantes]}

\section{Obsequias por Muerte de Reyes, o Princepes, o Infantes.}

Quando se hazen honrras por Muerte de Reyes Princepes ó Infantes dize las Visperas, y Vigilias vn Prelado, y otro dia se dizen tres Missas de Pontifical haviendo Obispos (fol. 67) ó Abbades que las digan: la primera del Spirito Sancto, la segunda de Nuestra Señora, la tercera de Diffuntos a la qual sale Su Magestad, porque las otras dos se dizen antes que salga.

\section{[Time of Matins on Christmas night]}

\section{Maytines.}

Dizense Maytines la Noche de Navidad suelense comenzar a las diez.

\section{[Corpus Christi and Octave]}

Dia de Corpus Christi con todo su Octavario, y comiençan en amaneciendo, y dizen todas las horas alternando los Psalmos sin que los Capellanes le ayuden.

La Orden que se tiene en esta fiesta de Corpus Christi es que el Miercoles de la Vigilia el que dize la Missa Cantada consagra vna forma de mas de la que ha de consumir y acavada la Missa la ponen en su Custodia, y cantando los Cantores Tantum ergo (fol. 67v) Sacramentum, vendiciendo el Pueblo con la Custodia, al tiempo que llegan aquel passo Sit et beneditio, con muchas achas, y ensienso y campanilla le llevan al lugar que está aparejado para ponerle.

Siempre que el Sacerdote le toma ó le dexa le insiensa tres vezes.

Despues a las Visperas, venido Su Magestad, le sacan como le llevaron, y acavadas las Visperas le buelven con la misma solemnidad, hasta otro dia a la mañana, que le sacan a los Maytines; y lo mismo hazen entre semana el Viernes despues de la Octava le consume el Sacerdote que dize la Missa Cantada. 


\section{Bernadette Nelson}

\section{[Processions]}

\section{Processiones.}

Dia de Ramos.

Dia de Corpus Christi.

Dia de la Purificacion. (fol. 68)

En las processiones se tiene esta orden: Su Magestad vá detras del Prelado que haze el Officio con los Embaxadores, y Princepes, y Embaxadores y Grandes; delante del Prelado y de los Menistros que le assisten, van los Obispos, y Capellanes, y los Cantores; luego los Cavalleros, y los demas todo en orden, el Sancristan Mayor y el Rec[ep]tor tienen cargo de Ordenallos.

Quando se lleva el Sacramento, lleva Su Magestad vna hacha blanca delante, y tambien los Princepes, y Señores que se hallan en la procession.

\section{[Episcopal blessings: Palms and Candles]}

Benediciones Episcopales de Ramos, y Candelas.

Dia de la Purificacion, las Candelas.

Dia de Ramos, los Ramos, y no dize la Missa estos dos dias el Prelado. (fol. 68v)

\section{[Offerings]}

Primer dia de Navidad.

\section{Offrendas.}

Dia de la Circuncizion.

Dia de la Purificacion.

Dia de la Epiphania. Este dia offrece Su Magestad tres copas de plata doradas con sus sobrecopas de valor de treinta ducados cada vna; en la primera offrece vn ducado y en la segunda encienso, y en la tercera Mirra. Dia de Sancto Mathia por su nascimento offrece Su Magestad tantos ducados quantos annos cumple, y más el anno en que entra; esto mismo haze El Rey Nuestro Señor a viente y vno del Mayo.

Primer dia de Pascua de Resurreccion.

Dia de la Ascencion.

Primer dia de Pentecostes.

Dia de Corpus Christi.

Dia de Nuestra Señora de Agosto.

Dia de Todos Sanctos.

Dia de los finados, con vn escudo en vna vela (fol. 69) encendida.

Dia de San Miguel quando sale con habito de la Orden de Francia no hay Pontifical.

Dia de Sant Andres con todos los Cavalleros de la Orden del Tuson.

Otro dia de Sant Andres con vna vela encendida offrece el escudo hincado en la vela. 
Ritual and Ceremony in the Spanish Royal Chapel, c.1559-c.1561

\section{[Adoration of the Cross on Good Friday and on the feast of the Invention of the Cross on 3 May]}

Adoracion de la Cruz en el Viernes Sancto.

En el Viernes Sancto se offrece a la adoracion de la Cruz, guardasse esta orden: acavado el Sacerdote, que haze el Officio de adorar con el Diacono, y Subdiacono, vá a adorar el Legado Nuncio Apostolico si está en la Capilla, despues los Obispos, los Capellanes, los Cantores, y officiales Clerigos de la Capilla; acavando estos sale Su Magestad, luego los Embaxadores (fol. 69v) los grandes, y los Cavalleros.

Porque no impidan al officio, acavando de adorar los Cavalleros, apartan la Cruz con el Coxin y estrado a vn lado, y acavado el Officio van addorar todos los que quieren.

Siempre que hay palo de la vera Cruz en Palacio le ponen este dia para la adoracion.

En la fiesta de la Cruz que se zelebra a tres de Mayo sacan al altar la Cruz con el vero palo, y acavada la Missa el Sacerdote o Prelado, si le hay con su Estola la dá a besar a Su Magestad delante del Altar; este dia no acostumbra Su Magestad a oir Missa Cantada.

\section{[Calendar of days for sermons]}

Sermones ordinarios.

En la Septuagessima, sexagessima, y quinquagessima. (fol. 70)

En la quaresma cada dia haviendo copia de Predicadores.

En el Adviento cada dia haviendo Predicadores.

Segundo dia de Pascua de Ressurreccion.

Dia de la Annunciacion de Nuestra Señora.

La Domin[ic]a infra Octava de la Ascencion.

Segundo dia de Pentecostes.

Domingo de la Trinidad.

La Dominica infra Octava Corporis Christi.

El dia de Santiago.

Dia de Sant Andres.

En Flandes, en Hespaña, primero Domingo de Adviento.

\section{[Holy Week: Tenebrae]}

\section{Tenieblas.}

Comienzan las Tenieblas el Miercoles de la Semana Sancta a la hora que Su (fol. 70v) Magestad sale.

\section{[Lamentations]}

Las Lamentaciones se dizen ordinariamente con biolones y quatro vozes: Tiple, Contralto, Tenor, y Contravajo; y las Lecciones los Capellanes. 


\section{Bernadette Nelson}

\section{[Mandatum on Maundy Thursday and Passion on Good Friday]}

Mandato, y passion.

El Mandato se predica ordinariamente en la Missa a la hora de los otros sermones.

La passion el viernes a las siete, y acavada se comienza el Officio.

En la Capilla de Su Magestad, Jueves, Viernes, y Sabbado Sancto no se acostumbra hazer el Officio Prelado.

\section{[Matins on Vigils for the dead]}

Quando hay Maytines ó Vigilias de difuntos, la primera leccion suele dezir vn niño de los Cantores, y las demás los Capellanes (fol. 71) de este arte, y las tres postreras, dizen el Semanero, Subdiacono, y el Diacono, y el que haze el Officio.

[Vigils and mass for the Empress on 1 May, and for the Emperor on 21 September]

Cabo de Anno por la Emperatriz Nuestra Senora.

Cabo de anno se haze por la Emperatriz Nuestra Señora cada anno en la Capilla dizense Visperas, y Vigilias.

Primer dia de Mayo despues de las Visperas de San Philippe y Santiago, y otro dia la Missa, las Vigilias se dizen con tres Nocturnos y Laudes.

En la Missa offrece Su Magestad vn ducado, y vna vela de cera en que vá hincado [vn escudo] ${ }^{2}$ acavada la Missa se dize vn Responso Cantado, lo mismo por el Emperador, a veinte y vno de Septiembre. (fol. $71^{v}$ )

\section{[Order for preparing torches in the chapel]}

$$
\text { La Orden de servir las hachas en la Capilla. }
$$

A todas las Missas Cantadas se hallan todos los pajes de Su Magestad, y sirven siempre las hachas de las quales tiene Cargo el furriel de la Capilla de tenellas encendidas, al punto que son necessarias; y despues del Servicio tomallas a los pajes y tambien tiene Cargo de hazer este officio vn mozo de la zereria.

Al Evangelio de las Missas Cantadas entre semana no se sirven hachas sinó es dia que se haga el officio con Diacono y Subdiacono. 
Ritual and Geremony in the Spanish Royal Chapel, c.1559-c.1561

\title{
[Officers of the chapel]
}

\author{
Officiales de la Capilla \\ [Capellan Mayor]
}

Capellan Mayor siempre que está en la Capilla haçe el officio, sinó lo (fol. 72) quiere por comedimiento encomendar a otro Prelado.

El Capellan Mayor quando está auzente suele nombrar por su substituto vn Prelado de los que residen en la Corte a quien dá sus vezes.

El Capellan Mayor nombra vn Juez en la Capilla de los mesmos Capellanes el qual conoce de todas sus cauzas y differencias sin que otro Juez intervenga entre ellas.

El Capellan Mayor manda y veda en la Capilla lo que le pareze que conviene al buen govierno y administracion de ella.

El Capellan Mayor o su Lugar Teniente en su auzencia acostumbra ajuntar Capilla en sus possadas adonde le parece en el mez vna vez, y más (fol. $72^{v}$ ) se se offrece necessidad.

El Capellan mayor, lleva destribuiciones por dós Capellanes.

\section{Limosnero Mayor.}

El Limosnero Mayor demás de hazer su officio de la Limosna assiste a todos los officios de la Capilla, y quando no ay Prelado ó Diacono, el sirve el Evangelio, y la paz.

El Limosnero Mayor en la Capilla de Su Magestad, govierna los Cantores a quien obedecen como a Capellan Mayor, y lo mismo los officiales de ella.

El Limosnero Mayor tiene cuenta con saber de Su Magestad a la hora, el como y quando quiere los Officios. (fol. 73)

Hay de contino en la Capilla de Su Magestad, segundo Limosnero, el qual en auzencia del Limosnero Mayor haze el Officio.

\section{Sacristan Mayor.}

El Sacristan Mayor probee todo lo que tocca al adrezo, y servicio del Altar.

El Sacristan Mayor acompaña al Prelado Limosnero, o Diacono, o qualquiera otro que vsa de alguna ceremonia en la Capilla. Y le toca el hazer la salva del Evangelio, y paz ansy mismo acompaña a los Predicadores allevarlos, y bolverlos del pulpito, y tambien a los Capellanes y Cantores que salen a dezir Licciones, y buelve con ellos a sus assientos y lugares. (fol. $73^{v}$ ) 
Sumilleres del Oratorio.

Los Sumilleres del Oratorio son dos, y sirven a semanas, su Officio es registrar el Missal, y las horas ó a qualquiera otro Libro en que $\mathrm{Su}$ Magestad haya de rezar; el Sumiller assiste junto a la Cortina, y quando Su Magestad quiere entrar la abre, y despues la cierra, tiene cuenta con lo que Su Magestad mande.

Al Sumiller tocca advertir a los mozos del Oratorio que le tengan limpiamente aderezado.

Quando faltan los Limosneros, el sumiller mas antiguo haze el Officio.

\section{Receptor.}

El Receptor de la Capilla recive y reparte todas las destribuiciones que se offrecen (fol. 74) como de entradas, offrendas, legitimaciones o qualquier otra cosa que se haya de destribuhir.

El Receptor en auzencia del Capellan Mayor, o su Lugar teniente encomienda el Prelado y Capellanes que han de salir a hazer el officio.

Suele acompañar el Receptor en los Domingos, y fiestas a los Prelados que van a servir el Evangelio, y la paz a los prestes.

El Receptor tiene Cargo de encomendar los Sermones, y semanas de Missas y otros Officios de la Capilla.

El Receptor tiene Cargo de avisar los Capellanes; quando hay algun Officio extraordinario en la Capilla lleva el Receptor destribuiciones por dós Capellanes. (fol. 74v)

\section{Capellanes.}

Los Capellanes reconozen por su Superior al Capellan Mayor ó a su Lugar teniente, y por Juez al que constituyere el Capellan Mayor.

Los Capellanes han de tener cuenta con no faltar en sus semanas en los Officios que les toca.

Los Capellanes sino fuere con causa legitima no se pueden escusar de tomar la semana que les tocare, y les fuere encomendada por el Receptor.

Los Capellanes han de hallarse en la Capilla especialmente Domingos y fiestas.

\section{Maestro de Capilla y Cantores.}

El Maestro de Capilla y Cantores han (fol. 75) de tener quenta con no faltar a las horas de los Officios, y quando algun Cantor falta de nó venir a las horas, el Maestro de Capilla le reprehenda y quando es pertinaz, dizelo al Limosnero Mayor para que le corrija, y dicen todas las horas los Cantores. 
Ritual and Ceremony in the Spanish Royal Chapel, c.1559-c.1561

\section{Mozos de Capilla}

Hay de ordinario quatro mozos que sirven: dós tienen cargo de servir en las Missas Cantadas, y dós en las rezadas.

Los de las Missas Cantadas tiene cargo de tener adereçado el Altar a su hora que no haya falta y ayudar a las Missas.

\section{Mozos de Oratorio.}

Los otros dos tienen cargo de ayudar a las (fol. 75v) Missas rezadas, y aderezar el Citial, y Cortina de manera que estê limpio todo, y aparejado para quando Su Alteza saliere. Estos han de cojer acavada la Missa rezada el adrezo del Altar, y metello en sus Cofres. Porque se presupone que los de las Missas Cantadas ya han hecho su officio, y recogido lo que les toca.

\section{Furrier de la Capilla.}

Hay Furrier de la Capilla el qual tiene Cargo de hazer el aposento de los Capellanes, y Cantores y officiales de la Capilla.

Este tiene Cargo de hallarse a todos los Officios, y al tiempo que quieren comenzar tañer la Campanilla de la Capilla, en los corredores, ó donde se oyga de los que andan en el patio, para que los Capellanes, y Cantores que estan en el patio acudan al officio. Más tiene Cargo de los (fol. 76) assientos de los Capellanes, y Cantores, y quando falta algun banco haze que lo traygan de la Furrieria.

\section{Organista.}

El Organista, y el que entona tiene de hallarse a la hora de los officios quando es necessario que se taña el Organo, quando haçen falta, el Limosnero los reprehende.

\section{[Admission of chaplains and cantors to the chapel, and how to receive distributions]}

\section{Entradas de Capellanes.}

Todos los Capellanes de Su Magestad primero que tomen sobrepellis ó le admitan en la Capilla, quando entran de nuevo han de hazer la solemnidad del juramento ante el Capellan Mayor, y el Receptor, y pagan al Receptor tres mil reis de entrada para toda la Capilla. (fol. $76^{v}$ )

En auzencia del Capellan Mayor o su Lugar teniente hazen la solemnidad del juramento ante dós Capellanes los mas antiguos, y el Receptor, el qual dâ fée a las espaldas de la Zedula de esto.

Todos los Cantores y officiales de la Capilla, se quisieren ganar destribuiciones han de pagar la entrada como vn Capellan excepto el Capellan Mayor, y los mozos y los niños. 


\section{Bernadette Nelson}

Los quatro mozos de Capilla llevan dós destribuciones. Los niños suelen ser ordinariamente doze, y todos que hayan menos ó mas ganan por dós Capellanes, como los mozos de Capilla.

\section{[Final statement]}

Esto se acostumbra al prezente, y se guarda en la Capilla de Su Magestad, pero ha se variado en alguna manera con los tiempos, y lugares por dó Su Magestad anda, y ansy vemos que en España (fol. 77) con la Capilla Real hay algunas ceremonias diversas.

[Addendum]

Esta rellacion me dió Aguirre, Capellan de Su Magestad, y Receptor de su Capilla.

El Contralor tiene otra relacion en Frances, que le imbió el Limosnero Mayor, de la manera que se sirve la Capilla al vzo de Borgoña.

\section{[Calendar of days for sermons]}

Ver Capitulo zerca de los sermones que ha de haver en la Capilla de Su Magestad, si se guarda lo que en la de su padre.

Yten que los Domingos de la Septuagessima, o Sexagessima, o Quinquagessima, o Quadragessima, el dia de la Ceniza, los Domingos, Viernes, y fiestas de Quaresma, y del Adviento, (fol. 77v) las fiestas de Nuestro Señor, y las de Nuestra Señora, los Lunes despues de Pascua y de Pentecostes, los dias de Sant Andres, Sam Pedro en Junio, Santiago, dias de todos los Santos, y de los finados habra Sermon en nuestra Capilla, si nó mandamos otra cosa.

Su Magestad, dia de todos los Santos y de difuntos, quiere Pontifical y no Sermon.

\section{[Feast of the Purification when the King goes to a monastery]}

Dia de la Purificacion, acostumbra Su Magestad hir a vn Monasterio; a la Vendicion de las Candelas, está vn flaire del mismo Monasterio, i a la Vendicion de las Candelas con la Cruz grande con su manga y dos acolitos con sus velas acavada la Vendicion vá el flaire con la Cruz, y los dos acolitos delante y todo el Convento le sigue; y luego los Cantores de Su Magestad, y luego los Officiales, y Capellanes de Su Magestad, y luego obispos, y despues (fol. 78) los mazeros, y Mayordomos, y luego el Prelado que dixo la Vendicion de las Candelas con sus assistentes, y Menistros, [y] luego Su Magestad, y vn poco mas atras el Nuncio y Embaxadores y Grandes, y los Cavalleros van adelante ó a los lados donde no estorben a la Gapilla.

La Vela se le ha de dar a Su Magestad, quando ya acaban de hir sus Capellanes a la procession, y entonces acaba el Obispo a dezir la postrera Oracion. 
Acavada la procession, va se el Prelado al Altar Mayor con sus assistentes y Menistros, y hecha la vendicion ordenaria, y respondenle los Cantores.

\section{[Sermons during Lent]}

En passando la Dominica de Septuagessima se trate con Su Magestad de la Orden que manda se tenga con (fol. $78^{v}$ ) todos los Sermones de la Quaresma para avisar a los Predicadores.

\section{[Distribution of ashes on Ash Wednesday]}

Miercoles de Zeniça vn Prelado dá siempre a Su Magestad la zeniza assi como anda con sola la roquete.

Por la mañana luego se dize una Missa Rezada, y se vendize la Zeniza, y otras vezes luego se vendize la zeniza, luego se dá a todos los que la quieren tomar, y despues antes que Su Magestad salga la toma toda la Capilla.

En saliendo Su Magestad se vá derecho a tomar la zeniza antes que entre en las Cortinas, despues la toman los Grandes, y Mayordomos, y Cavalleros de la Camara y nó mas, y luego se prosigue el Officio, y vn Capellan se pone a dar la zeniza a los otros Cavalleros porque no se impida el Officio a vn lado del Altar; y acavada la Missa, otro (fol. 79) Capellan dá la zeniza a todos los que quieren tomarla.

Yendosse Su Magestad fuera se junta toda la Capilla en el aposento de la Reyna y lo mesmo yendosse la Reyna en el aposento de El Rey.

Al Rey y Reyna, Princepe y Princeza se sirve paz y Evangelio, no se sirve nada a Don Juan de Austria, avnque le ponen sola una silla rasa pequeña dentro de la Cortina sin almohada.

\section{[Vespers during Lent]}

En las Visperas que se dizen en Quaresma antes de comer no se canta nunca motete, comienzanse las Visperas por el Diacono en alzandosse el Caliz. 


\title{
Bernadette Nelson
}

\author{
APPENDIX 4 \\ Estatutos de la Capilla del Emperador Carlos quinto al vzo de la Caza de \\ Borgoña ${ }^{1}$
}

La Orden que mandamos que se tenga en Nuestra Capilla es la siguiente.

[1] Mandamos y ordenamos que todos los Cappellanes, Cantores y Officiales de Nuestra Capilla de Nuestros Estados de Flandes tengan por superior, y le tengan reverencia al nuestro Limosnero Mayor, obedeciendole en todo lo que el mandare, que fuere por el servicio de la dicha Capilla, sob pena, que quien no lo hiziere les pueden castigar por suspenciones de sus officios, rayar sus gajes o otra correccion que le pareciere porque en este le havemos dado, y damos la authoridad y poder que a el conviene.

[2] Mandamos que de aqui adelante el Officio Divino se celebre en Nuestra Capilla Conforme al Vzo, y Costumbre de la Iglesia Romana, tanto (fol. 80) a Maytines, Missas, Visperas, guardando las Ceremonias y Costumbres Romanas.

[3] Yten que cada dia la Missa se cante por nuestros Cantores, en la Capilla en Palacio, a las nueve horas encomenzando desde el dia de Santo Remis hasta el dia de Pascua de Ressurreccion, y desde el dicho dia de Pascua se dirá a las ocho hasta el dia de San Remís, y las Visperas en los dias que aqui seran nombrados, y entiendesse quando Nos estuvieremos presente, porque teniendo algunos negocios habran de esperar hasta la hora que havremos mandado a nuestro dicho Limosnero; y quando fuere que en Nuestro Palacio no obiere Capilla, ni lugar donde el officio no se pudiere celebrar, mandamos que se haga en la mas cercana Iglesia o Capilla de nuestro Palacio, conforme a lo que pareciere a nuestro dicho Limosnero, que en todos los dias de fiestas grandes y pequeñas y Vigilias dellas que se guardan en el pueblo donde estubieremos se diran Visperas y Completas conforme a la fiesta, y segun las Ceremonias, y Vso Romano. (fol. 80v)

[4] Yten que todos los Capellanes, Cantores, y Officiales de Nuestra dicha Capilla celebrando el Officio Divino seran obligados ser vestidos ropas largos bonetes, y habitos de Clerigos, la barba y corona rapada sob pena de ser rayado de sus gajes del dia que hicere falta.

[5] Yten q(ue) los Capellanes Cantores, y Officiales sean obligados

P-La 51-VI-37, fols. 79-84, a mid-seventeenth-century copy of a document of $c .1518$. 
entrando en la dicha Capilla ponerse en rodillas, y hazer Oracion.

[6] Yten que los dichos Capellanes Cantores y Officiales haciendo el Officio Divino estaran en pie q(uan)do se cantare el Introito de la Missa, [Kyrie], Gloria in excelsis Deo, y el Evangelio, el Credo, Sanctus, Pater Noster, y Agnus Dei, y ansi mismo quando se encomienzan las Visperas, Completas, Magnificat, Nunc Dimitis, y las Oraciones teniendo las cavezas descubiertas, y en el Advento y Quaresma a las preces, y Oraciones se pondran de rodillas como es de costumbre.

[7] Yten zelebrando el Officio Divino se guardaran de hablar ni reir ni hazer cosas desconvenientes (fol. 81) para quitar la devoción a los assistentes sob pena de ser rayado de sus gajes.

[8] Yten que Nuestro dicho Limosnero mayor mandará venir a su posada, cada Viernes si no tienen occupacion legitima a todos los Capellanes, Cantores y officiales de Nuestra dicha Capilla donde terâ Capitulo, y corregirâ a los que habran errado para que se emienden, y se la pena del que huviere errado fuere pecuniaria el dicho Nuestro Limosnero la mandará executar, y recevirlo en que fuere el delinquente condemnado para que despues se reparta entre todos los otros.

[9] Yten si alguno de los dichos Capellanes, Cantores y officiales de la dicha Nuestra Capilla se auzentaren de la corte sin su licenzia el dicho Limosnero avisará por el furrier de la Capilla a los Mayordomos y los de Nuestro Bureau para que el dicho tal sea rayado de sus gajes durante su auzencia.

[10] Yten que los Domingos de la Septuagessima, Sexagessima, Quinquagessima, Quadragessima (fol. 81 $1^{v}$ ) el dia de la zeniza, los Domingos, Viernes y fiestas de Quaresma, y del Adviento, las fiestas de Nuestro Señor, y las de Nuestra Señora, los Lunes despues de Pascua, y Pentecostes, los dias de Sant Andres, San Pedro en Junio, Santiago, Dias de todos los Sanctos, [y] de los finados abrá sermon en Nuestra dicha Capilla sinó mandamos otra cosa.

[11] Yten que el Capellan Semanero se estará delante del Altar vestido de vna sobrepelliz quando huviere de encomenzar los Maytines, Visperas, Completas, o Vigilias, assim mesmo el que huviere de cantar la Epistola estarâ em pie de la parte del Altar que conviene, y las Lecciones, que se han de cantar a los Maytines se cantaran en vn facistol delante del Altar, y el o ellos, que los huviere de cantar sera vestido de vna sobrepelliz.

[12] Yten quando el Maestro de la Capilla estando en ella mandare cantar vn duo (fol. 82) o trio, a algun Cantor seran obligados de hazerlo sob pena de haver la correpcion que mereciere.

[13] Yten que de aqui adelante las Aleluyas se cantaran cada dia como en las fiestas grandes, y mandarâ el Maestro de Capilla cantarla[s] a los 


\section{Bernadette Nelson}

Cantores a cada vno su dia, y que los dichos Cantores se pongan donde han de estar sin se mesclar los vnos con los otros, y han de obedezer al dicho Maestro en lo que tocca al cantar sob pena como arriva esta dicho.

[14] Yten mandamos que de aqui adellante el dicho Maestro acompañe los Cantorcicos desde su possada a la Capilla, y desde allá a su possada, y se tiene occupacion legitima, comette a alguna persona que les acompañe, y les dê tiempo desde la vna hasta las tres despues de medio dia.

Y las Visperas de fiestas desde la vna hasta las dos para estudiaren gramatica y no permita a los dichos Cantorcicos hir cantar (fol. 82v) de casa en casa sob pena de perder su Officio.

[15] Yten que el dicho Maestro tenga cuidado de los dichos muchachos que esten limpiamente y bien tratados, y les haga comer y bever acostar y llevantar a las horas acostumbradas, y que conviene para la salud de ellos.

[16] Yten que el Maestro que les ha de enseñar Latin será obligado a hir cada dia vna vez a darles leccion en la posada del Maestro de Capilla.

[17] Yten mandamos que todos los sobredichos Capellanes, Cantores, y officiales de Nuestra dicha Capilla sean vestidos vna ves al año de paño negro ó chamelote para ropas y sayos de terciopelo, y mandaran hazer sus vestidos todos de vna forma y los Cantorcicos seran vestidos como han sido en tiempos passados. (fol. 83)

[18] Yten mandamos que todos los que recevieremos de aqui adelante, de qualquier calidad que sean las personas para servicio de Nuestra Capilla, entiendesse de Nuestros Estados de Flandes y habran de jurar en manos de Nuestro dicho Limosnero Mayor.

[19] Yten mandamos que el Maestro de Capilla, si mandare a algunos muchachos sacar, y llevar algun libro de canto o musica fuera de la Capilla, y si lo hicieren, que los Mozos de Capilla avisen luego al Limosnero para remediarlo sob pena de ser castigado.

[20] Yten mandamos que de aqui adelante ninguno mande tañer a Missa ó a Visperas sin primero avisar al dicho Limosnero si estubiere presente ó en su auzencia al Maestro de Capilla, y que el officio se haga al vso Romano, si de otra manera, por algun buen respeto no se mandase (fol. $83^{v}$ ) otra cosa por el dicho Maestro, o dicho Limosnero.

[21] Yten mandamos que el dicho Maestro se esté en el Coro detras de los muchachos, y que todo lo que huviere menester para la necessidad de ellos lo habrá de comunicar, y dar a entender al dicho Limosnero para que quando quisiere dar sus partidas que el dicho Limosnero abrá de firmar se acuerda de ellas. 
Ritual and Ceremony in the Spanish Royal Chapel, c.1559-c.1561

[22] Yten mandamos que el dicho Maestro tenga cuidado de ver y ordenar los libros de musica, y lo que se ha de cantar en el Officio Divino, y que los Cantores le obedescan sob pena de ser castigados.

[23] Y mandamos que todo lo sobredicho se declare publicamente a todos los de la Nuestra dicha Capilla, para que despues no digan no lo havian entendido, y mandamos al dicho Limosnero que haga que (fol. 84) todos los susodichos prometan de guardar y cumplir nuestros dichos mandatos.

[24] Yten mandamos que el Furrier de la dicha Capilla, este en la dicha Capilla antes de la hora del Officio Divino, para ver si los dichos Capellanes, Cantores, y officiales hazen lo que les está mandado a la entrada de la dicha Capilla, y si estando en el servicio Divino hicieren alguna derision o falta será obligado a avisar dello al dicho Limosnero. 


\section{APPENDIX 5}

Musicians and Other Members of the Royal Chapels, 1556-December $1562^{1}$

\section{FLEMISH CHAPEL ${ }^{2}$}

\begin{tabular}{|c|c|c|c|c|c|c|c|}
\hline Name & Office & $\begin{array}{l}\text { Year } \\
1556^{3} \\
\text { (June) }\end{array}$ & $\begin{array}{r}c .1557-8^{4} 1558^{5} \\
\text { (May- } \\
\text { Dec.) }\end{array}$ & $\begin{array}{l}1559^{6} \\
\text { (before } \\
\text { Apr.) }\end{array}$ & $\begin{array}{l}1559^{7} \\
\text { (May- } \\
\text { Aug.) }\end{array}$ & $\begin{array}{l}1562^{8} \\
\text { (May- } \\
\text { Aug.) }\end{array}$ & $\begin{array}{l}1562^{9} \\
\text { (Sept.- } \\
\text { Dec.) }\end{array}$ \\
\hline
\end{tabular}

\section{Capilla}

Odart de Bersaques

Valeran Haugonart

Pedro Paçeco

François de Rosimbos

Maximilian de Bergues

M. de Latour (La Torre)

Nicolas Payen (d. 1559)

Pierre de Manchicourt

Flemish chaplains

Jacques Pannier

Pierre Lorier

Odart Eyze

Noël Rou (de Roy)
Limosnero mayor

Secundo limosnero

Gran Limosnero mayor

Sumiller de oratorio

Sumiller de oratorio

Sumiller de oratorio

Maestro de capilla $\mathrm{x}$

Maestro de capilla

(Missas cantatas)

(Missas cantatas)

(Missas cantatas)

(Missas cantatas)

$\begin{array}{lllll}\mathbf{x} & (\mathbf{x}) & {[\mathrm{x}]} & (\mathrm{x}) & ? \\ \mathbf{x} & \mathbf{x} & {[\mathbf{x}]} & \mathbf{x} & ? \\ & & & & \\ \mathbf{x} & \mathbf{x} & \mathbf{x} & \mathbf{x} & ? \\ \mathbf{x} & \mathbf{x} & \mathbf{x} & \mathbf{x} & ?\end{array}$

$\mathbf{x}$

$\mathbf{x}$

$\mathbf{x}$

$\mathbf{x}$

x

(8) (7-8) (6-9) (7-10) (8-9) (10)

$\mathrm{x} \quad \mathrm{x} \quad[\mathrm{x}] \quad \mathrm{x}$

$\begin{array}{llll}\mathrm{x} & \mathrm{x} & \mathrm{x}\end{array}$

$\mathrm{X}$
$\mathbf{X}$

$\mathbf{X}$ $\mathbf{x}$
$\mathbf{x}$
$\mathrm{x}$

$\mathbf{X}$

$\mathbf{x}$ 


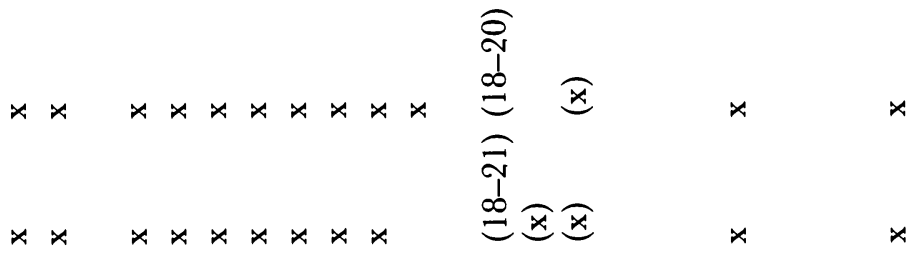

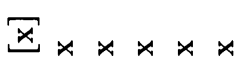

$$
\begin{aligned}
& * \times \widehat{x} \times \bar{x} \bar{x}
\end{aligned}
$$

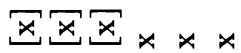

$$
\begin{aligned}
& x \times \widehat{\otimes} x \\
& \stackrel{\partial}{\Xi} x x x x x x x
\end{aligned}
$$

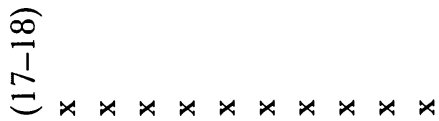

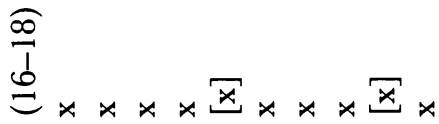

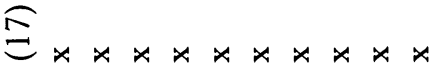

$$
\begin{aligned}
& x \times x \times
\end{aligned}
$$

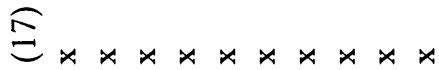

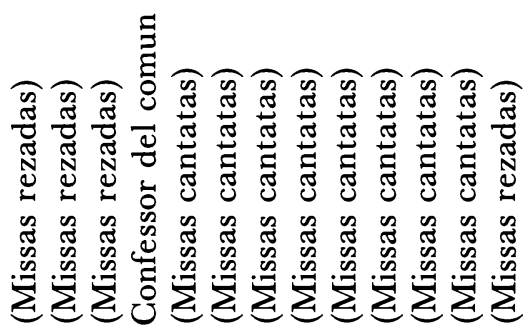

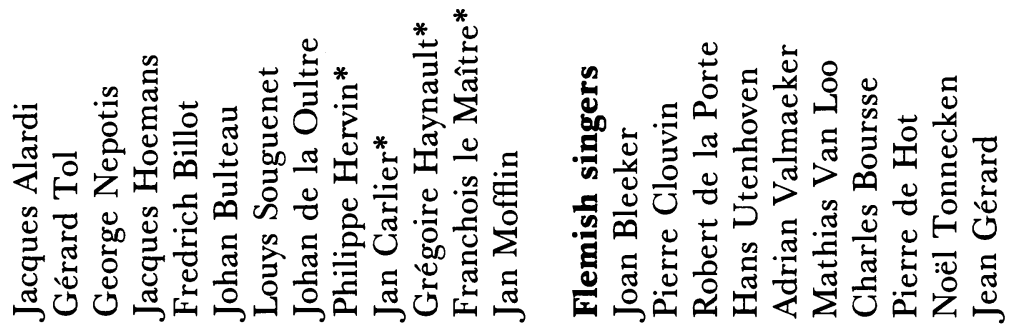




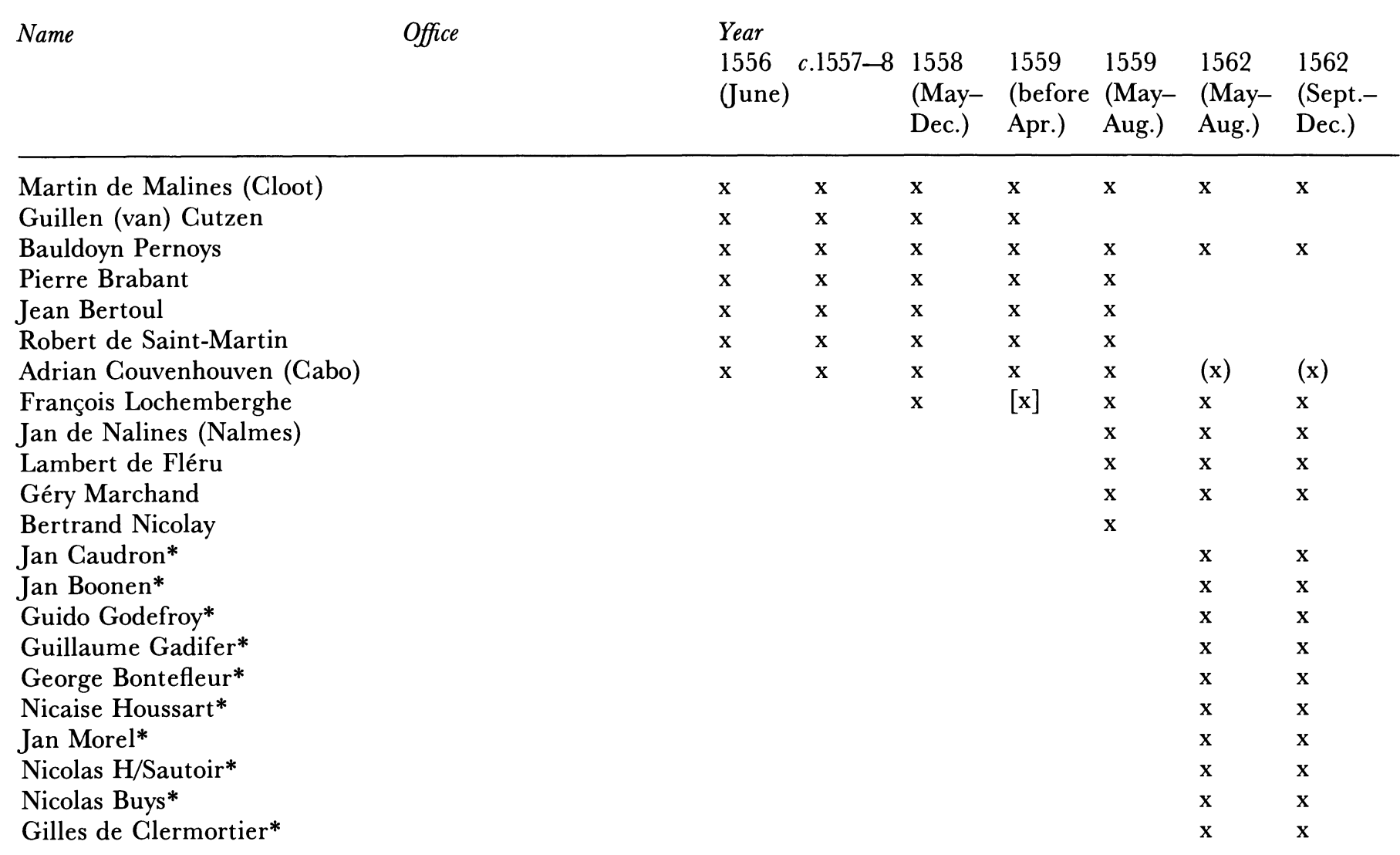



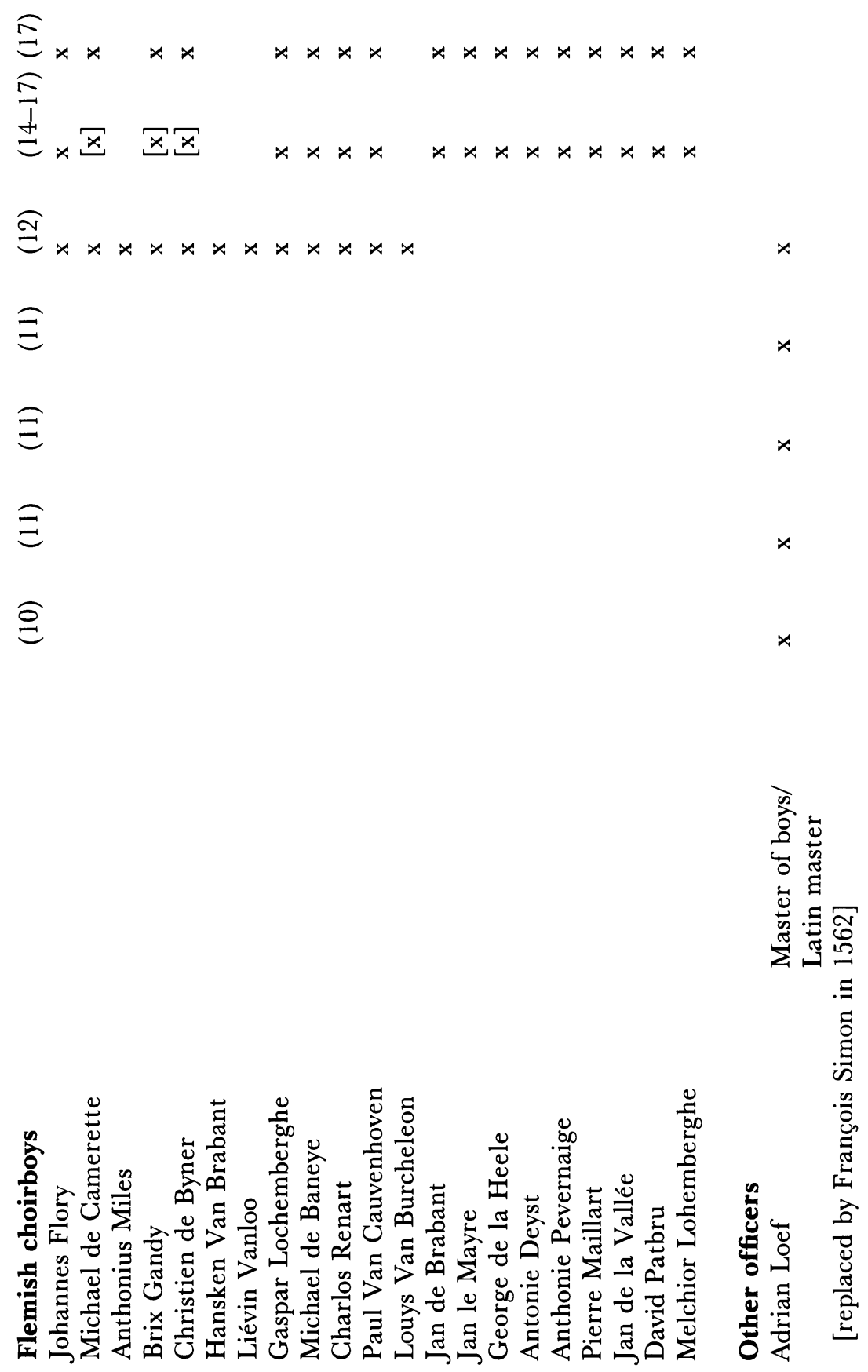


\begin{tabular}{|c|c|c|c|c|c|c|c|c|}
\hline Name & Office & $\begin{array}{l}\text { Year } \\
1556 \\
\text { (June) }\end{array}$ & $c .1557-8$ & $\begin{array}{l}1558 \\
\text { (May- } \\
\text { Dec.) }\end{array}$ & $\begin{array}{l}1559 \\
\text { (before } \\
\text { Apr.) }\end{array}$ & $\begin{array}{l}1559 \\
\text { (May- } \\
\text { Aug.) }\end{array}$ & $\begin{array}{l}1562 \\
\text { (May- } \\
\text { Aug.) }\end{array}$ & $\begin{array}{l}1562 \\
\text { (Sept.- } \\
\text { Dec.) }\end{array}$ \\
\hline Michel Boch & Organist & $\mathrm{x}$ & $\mathrm{x}$ & $\mathrm{x}$ & $\mathrm{x}$ & $\mathrm{x}$ & $\mathrm{x}$ & $\mathrm{x}$ \\
\hline Ludolf Volemont & Organ tuner & $\mathrm{x}$ & $\mathrm{x}$ & $\mathrm{x}$ & $\mathrm{x}$ & & & \\
\hline Hendrich Van Voerste & Organ tuner and blower & & & & & $\mathrm{x}$ & $\mathrm{x}$ & $\mathrm{x}$ \\
\hline Corneille Zuane & Furrier & $\mathrm{x}$ & & & & & & \\
\hline Gregorio le Pesquier & Furrier & & $\mathrm{x}$ & $\mathrm{x}$ & $\mathrm{x}$ & $\mathrm{x}$ & & \\
\hline Henry Martin & $\begin{array}{l}\text { Moço de capilla } \\
\text { /Furrier }\end{array}$ & $\mathrm{x}$ & $\mathrm{x}$ & $\mathrm{x}$ & $\mathrm{x}$ & $\mathrm{x}$ & $\mathrm{x}$ & $\mathrm{x}$ \\
\hline François Simon & $\begin{array}{l}\text { Moço de capilla } \\
\text { /Latin master }\end{array}$ & $\mathrm{x}$ & $\mathrm{x}$ & $\mathrm{x}$ & $\mathrm{x}$ & $\mathrm{x}$ & $x$ & $\mathrm{x}$ \\
\hline Pasquier Regnart & Moço de capilla & & & & & & $\mathrm{x}$ & $\mathrm{x}$ \\
\hline Pierre de Bablincourt & Moço de capilla & & & & & & $\mathrm{x}$ & $\mathrm{x}$ \\
\hline $\begin{array}{l}\text { Mathias Manort (Maneel) } \\
\text { François Loquemberg } \\
\text { George Pesqueur }\end{array}$ & $\begin{array}{l}\text { Moço de oratorio } \\
\text { Moço de oratorio } \\
\text { Moço de limosna }\end{array}$ & $\begin{array}{l}\mathrm{x} \\
\mathrm{x} \\
\mathrm{x}\end{array}$ & {$[\mathrm{x}]$} & {$[\mathrm{x}]$} & {$[\mathrm{x}]$} & $\mathrm{x}$ & $\mathrm{x}$ & $\mathrm{x}$ \\
\hline Pompeyo de Rusy & Copyist & & & & & & $\mathrm{x}$ & $\mathrm{x}$ \\
\hline
\end{tabular}




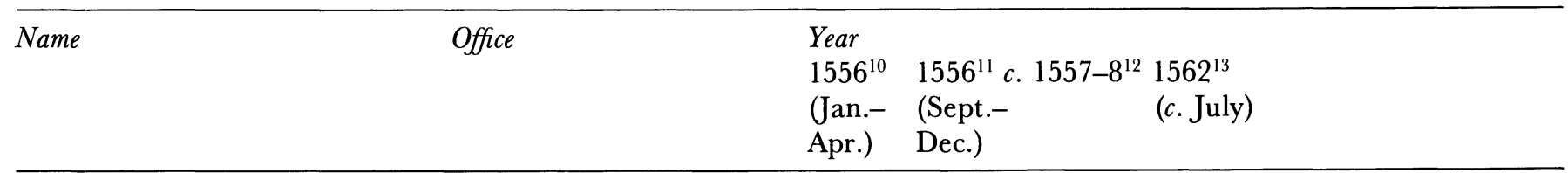

\section{Capilla}

Pedro de Castro

(Bishop of Cuenca)

[Gaspar de Zúñiga y

Avellaneda (Archbishop of Santiago) ${ }^{14}$

Lupercio de Quiñones

[Antón Bravo ${ }^{15}$

Hernando Enríquez

Alonso de Castro

Bartolomé de Miranda

[(unnamed)

\section{Spanish Chaplains}

Francisco de Portugalete

Francisco de Barrio

Joan de Angulo

Diego Suárez

Pero Sánchez de Arellano

Dr Goz Mediano
Capellan mayor

Capellan mayor

Limosnero mayor

Sacristan mayor

Sumiller de oratorio

Franciscan preacher

Dominican preacher

Receptor ${ }^{16}$
(x) $[\mathrm{x}] \quad[\mathrm{x}]$
$\left.\mathrm{x} \quad\left(\mathrm{x}^{?}\right)\right]$

$\mathrm{x}$

$\mathrm{x}]$

$\mathrm{x}$

$\mathrm{x}$

$\mathrm{x}$

$\mathrm{x}]$

$\begin{array}{llll}(4-5) & {[5]} & (10-14) & (3) \\ \mathrm{x} & {[\mathrm{x}]} & \mathrm{x} & \\ \mathrm{x} & {[\mathrm{x}]} & \mathrm{x} & \mathrm{x} \\ \mathrm{x} & {[\mathrm{x}]} & \mathrm{x} & \mathrm{x} \\ (\mathrm{x}) & {[\mathrm{x}]} & \mathrm{x} & \\ \mathrm{x} & {[\mathrm{x}]} & \mathrm{x} & \\ & & \mathrm{x} & \end{array}$




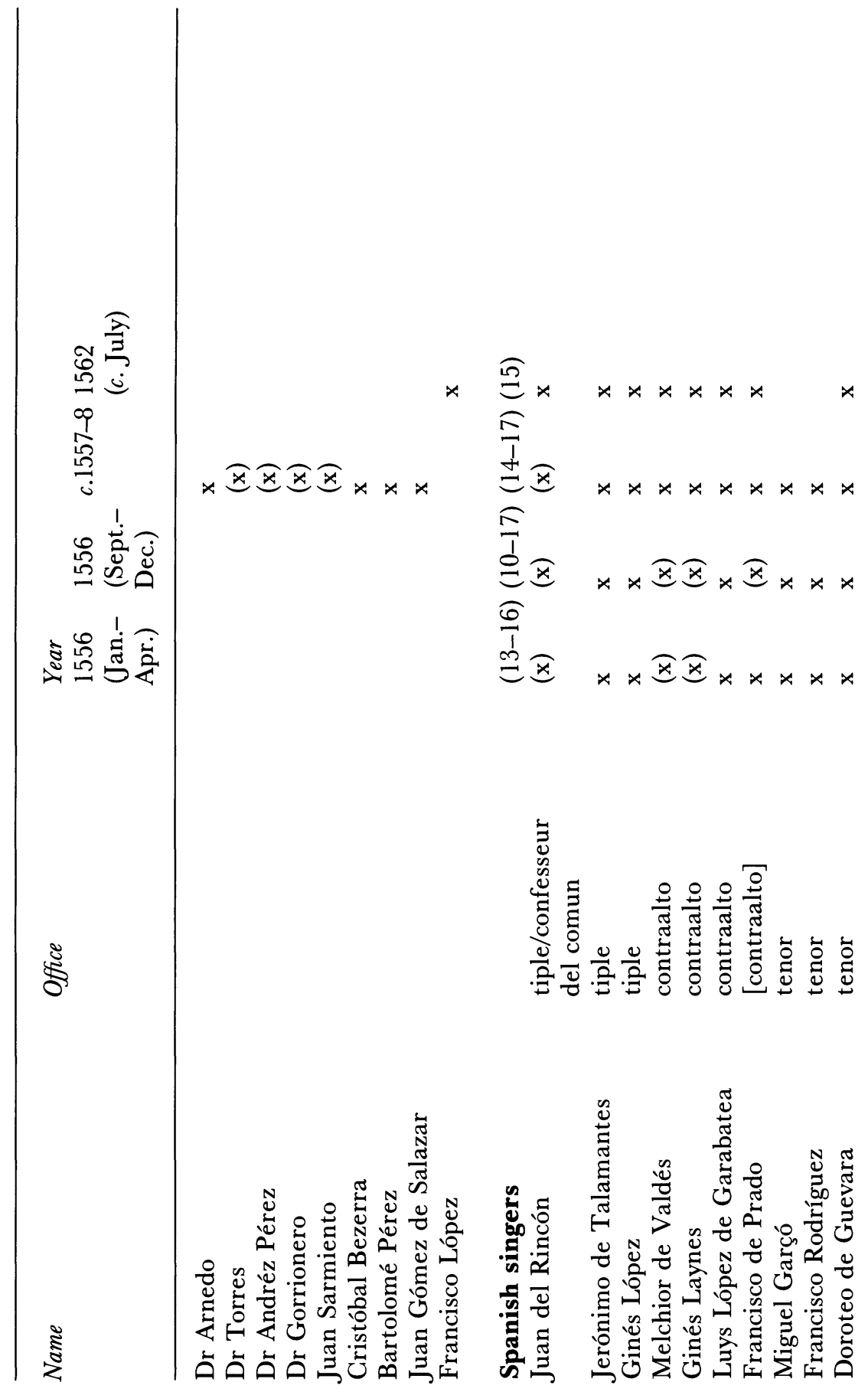




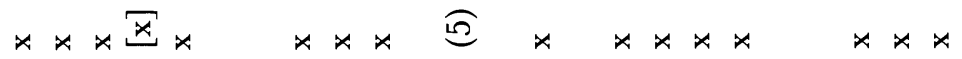

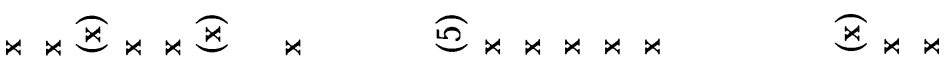

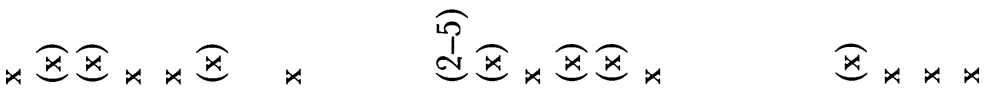

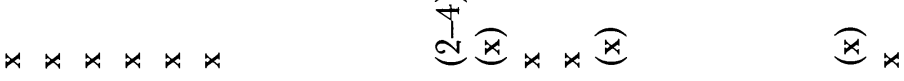

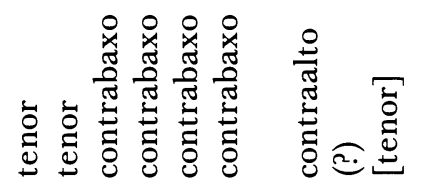

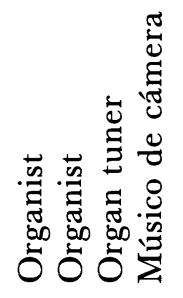

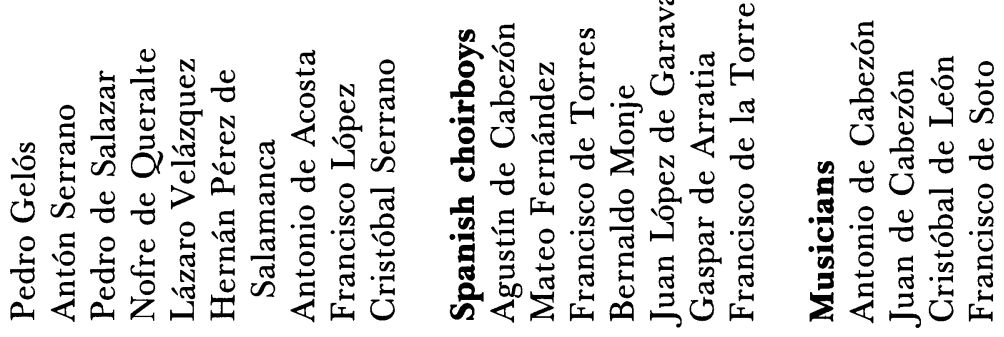




\begin{tabular}{lllll}
\hline Name & Office & Year & & \\
& 1556 & 1556 & $c .1557-8$ & 1562 \\
& & (Jan.- & (Sept.- & (c. July) \\
& Apr.) & Dec.) & &
\end{tabular}

\section{Other officers}

[unnamed]

[unnamed]

Alonso de Almarez

Juan de Arce (Arze)

Simón Rodríguez

Francisco de Almaraz

Cristóbal Ruiz

Juan de Quizedo

Iñigo de Santacruz
Moço de capilla

Moço de capilla

Moço de capilla

Moço de capilla

Moço de capilla

Moço de capilla

Moço de capilla

Moço de limosna

Furrier $\mathrm{x}$

$\mathrm{x}$

1 The spellings of the names on this table are usually derived from the first source listed here in which they appear; these may vary considerably in presentation between the sources. Unfortunately, there are lacunae in the surviving royal chapel documents, which explains why some years are not represented on this table. Only the names of instrumentalists of 1556 are available in the secondary sources; these have been omitted in this table. For details, and the names of the trumpeters, drummers and players of the vihuelas de arco in 1556, see Anglés, La música en la Corte de Carlos V, pp. 139-40; Robledo, 'La música en la corte Madrileña', pp. 786-7 and 789; and Vander Straeten, La Musique aux Pays-Bas, vii, pp. 359-60.

Indications of membership in round brackets $(x)$ denote absences from court and in square brackets [x] where a name is omitted in a document (which might also indicate absence).

$2 *=$ 'Chantres venutz nuvellement de Flandres' (1561); Vander Straeten, La Musique aux Pays-Bas, viii, pp. 42-3.

3 Robledo, 'La música en la corte Madrileña', pp. 786-7, and Vander Straeten, La Musique aux Pays-Bas, vii, pp. 359-60.

4 Vigili Blanquet, 'La capilla musical', pp. 275-6.
1556
(Sept.-

\section{July)}

$\mathbf{x}$

$\begin{array}{ll}\mathbf{x} & \mathbf{x} \\ \mathbf{x} & \mathbf{x} \\ \mathbf{x} & \mathbf{x} \\ \mathbf{x} & \\ \mathbf{x} & \\ \mathbf{x} & \\ \mathbf{x} & \end{array}$

5 Vander Straeten, La Musique aux Pays-Bas, viii, p. 16.

6 Ibid., p. 25.

7 Ibid., pp. 30-1. See also Robledo, 'La música en la corte Madrileña', pp. 788-90.

8 Ibid., pp. 40-1, and Vigili Blanquet, 'La capilla musical', pp. 276-9.

9 Vander Straeten, La Musique aux Pays-Bas, viii, pp. 41-2.

10 Anglés, La música en la Corte, p. 137.

11 Ibid., pp. 138-40, and Robledo, 'La música en la corte Madrileña', pp. 787-8.

12 Vigili Blanquet, 'La capilla musical', pp. 273-5.

13 Ibid., pp. 277-9.

15 Antón Bravo entered the Spanish Capilla at an unspecified date in 1559 remaining until his death in 1576 (E-Sag, Casas y Situos Reales, leg. 82). I would like to thank Luis Robledo for providing me with this information.

16 A receptor is mentioned in a document dating from 1562. See Barbieri papers 2 , doc. $156[\mathrm{a}]$. 